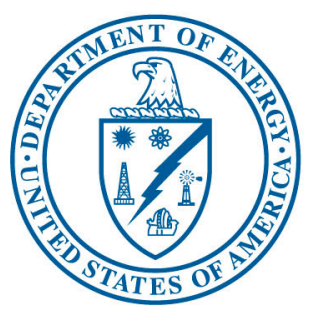

U.S. Department of Energy

Idaho Operations Office

\title{
Idaho National Laboratory Site Environmental Monitoring Plan
}

February 2014 
DOE/ID-11088

Rev. 4

\section{Idaho National Laboratory Site Environmental Monitoring Plan}

February 2014

Prepared for the

U.S. Department of Energy

DOE Idaho Operations Office 


\section{DISCLAIMER}

This information was prepared as an account of work sponsored by an agency of the U.S. Government. Neither the U.S. Government nor any agency thereof, nor any of their employees, makes any warranty, expressed or implied, or assumes any legal liability or responsibility for the accuracy, completeness, or usefulness, of any information, apparatus, product, or process disclosed, or represents that its use would not infringe privately owned rights. References herein to any specific commercial product, process, or service by trade name, trade mark, manufacturer, or otherwise, do not necessarily constitute or imply its endorsement, recommendation, or favoring by the U.S. Government or any agency thereof. The views and opinions of authors expressed herein do not necessarily state or reflect those of the U.S. Government or any agency thereof. 
This page intentionally left blank. 


\section{EXECUTIVE SUMMARY}

The Idaho National Laboratory (INL) Site consists of nine major facilities located in southeastern Idaho within a U.S. Department of Energy (DOE) specified boundary and several laboratories and administrative buildings located in Idaho Falls, Idaho, approximately $48 \mathrm{~km}(30 \mathrm{mi})$ east of the INL Site boundary. This plan describes routine environmental compliance and surveillance monitoring of airborne and liquid effluents, and ecological and meteorological conditions on and in the vicinity of the INL Site.

Environmental monitoring discussed in this plan is conducted in accordance with DOE Order 458.1, Radiation Protection of the Public and the Environment ${ }^{1}$. The purpose of DOE Order 458.1 is to establish requirements to protect the public and the environment against undue risk from radiation associated with radiological activities conducted under the control of DOE pursuant to the Atomic Energy Act of 1954, as amended. The objectives of the order include 1) conducting DOE radiological activities so that exposure to members of the public is maintained within the dose limits established in the order, 2) controlling radiological clearance of DOE real and personal property, 3) ensuring that potential radiation exposures to members of the public are as low as reasonably achievable, 4) ensuring DOE sites have the capabilities, consistent with the types of radiological activities conducted, to monitor routine and non-routine radiological releases and to assess the radiation doses to members of the public, and 5) protecting the environment from the effects of radiation and radioactive material.

This plan includes the rationale for monitoring, the types of media monitored, where the monitoring is conducted, and information regarding access to analytical results. Environmental monitoring activities are conducted by a variety of organizations consisting of:

- Idaho National Laboratory

- Idaho Cleanup Project

- Environmental Surveillance, Education, and Research Program

- $\quad$ United States Geological Survey

- National Oceanic and Atmospheric Administration

- $\quad$ Advanced Mixed Waste Treatment Project.

Monitoring of airborne and liquid effluents is performed to verify compliance with permitting requirements, state and federal regulations, and environmental protection policies and commitments. Surveillance monitoring addressed in this document is driven by DOE order and is performed to characterize pre-operational conditions, detect, characterize, and respond to releases from site operations and activities, assess impacts, estimate dispersal patterns in the environment, characterize the exposures and doses to individuals and the population, and evaluate the potential impacts to biota in the vicinity of the release.

Nonroutine activities, such as special research studies and the characterization of individual sites for environmental restoration, are outside the scope of this plan. Environmental monitoring activities at Naval Reactors Facility 
conducted by Bechtel Marine Propulsion Corporation are not included in this plan. 
This page intentionally left blank. 


\section{CONTENTS}

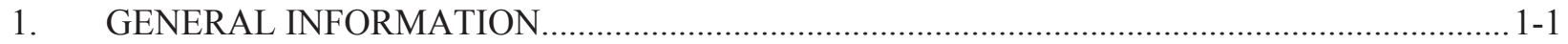

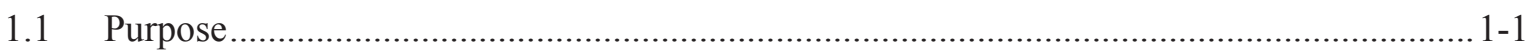

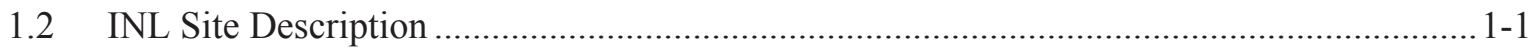

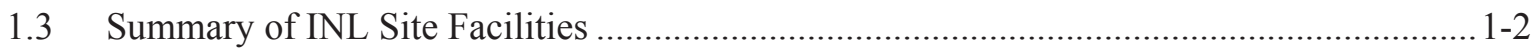

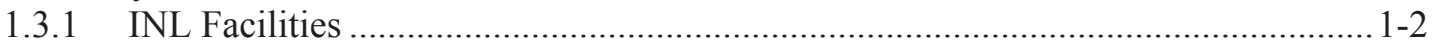

1.3.2 Idaho Cleanup Project Facilities ................................................................... 1-5

1.3.3 Advanced Mixed Waste Treatment Project Facility .............................................. 1-5

1.3.4 Naval Reactors Facility ............................................................................... 1-6

1.3.5 Radiological and Environmental Sciences Laboratory (RESL) ............................. 1-6

2. INL SITE ENVIRONMENTAL MONITORING OVERVIEW ...............................................2-1

2.1 History of Environmental Monitoring at the INL ......................................................... 2-2

2.2 Environmental Monitoring Organizations ................................................................ 2-4

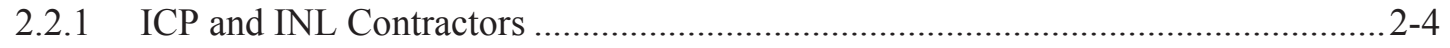

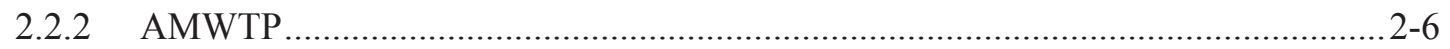

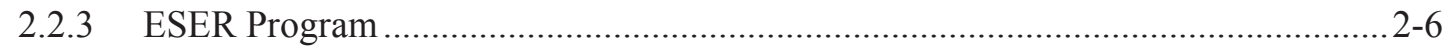

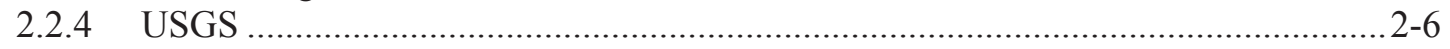

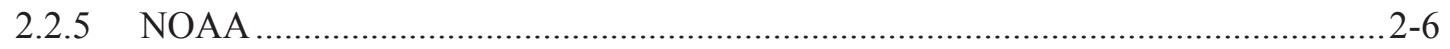

2.2.6 Idaho Environmental Monitoring Program ......................................................... 2-7

2.3 Laboratory-wide Monitoring Committees .................................................................... 2-7

2.3.1 Monitoring and Surveillance Committee and Groups............................................2-7

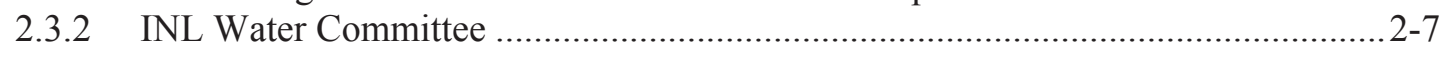

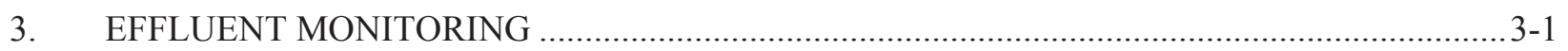

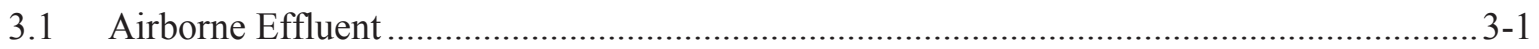

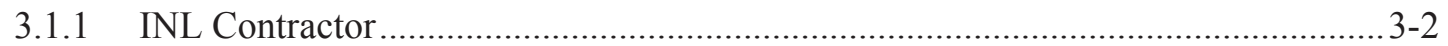

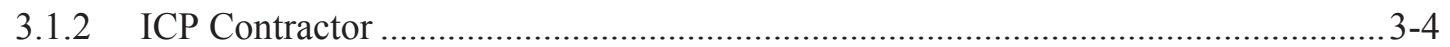

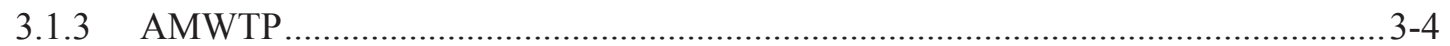

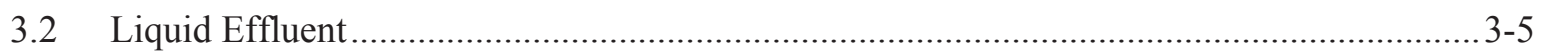

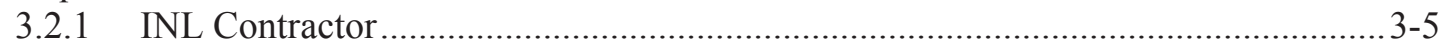

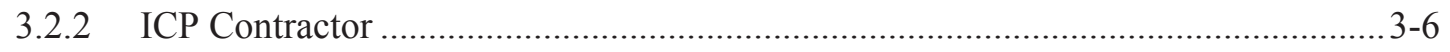

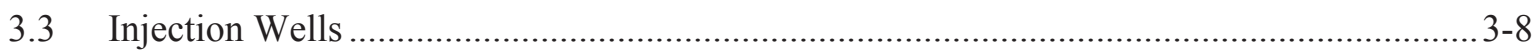

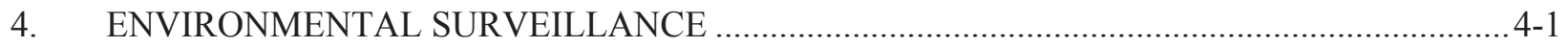

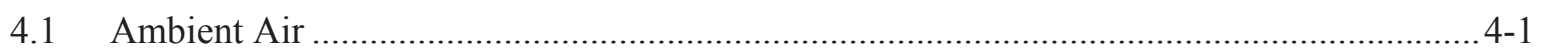

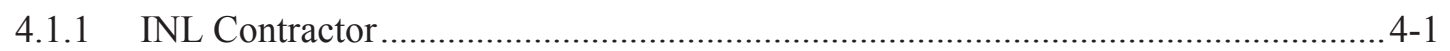

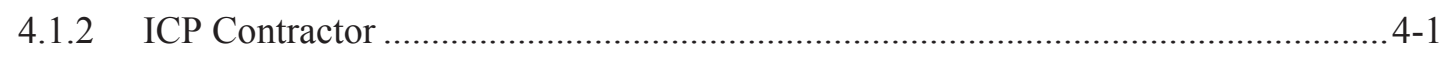

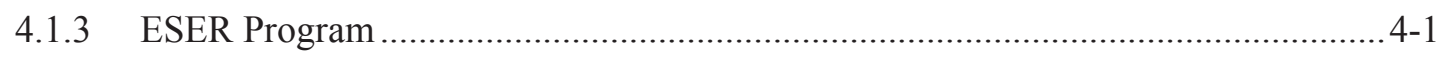

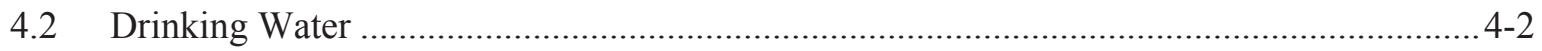

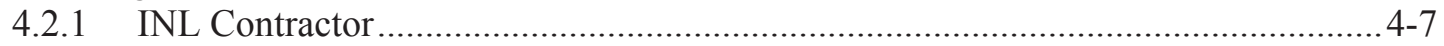

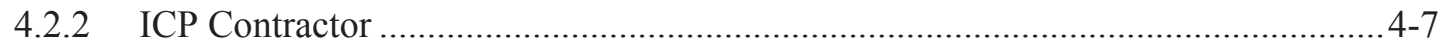

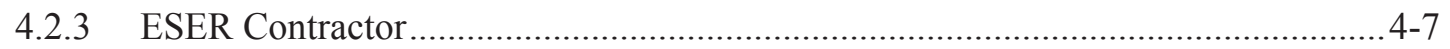

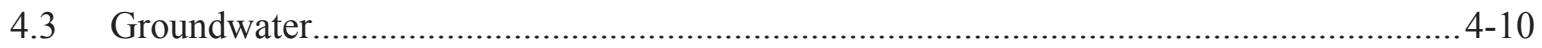

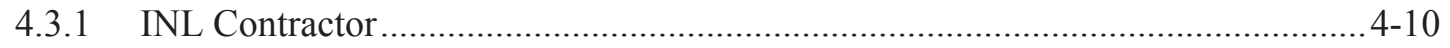

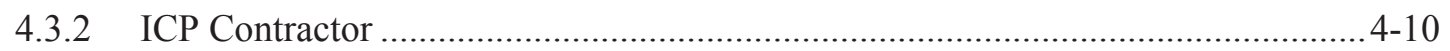

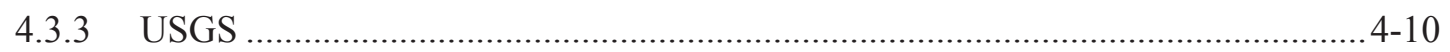

vi Contents 


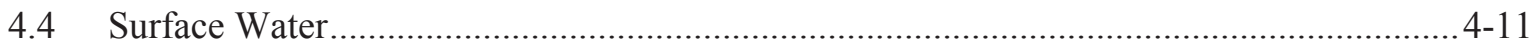

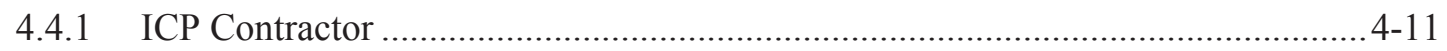

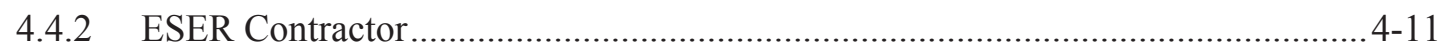

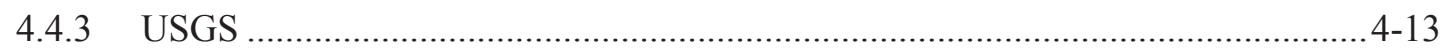

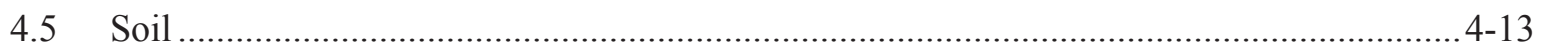

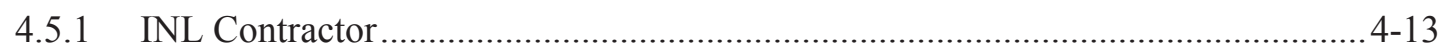

4.5.2 ICP Contractor ........................................................................... 4 - 13

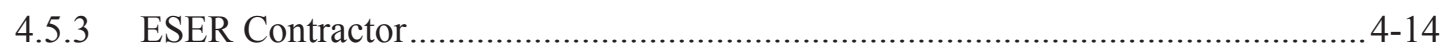

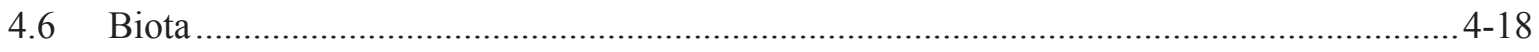

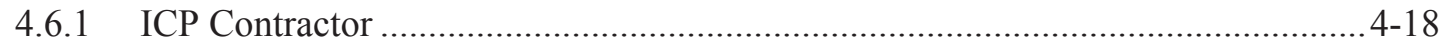

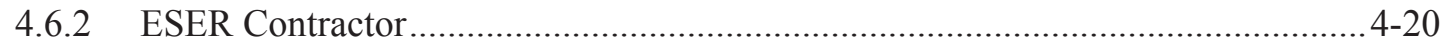

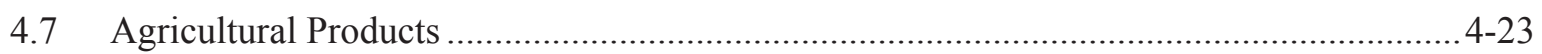

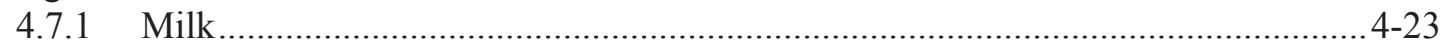

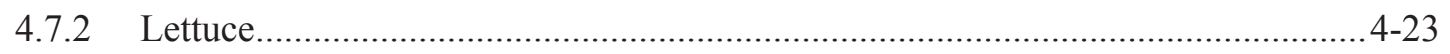

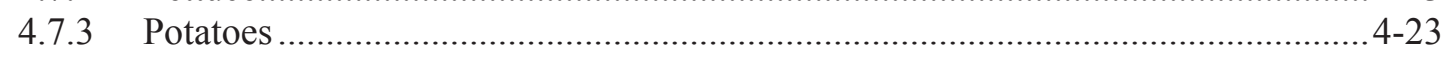

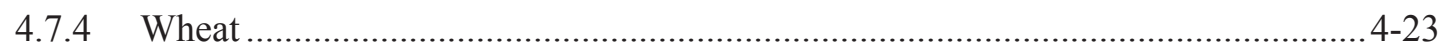

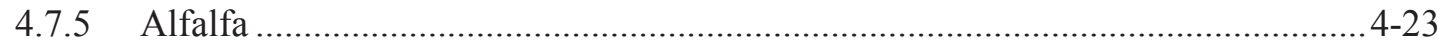

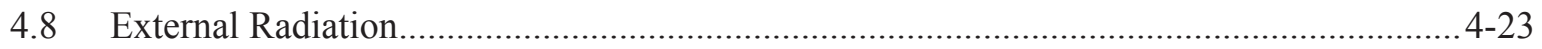

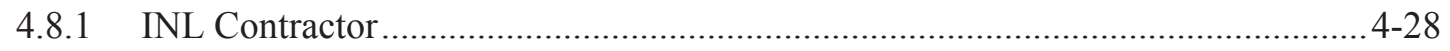

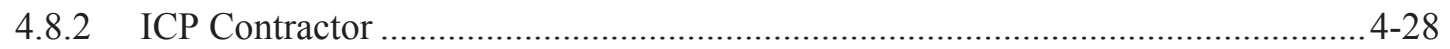

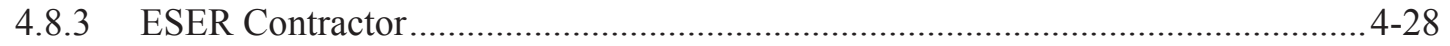

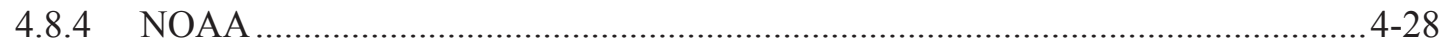

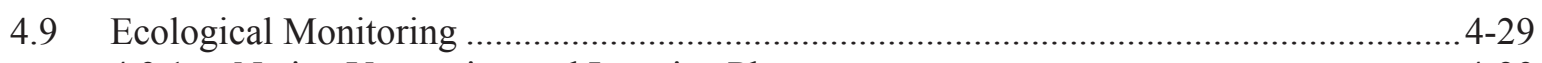

4.9.1 Native Vegetation and Invasive Plants ........................................................... 4-29

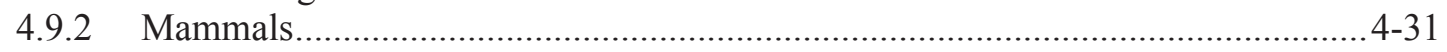

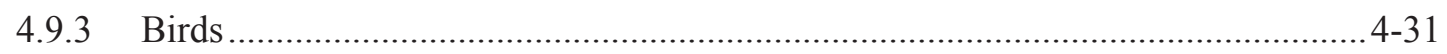

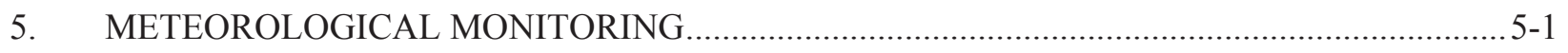

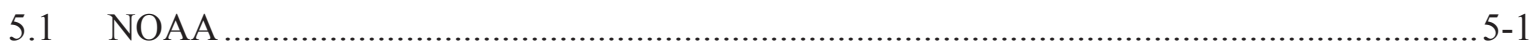

6. ENVIRONMENTAL EVENT MONITORING ...................................................................... $6-1$

6.1 Response to an Emergency or Unplanned Release ...................................................... 6-1

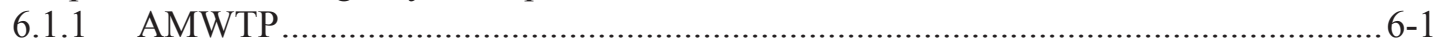

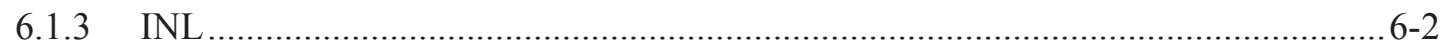

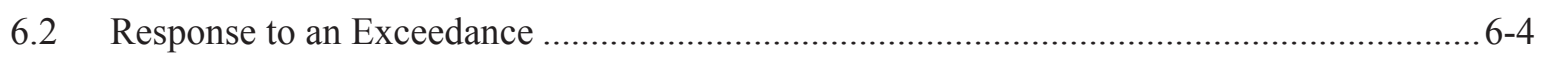

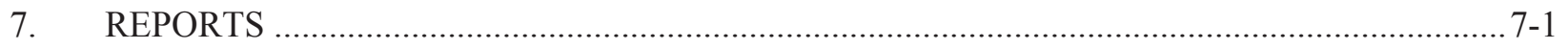

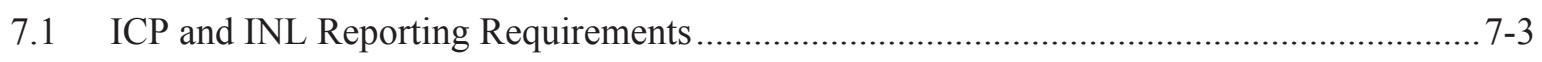

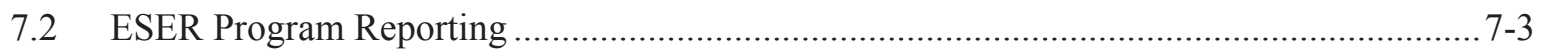

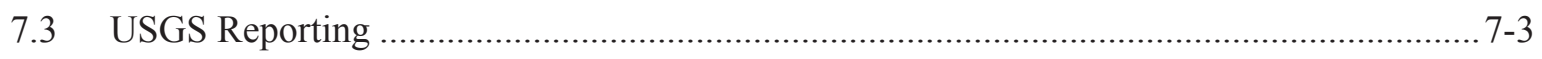

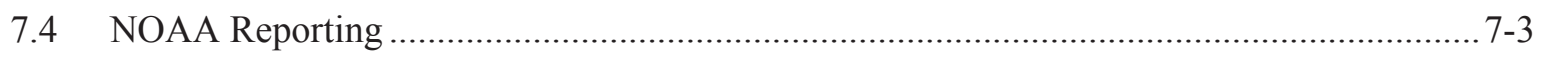

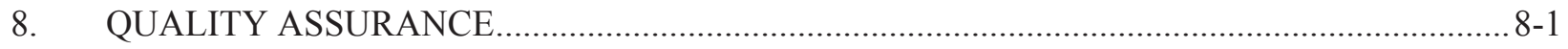

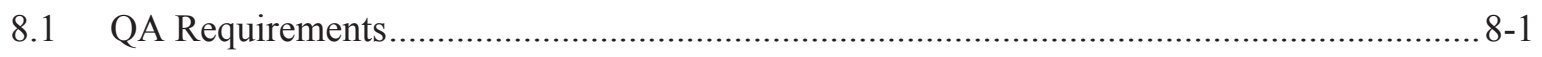

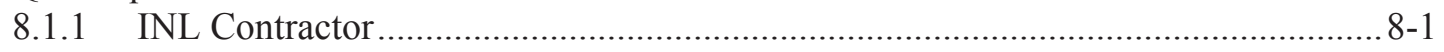

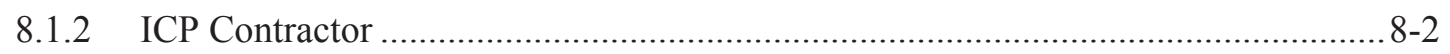

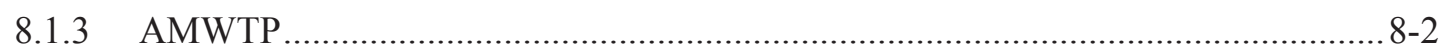

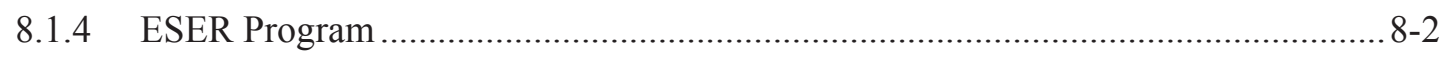




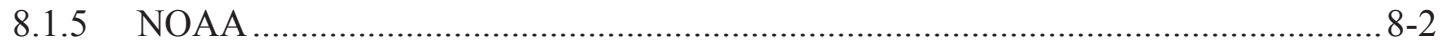

8.2 Sample and Analysis Management Activities.............................................................. 8-2

9. RADIOLOGICAL DOSE EVALUATION ........................................................................

9.1 Maximum Individual Dose_-Airborne Emissions Pathway ............................................... 9-1

9.1.1 Dose Evaluation Using CAP-88 Computer Code ...................................................9-1

9.1.2 Dose Evaluation Using MDIFF Dispersion Model...............................................9-1

9.2 80-Kilometer (50-Mile) Population Dose ....................................................................... 9-2

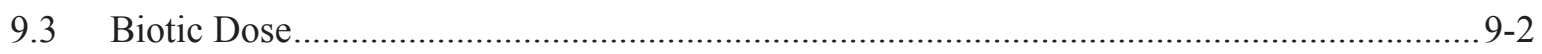

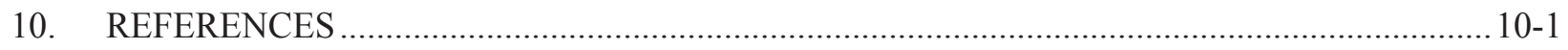

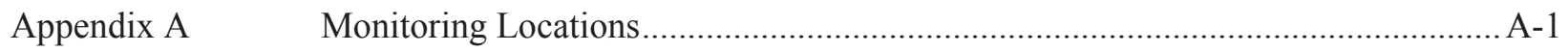

\section{FIGURES}

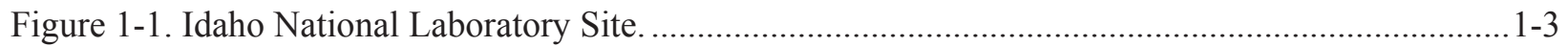

Figure 1-2. Idaho National Laboratory Site in relation to the Snake River Plain Aquifer........................1-4

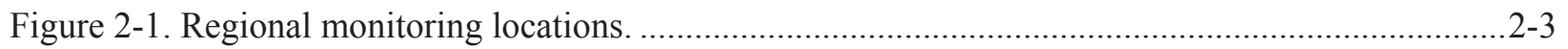

Figure 3-1. Airborne effluent monitoring locations...............................................................................

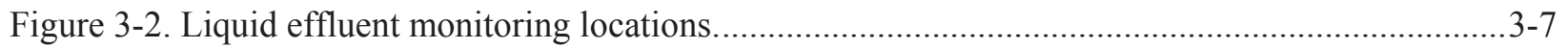

Figure 3-3. Storm water injection well basin monitoring locations...................................................... 3-9

Figure 4-1. Regional ambient air monitoring locations. ....................................................................

Figure 4-2. Detailed on-Site ambient air monitoring locations...........................................................4-4

Figure 4-3. Atmospheric moisture monitoring locations. ................................................................... $4-5$

Figure 4-4. Precipitation monitoring locations. ............................................................................... $4-6$

Figure 4-5. Regional drinking water monitoring locations................................................................ $4-8$

Figure 4-6. Detailed on-Site drinking water monitoring locations. ....................................................... 4-9

Figure 4-7. Regional surface water monitoring locations................................................................. $4-12$

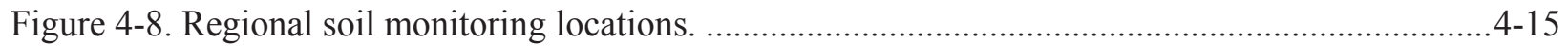

Figure 4-9. Detailed on-Site soil monitoring locations......................................................................16

Figure 4-10. Soil gas and soil moisture monitoring locations. .......................................................... $4-17$

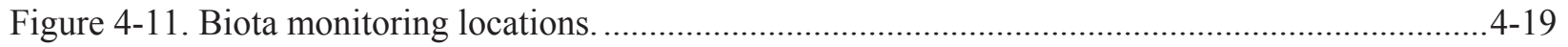

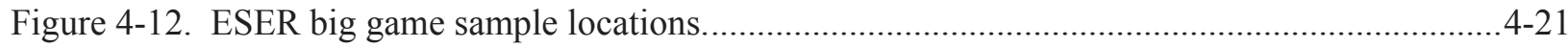

Figure 4-13. Flora and fauna monitoring locations...................................................................... $4-22$

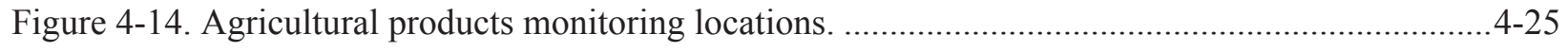

Figure 4-15. Regional external radiation monitoring locations. ....................................................... 4-26

Figure 4-16. Detailed on-Site external radiation monitoring locations..............................................4-27

Figure 4-17. ESER Program ecological monitoring locations...........................................................4-30 


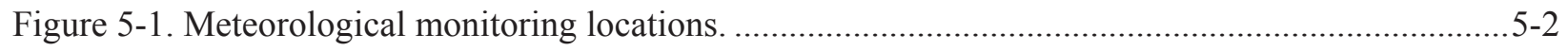

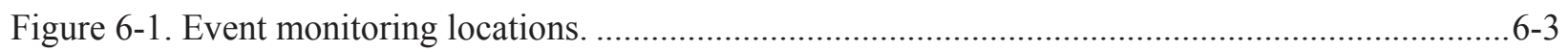

\section{TABLES}

Table 2-1. Summary of INL Site environmental monitoring organization activities. ............................2-5

Table 7-1. Effluent monitoring and environmental monitoring reports at the INL Site. .........................7-2

Table A-1. Airborne Effluent Monitoring Locations...............................................................................

Table A-2. Soil Gas and Soil Moisture Surveillance Locations. .............................................................

Table A-3. Atmospheric Moisture Surveillance Locations.................................................................... A-7

Table A-4. Liquid Effluent Monitoring Locations...............................................................................

Table A-5. Stormwater Effluent Monitoring Locations......................................................................... A-9

Table A-6. Ambient Air Surveillance Locations. .......................................................................... A-10

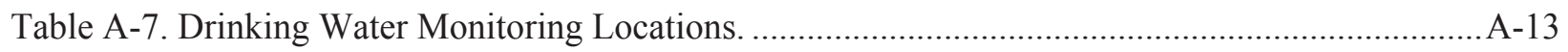

Table A-8. Surface Water Surveillance Locations..............................................................................

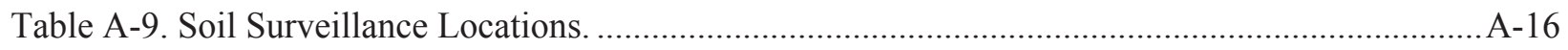

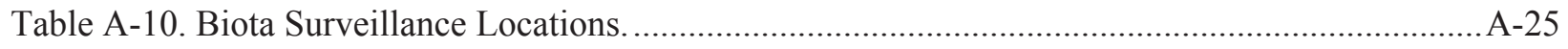

Table A-11. Agricultural Products Surveillance Locations...................................................................26

Table A-12. External Radiation Surveillance Locations.......................................................................

Table A-13. Flora and Fauna Surveillance Locations...........................................................................33

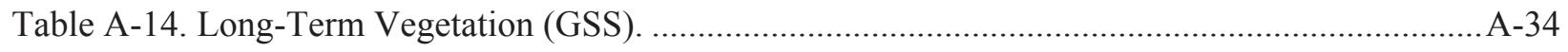

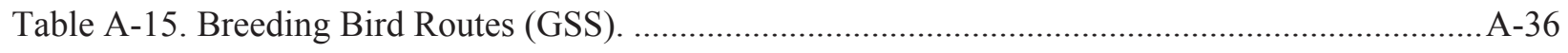

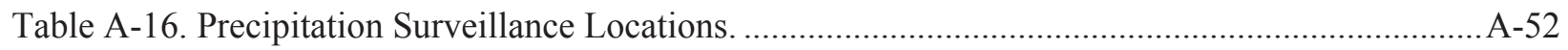

Table A-17. Meteorological Monitoring Locations..............................................................................

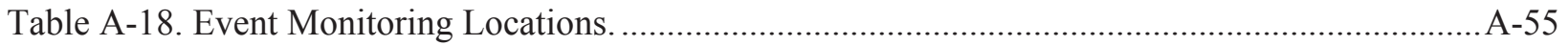




\section{ACRONYMS}

AMWTP

ARLFRD

ARP

ASER

ASME

ATR

BEA

BBS

BLR

CERCLA

CFA

CITRC

CFR

CRMO

CRWG

CWI

DEQ

DOE

DOE-ID

ESRPA

EBR

EDE

EMS

EOC

EPA

ESA

ESER

ES\&S

GPRS

GSS

HSL

ICDF

ICP

IDAPA

IEMP
Advanced Mixed Waste Treatment Project

Air Resources Laboratory Field Research Division

Accelerated Retrieval Project

Annual Site Environmental Report

American Society of Mechanical Engineers

Advanced Test Reactor

Battelle Energy Alliance

Breeding Bird Survey

Big Lost River

Comprehensive Environmental Response, Compensation, and Liability Act

Central Facilities Area

Critical Infrastructure Test Range Complex

Code of Federal Regulations

Cultural Resources Management Office

Cultural Resources Working Group

CH2M-WG Idaho, LLC

Idaho Department of Environmental Quality

Department of Energy

Department of Energy Idaho Operations Office

Eastern Snake River Plain Aquifer

Experimental Breeder Reactor

effective dose equivalent

Environmental Management System

Emergency Operations Center

Environmental Protection Agency

Endangered Species Act

Environmental Surveillance, Education and Research (Program)

Environmental Support and Services

global positioning radiometric scanner

Gonzales-Stoller Surveillance

Health Services Laboratory

Idaho CERCLA Disposal Facility

Idaho Cleanup Project

Idaho Administrative Procedures Act

Idaho Environmental Monitoring Program 
INEEL

INEL

INL

INTEC

IRC

ITG

IWTU

$\mathrm{M} \& \mathrm{O}$

MDIFF

MEI

MFC

MSC

NESHAP

NOAA

NRF

OSLD

QA

R\&D

RCRA

REC

RESL

RI/FS

ROD

RWMC

SDA

SMC

STP

TAN

TLD

USGS

USGS-BRD

WAG

WIPP

WNS

WRP

WRRTF
Idaho National Engineering and Environmental Laboratory

Idaho National Engineering Laboratory

Idaho National Laboratory

Idaho Nuclear Technology and Engineering Center

INL Research Center

Idaho Treatment Group, LLC

Integrated Waste Treatment Unit

management and operating

mesoscale diffusion

maximally exposed individual

Materials and Fuels Complex

Monitoring and Surveillance Committee

National Emission Standards for Hazardous Air Pollutants

National Oceanic and Atmospheric Administration

Naval Reactors Facility

optically stimulated luminescent dosimeter

quality assurance

research and development

Resource Conservation and Recovery Act

Research and Education Campus

Radiological and Environmental Sciences Laboratory

Remedial Investigation/Feasibility Study

Record of Decision

Radioactive Waste Management Complex

Subsurface Disposal Area

Specific Manufacturing Capability

Sewage Treatment Plant

Test Area North

thermoluminescent dosimeter

United States Geological Survey

United States Geological Survey-Biological Resources Division

Waste Area Group

Waste Isolation Pilot Plant

White-nose syndrome

Wastewater Reuse Permit

Water Reactor Research Test Facility 


\section{Idaho National Laboratory Environmental Monitoring Plan}

\section{GENERAL INFORMATION}

\subsection{Purpose}

This plan provides a high-level summary of environmental monitoring performed by various organizations within and around the Idaho National Laboratory (INL) Site as required by U.S. Department of Energy (DOE) Order 435.1, "Radioactive Waste Management" and DOE Order 458.1, "Radiation Protection of the Public and the Environment"l, Guide DOE/EH-0173T, "Environmental Regulatory Guide for Radiological Effluent Monitoring and Surveillance", and in accordance with 40 Code of Federal Regulations (CFR) 61, "National Emission Standards for Hazardous Air Pollutants"5. The purpose of these orders is to 1) implement sound stewardship practices that protect the air, water, land, and other natural and cultural resources that may be impacted by DOE operations, and 2) to establish standards and requirements for the operations of DOE and DOE contractors with respect to protection of the environment and members of the public against undue risk from radiation. This plan describes the organizations responsible for conducting environmental monitoring across the INL Site, the rationale for monitoring, the types of media being monitored, where the monitoring is conducted, and where monitoring results can be obtained.

Detailed monitoring procedures, program plans, or other governing documents used by contractors or agencies to implement requirements are referenced in this plan. This plan covers all planned monitoring and environmental surveillance. Nonroutine activities such as special research studies and characterization of individual sites for environmental restoration are outside the scope of this plan.

\subsection{INL Site Description}

The INL Site is approximately 230,500 hectares $\left(890 \mathrm{mi}^{2}\right)$ and is located on the Eastern Snake River Plain in southeastern Idaho (see Figure 1-1). It was established as a nuclear energy research and development (R\&D) testing station in the late 1940s and was designated a National Environmental Research Park in 1975. All land within the Site is protected as an outdoor laboratory where the effects of energy development, industrial activities on the environment, and the complex ecological relationships of this cool desert ecosystem can be studied. The INL Site is owned by DOE and administered through its Idaho Operations Office (DOE-ID). The DOE-ID oversees operations at the INL Site.

Subsurface geology consists of successive layers of basalt and sedimentary strata, overlain by windand water-deposited sediments. Most of the Site is in the closed Mud Lake-Lost River drainage basin, which has been informally named the Pioneer Basin. Surface waters within the Pioneer Basin include the Big Lost River, the Little Lost River, and Birch Creek drainages which drain mountain watersheds located to the north and northwest of the Site. All three drainages may flow onto the Site during high flow years but are otherwise ephemeral. In addition, local rainfall and snowmelt contribute to surface water, mainly during the spring. The portion of surface water that is not lost to evapotranspiration infiltrates into the subsurface. Both aquifer and surface waters are used for irrigating crops and other applications outside the Site.

The primary groundwater source of the region is the Eastern Snake River Plain Aquifer (ESRPA) (Figure 1-2). The ESRPA is approximately $320 \mathrm{~km}$ (199 mi) long, 30 to $100 \mathrm{~km}$ (20 to $60 \mathrm{mi}$ ) wide, and encompasses an area of about 2,500,000 hectares $\left(9,650 \mathrm{mi}^{2}\right)$. This sole-source aquifer is one of the most productive in the U.S, is a source of process and drinking water to more than 200,000 people, and supplies irrigation water to a large, regional agricultural and aquaculture economy. 
The depth to the ESRPA varies from approximately $60 \mathrm{~m}(200 \mathrm{ft})$ in the northern part of the INL Site to more than $270 \mathrm{~m}(900 \mathrm{ft})$ in the southern part. The aquifer is recharged from infiltrating precipitation and irrigation seepage, runoff from the surrounding highlands, and groundwater underflows from the surrounding watersheds. Groundwater in the ESRPA flows generally to the southwest, although locally the direction of flow is influenced by recharge from rivers, surface water, spreading areas, and heterogeneities in the aquifer. Groundwater flow rates in the vicinity of the INL Site range from approximately 1.5 to $6 \mathrm{~m}$ ( 5 to $20 \mathrm{ft})$ per day.

Annual rainfall at the Site is light, and the region is classified as arid to semiarid. ${ }^{7}$ The long-term average (from March 1950 through 2005) annual precipitation at the Site is $21.6 \mathrm{~cm}$ (8.5 in. at the Central Facilities Area ([CFA) station). Monthly precipitation is usually highest in April, May, and June and lowest in July and October. The average daily temperature is $17.1^{\circ} \mathrm{C}\left(62.7^{\circ} \mathrm{F}\right)$ in the summer, and the average daily minimum temperature is $-5.5^{\circ} \mathrm{C}\left(22.1^{\circ} \mathrm{F}\right)$ in the winter. The Site is in the belt of prevailing westerly winds, which are channeled within the plain to produce a west-southeasterly or southwesterly wind at most locations on the Site.

\subsection{Summary of INL Site Facilities}

The INL Site consists of nine major facilities and several laboratories and administrative buildings located approximately $48 \mathrm{~km}(30 \mathrm{mi})$ east of the Site boundary in Idaho Falls, Idaho. Battelle Energy Alliance, LLC (BEA) is the management and operating (M\&O) contractor for the INL. In this document, BEA is referred to as the INL contractor. CH2M-WG Idaho, LLC (CWI) is the Idaho Cleanup Project (ICP) contractor and is referred to as the ICP contractor. The Advanced Mixed Waste Treatment Project (AMWTP) contractor is Idaho Treatment Group, LLC (ITG).

\subsubsection{INL Facilities}

The CFA houses many technical and support services for the INL contractor including administrative offices, monitoring and calibration laboratories, fire protection, medical services, warehouses, vehicle and equipment pools, and bus operations.

The Research and Education Campus (REC) in Idaho Falls consists of office and classroom complexes and multiple laboratory facilities, including many one-of-a-kind advanced labs dedicated to the full spectrum of physical and life science research. The laboratories are "modular," with respect to their provisions, for ease of utility tailoring and flexibility. There are other advanced R\&D laboratories located in Idaho Falls, including engineering demonstration facilities, robotics laboratories, material research laboratories, and advanced information technology and computer simulation and modeling facilities.

The Materials and Fuels Complex (MFC) is the prime testing center in the U.S. for demonstration and proof-of-concept of nuclear energy technologies. Research and development activities at this facility are focused on areas of national concern, including energy, nuclear safety, spent nuclear fuel treatment, nonproliferation, decommissioning and decontamination technologies, nuclear material disposal, and homeland security. 


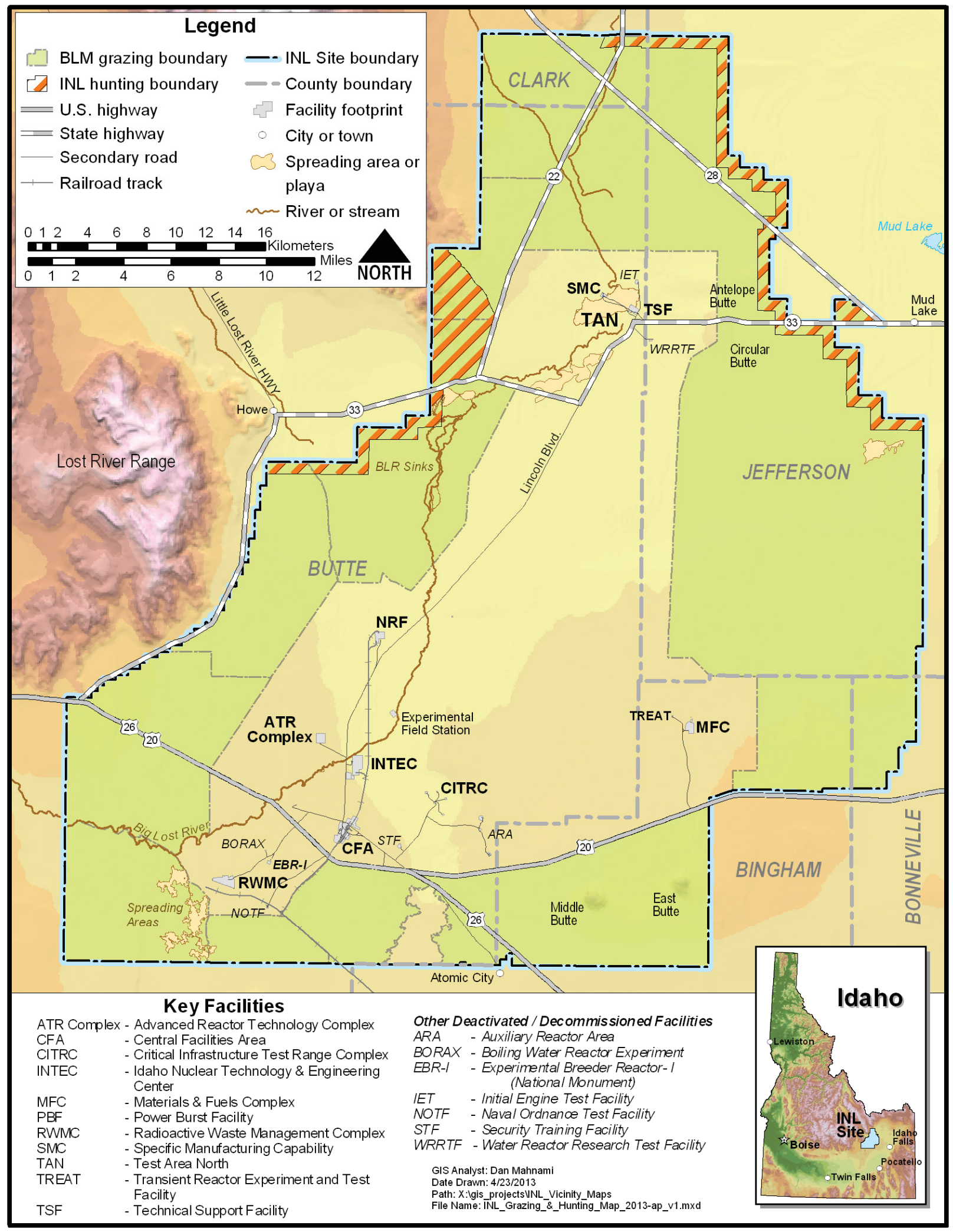

Figure 1-1. Idaho National Laboratory Site. 


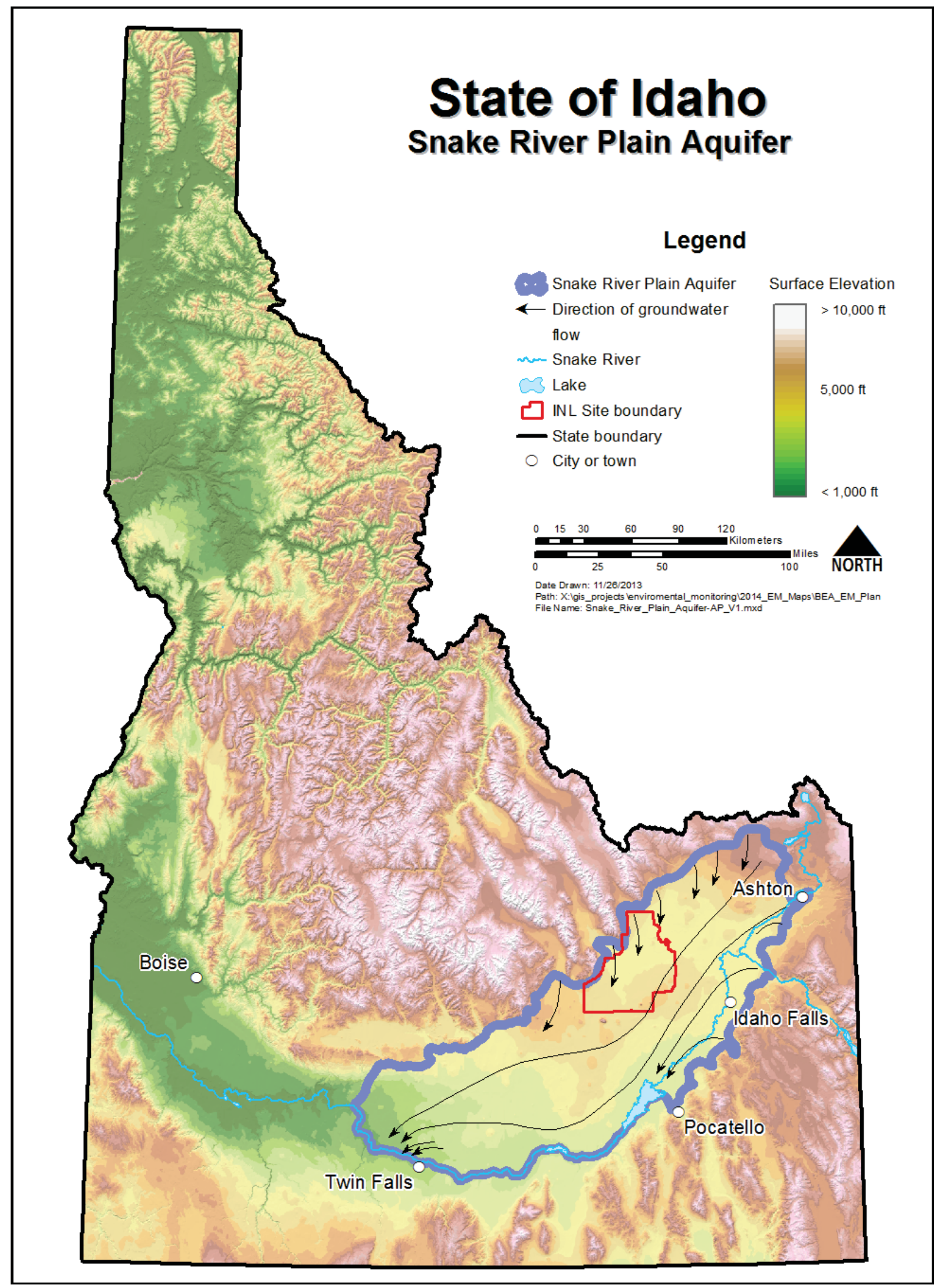

Figure 1-2. Idaho National Laboratory Site in relation to the Snake River Plain Aquifer. 
The Advanced Test Reactor Complex (ATR Complex) is the world's most sophisticated nuclear reactor testing complex and has extensive facilities for studying the effects of radiation on materials, testing nuclear fuels, and producing medical and industrial isotopes.

The Critical Infrastructure Test Range Complex (CITRC) is an isolated and secure microcosm of many of the critical infrastructure systems important to the operation of our country, including power, transportation, cyber, and communications. This INL facility was chosen to be a "Test Range" due to its remote location and dedication to various research, development, and testing activities.

The CITRC has a number of specific test beds (12 buildings, approximately $6,652 \mathrm{~m}^{2}\left[71,600 \mathrm{ft}^{2}\right]$, including the following:

- Range Support Area, which consists of office structures, training facility, area power substation, and area water supply system

- National Contraband Detection and Testing Center

- Incident Response Training and Testing Center, Range Control Center facility, and an office building housing the range director's office with other test bed facilities

- Special Programs test facility.

The Specific Manufacturing Capability (SMC) facility, located at Test Area North (TAN) houses a unique project that began with a Memorandum of Understanding between DOE and the U.S. Army in February 1985. Operated by the INL contractor, the SMC Project manufactures armor for the army's M1A2 Abrams battle tank.

\subsubsection{Idaho Cleanup Project Facilities}

The Idaho Nuclear Technology and Engineering Center (INTEC) was established in the 1950s to recover usable uranium in spent nuclear fuel from government reactors and to store spent nuclear fuel. The current work scope at INTEC includes removing excess nuclear material, closing radioactive and hazardous waste tanks, constructing the Integrated Waste Treatment Unit (IWTU) to prepare the liquid radioactive waste for shipment off-Site, transferring spent nuclear fuel from wet to dry storage, remediating the spent nuclear fuel basin, treating and disposing of waste, closing liquid waste tanks, remediating contaminated environmental sites, and demolishing facilities.

The Idaho CERCLA Disposal Facility (ICDF) is a landfill located just southeast of INTEC. It has been operating since 2003 to dispose of low-level waste and mixed low-level waste from the CERCLA environmental restoration activities within the INL Site.

The Radioactive Waste Management Complex (RWMC) historically managed, stored, and disposed of radioactive waste. Currently, RWMC manages solid transuranic and low-level radioactive waste. RWMC is removing and disposing of targeted waste from the Subsurface Disposal Area (SDA), remediating the SDA, disposing of transuranic waste at an off-Site facility, and demolishing facilities.

TAN, which is located at the north end of the Site, was built in the 1950s to house the nuclearpowered airplane project. CWI has completed cleanup operations at TAN, including demolishing 44 excess facilities. Groundwater is currently monitored at TAN to satisfy specific Comprehensive Environmental Response Compensation, and Liability Act (CERCLA)-related remedial action objectives.

\subsubsection{Advanced Mixed Waste Treatment Project Facility}

The Advanced Mixed Waste Treatment Project (AMWTP) retrieves mixed transuranic waste from temporary storage, characterizes the waste, treats the waste to meet disposal criteria, and packages the waste for shipment to the Waste Isolation Pilot Plant (WIPP) in Carlsbad, New Mexico. The AMWTP also receives other transuranic waste from INL Site contractors and off-Site DOE facilities for characterization, treatment, and shipment to WIPP. The AMWTP is operated by ITG. 


\subsubsection{Naval Reactors Facility}

The Naval Reactors Facility (NRF), operated by Bechtel Marine Propulsion Corporation, is specifically excluded from detailed discussion in this monitoring plan. As established in Executive Order $12344^{7}$, the Naval Nuclear Propulsion Program is exempt from the requirements of DOE Orders 458.1, Radiation Protection of the Public and the Environment ${ }^{1}$, and 414D, Quality Assurance ${ }^{8}$. The director, Naval Nuclear Propulsion Program, establishes reporting requirements and methods implemented within the program, including those necessary to comply with appropriate environmental laws. NRF's program is documented in the Naval Reactors Facility Environmental Monitoring Program ${ }^{9}$.

\subsubsection{Radiological and Environmental Sciences Laboratory (RESL)}

The Radiological and Environmental Sciences Laboratory (RESL) is a government-owned laboratory operated by the U.S. Department of Energy Idaho Operations Office. It is located in Idaho Falls within the REC. RESL and its predecessor organizations have been part of the DOE-ID since 1949. RESL provides an unbiased technical component to DOE oversight of contractor operations at DOE facilities and sites. As a reference laboratory, it conducts cost-effective measurement quality assurance programs that help assure that key DOE missions are completed in a safe and environmentally responsible manner. By assuring the quality and stability of key laboratory measurement systems throughout DOE, and by providing expert technical assistance to improve those systems and programs, it assures the reliability of data on which decisions are based. As a result, customers and stakeholders have greater confidence that those programs protect workers, the public, and the environment. RESL's core scientific capabilities are in analytical chemistry and radiation calibrations and measurements. 


\section{INL SITE ENVIRONMENTAL MONITORING OVERVIEW}

Effluent monitoring of airborne emissions and liquid effluents is driven by DOE and Environmental Protection Agency (EPA) requirements, state and federal regulations, and facility operating permits. Effluent monitoring refers to the collection and analysis of samples, or measurements of liquid and gaseous effluents for characterizing and quantifying contaminants, assessing radiation exposures of members of the public, controlling effluents at or near the point of discharge, and demonstrating compliance with applicable standards and permit requirements. Liquid and airborne effluents from facilities are monitored for radiological and nonradiological parameters.

Environmental surveillance is the collection and analysis of samples or direct measurements of air, water, soil, biota, and agricultural products from DOE sites and their environs. These activities are performed to generate measurement based estimates of the amounts or concentrations of contaminants in the environment. Measurements are performed by sampling ad laboratory analysis or by "in place" measurement of contaminants in environmental media. Environmental surveillance activities are discussed in more detail in Section 4 and are conducted to:

- Comply with DOE Order $458.1^{1}$

- Determine potential effects of contaminants on the public and the environment

- Evaluate pathways through which contaminants move in the environment.

In addition to effluent monitoring and environmental surveillance, meteorological conditions are monitored in and around the Site. Meteorological monitoring provides information needed to support and interpret the results of other monitoring and surveillance activities, particularly for air dispersion modeling. Meteorological monitoring activities are discussed in Section 5.

Ecological resource monitoring documents sensitive and threatened species on the Site, evaluates habitat needs, and monitors biota population trends and weed invasions in disturbed areas. These data better enable the evaluation of environmental impacts of operations and help determine restoration and mitigation needs. These activities are discussed in Section 4.9.

Cultural resource monitoring enables the Site Cultural Resources Management Office (CRMO) staff to gather baseline data and assess the condition of known cultural resources that have the potential to be impacted by natural processes, unauthorized activities, or inadvertently by project activities. If impacts are noted during monitoring visits, appropriate notifications are made as outlined in DOE/ID-10997, INL Cultural Resource Management Plan ${ }^{11}$ and as legitimized through Programmatic Agreement between the Idaho State Historic Preservation Office, the Advisory Council on Historic Preservation and DOE-ID. By identifying impacts to cultural resources in this manner and implementing mitigation or treatment plans, federal stewardship responsibilities are fulfilled by completing actions to avert further deterioration. Certain properties that are of special significance to the Shoshone-Bannock Tribes and other groups are monitored at least once per year while others are chosen based on known threats (i.e., close to public roads, ongoing projects in the vicinity). Because of tribal sensitivities, all projects that will disturb the ground in and around the CITRC area are monitored. Details of the annual monitoring activities are reported to DOE-ID annually in the INL Monitoring Report and are summarized for the public in the INL Cultural Resource Management Program Activities Report. A description of the INL Site CRMO monitoring program is located in Appendix L of DOE/ID $10997^{11}$.

A separate system of environmental monitoring and surveillance is activated during environmental events, which may be planned, as in startup of new equipment/process, or unplanned, such as operational events or wild fires. This environmental event monitoring is discussed in Section 6. Environmental reporting on compliance and regulatory sampling is discussed in Section 7. 
The locations of monitoring stations within and surrounding the Site are shown in Figure 2-1. Appendix A includes tables for various media monitored at the INL Site and contains each sample point and geographic location along with the organization responsible for the monitoring.

\subsection{History of Environmental Monitoring at the INL}

Some of the earliest environmental monitoring on the INL Site was completed by the U.S. Weather Bureau, which created a Research Station in 1948 to support the National Reactor Testing Station, as the INL Site was then called. The Research Station still exists as the Air Resources Laboratory Field Research Division (ARLFRD) of the National Oceanic and Atmospheric Administration (NOAA). The Station's task was to develop a basic understanding of the regional meteorology and climatology, with a focus on protecting the health and safety of workers and nearby residents using meteorological measurements and transport and dispersion models.

In 1949, the Health and Safety Division of the Idaho Operations Office of the Atomic Energy Commission collected numerous samples to determine the pre-reactor radionuclide background in soil, plants, animals, etc., at the Site ${ }^{13}$. The United States Geological Survey (USGS) also began monitoring hydrologic conditions of the Eastern Snake River Plain Aquifer (ESRPA) in 1949 by sampling nine onSite wells.

In 1959, the first of several aerial radiological surveys of the Site was performed under the direction of the Idaho Operations Office in an attempt to determine the extent of natural and man-made radioactivity. Subsequent aerial surveys performed in 1965, 1974, 1982, and 1990 focused mainly on characterizing facilities and associated regions of the $\mathrm{Site}^{14}$.

Between 1956 and 1963, ecological research was conducted on-Site by Health Services Laboratory (HSL), which focused on movement of radioactive contaminants through the food chain. Rabbits were sampled as indicators of the extent of contamination around Site facilities. In 1970, HSL established a routine soil sampling and monitoring program for radionuclides in the surface soils near INL Site facilities and the surrounding area.

In 1973, the Radiological and Environmental Sciences Laboratory (RESL) incorporated a biological component into its program that included extensive studies of radionuclide-contaminated areas and transport by biota from these areas. In 1977, HSL merged with RESL and the RESL Program continued on-Site and off-Site monitoring through 1993. 


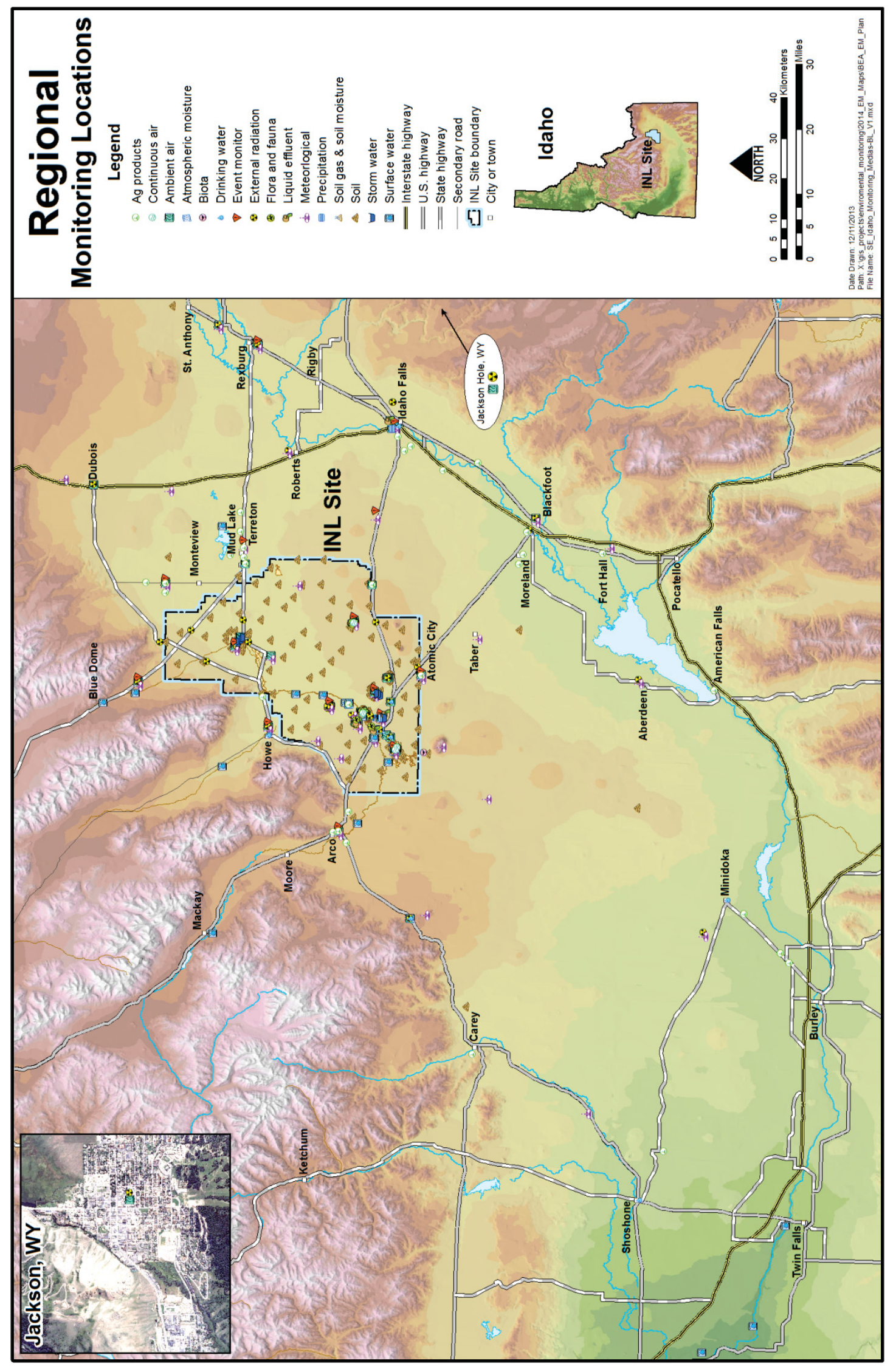


In 1989, the INL Site was placed on the National Priorities List found at http://www.epa.gov/superfund/sites/npl/. In 1991, DOE, EPA, and the state of Idaho signed the Federal Facility Agreement and Consent Order ${ }^{14}$ under 42 USC $§ 9601$, Comprehensive Environmental Response, Compensation, and Liability Act (CERCLA) ${ }^{15}$ to ensure that environmental hazards associated with contaminant releases were identified and remediation was completed. Since 1991, comprehensive remedial investigations/feasibility studies and Records of Decision (RODs) have been completed for most of the ten Waste Area Groups (WAGs) identified, and remediation in some areas has been completed. As part of CERCLA regulatory commitments, long-term monitoring is ongoing.

Also, in 1989, the Idaho Legislature established a comprehensive state oversight program for the INL Site. In 1990, Idaho became the first state in the nation to negotiate an agreement (Environmental Oversight and Monitoring Agreement ${ }^{16}$ ) with DOE to provide funding for independent environmental oversight and monitoring of a DOE facility. Over the years, the INL Oversight Program has developed an effective monitoring network to verify and supplement INL Site monitoring programs and to assure that DOE activities protect Idaho's environment. The INL Oversight Program also provides independent information concerning DOE impacts on the public and environment.

In 1994, DOE transferred the responsibility for on-Site environmental surveillance from RESL to the prime INL M\&O contractor, and all off-Site environmental surveillance was transferred to a private contractor under the Environmental Surveillance, Education and Research (ESER) Program. Currently, the ESER Program continues to conduct off-Site surveillance. The on-Site program was split in 2005 with award of contracts to BEA and CWI, whose facilities and activities are discussed in other parts of this plan.

Environmental monitoring performed by the various contractors in charge of facility operations initially involved limited sampling of liquid and airborne effluents from the facilities to develop waste inventory information and to meet operational monitoring objectives. Over the years, these contractor-run monitoring programs have evolved to ensure compliance with applicable federal, state, and local regulations and protect human health and the environment.

\subsection{Environmental Monitoring Organizations}

A number of organizations conduct environmental monitoring activities on or in the vicinity of the Site. Three organizations conduct monitoring at facilities they operate-BEA, CWI, and ITG. Other organizations perform INL Site-related environmental monitoring but do not operate facilities-NOAA, Gonzales-Stoller Surveillance, LLC (GSS), and USGS. Currently, BEA has Site-wide environmental monitoring responsibilities and conducts environmental monitoring at the facilities under its control.

Table 2-1 lists the environmental monitoring organizations at the INL Site and summarizes the environmental media monitored by each.

\subsubsection{ICP and INL Contractors}

The INL and ICP contractors conduct environmental monitoring activities at facilities under their respective areas of purview, as discussed in section 1.3 of this Plan. Both the INL and ICP contractors perform liquid and airborne effluent monitoring, along with environmental surveillance of ambient air, groundwater, drinking water, surface water runoff, soils, and external radiation. The ICP contractor also monitors biota. Compliance monitoring programs have been instituted to meet the monitoring requirements of federal, state, and local regulations, permits, and DOE orders. Requirements exist to sample drinking water, liquid effluents, injection well basins for storm water runoff, and groundwater. Facilities with airborne emissions are responsible for monitoring airborne effluents in compliance with the standards set forth in Public Law 91-604, Clean Air Act Amendments of $1990^{17}$ and Idaho Administrative Procedures Act (IDAPA) 58.01.01, Rules for the Control of Air Pollution in Idaho ${ }^{18}$. Those facilities with Wastewater Reuse Permits (WRPs) are monitored as required by their associated 
permits in accordance with the Wastewater Rules (IDAPA 58.01.16) ${ }^{19}$, the Recycled Water Rules (IDAPA 58.01.17) ${ }^{20}$, and the Ground Water Quality Rule (IDAPA 58.01.11) ${ }^{21}$.

Both INL and ICP contractors perform CERCLA monitoring of groundwater and soil, and the ICP contractor conducts ecological monitoring. A majority of the CERCLA monitoring is performed by the ICP contractor, because the INL contractor is only responsible for the CERCLA work at MFC. Sites with residual contamination will need to be monitored, controlled, operated, and maintained by institutional controls to protect human health and the environment.

Post closure monitoring is conducted to evaluate the effectiveness of the final remedies and ensure that no additional contamination is occurring. However, even though CERCLA regulates most INL Site stewardship activities, INL expects some stewardship activities to be regulated under the Resource Conservation and Recovery Act (RCRA), including post closure groundwater monitoring. The monitoring of facilities operated by both INL and ICP contractors will continue at the remediation areas for the period negotiated in the RODs 5-year review reports, in RCRA closure plans, or in other laws or agreements that govern the remedies.

Table 2-1. Summary of INL Site environmental monitoring organization activities.

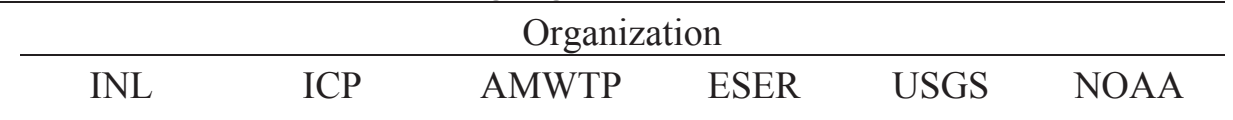

\begin{tabular}{|c|c|c|c|c|c|c|}
\hline \multicolumn{7}{|l|}{ Effluent } \\
\hline Airborne & $\mathrm{X}$ & $\mathrm{X}$ & $\mathrm{X}$ & & & \\
\hline Liquid & $\mathrm{X}$ & $\mathrm{X}$ & & & & \\
\hline Storm Water & $\mathrm{X}$ & & & & & \\
\hline \multicolumn{7}{|l|}{ Surveillance } \\
\hline Ambient Air & $X^{a}$ & $\mathrm{X}$ & & $\mathrm{X}^{\mathrm{a}}$ & & \\
\hline Drinking Water & $\mathrm{X}$ & $\mathrm{X}$ & & $\mathrm{X}$ & & \\
\hline Precipitation & & & & $\mathrm{X}$ & & \\
\hline Groundwater & $\mathrm{X}$ & $\mathrm{X}$ & & & $\mathrm{X}$ & \\
\hline Surface Water & & $\mathrm{X}$ & & $\mathrm{X}$ & $\mathrm{X}$ & \\
\hline Soil & $\mathrm{X}$ & $\mathrm{X}$ & & $\mathrm{X}$ & & \\
\hline Biota & & $\mathrm{X}$ & & $\mathrm{X}$ & & \\
\hline $\begin{array}{l}\text { Agricultural Products } \\
\text { \& Game Animals }\end{array}$ & & & & $\mathrm{X}$ & & \\
\hline External Radiation & $\mathrm{X}$ & $\mathrm{X}$ & & $\mathrm{X}$ & & \\
\hline Ecological & & $\mathrm{X}$ & & $\mathrm{X}$ & & \\
\hline Meteorological & & & & & & $\mathrm{X}$ \\
\hline
\end{tabular}


The staff of CRMO monitors cultural resources for both INL and ICP contractors. The CRMO provides cultural resource management services to the ICP contractor through an agreement between the two contractors. The CRMO services facilitate a coordinated and seamless management of Site cultural resources for DOE-ID and inform and educate stakeholders about the INL Site's more than 13,000-year history of rich and varied human land use. The CRMO staff of professional archaeologists, historians, and anthropologists conducts monitoring to determine if natural events or human activities are impacting Site cultural resources and to provide current information regarding the resources' preservation and protection. As required through an agreement between DOE-ID and the Shoshone-Bannock Tribes, the CRMO staff invites tribal participation during monitoring activities of properties that are of importance to them (Agreement-in-Principle 2007) ${ }^{22}$. Cultural resource management is described in detail in DOE/ID-10997, "Idaho National Laboratory Cultural Resource Management Plan"11.

\subsubsection{AMWTP}

The Idaho Treatment Group, LLC (ITG) performs limited environmental monitoring in compliance with the Clean Air Act.

\subsubsection{ESER Program}

The ESER Program, currently managed by GSS, primarily conducts off-Site environmental surveillance for DOE-ID. The ESER Program's primary responsibility is to monitor a number of different pathways by which radiological pollutants from the INL Site could reach the public. Current services provided by the ESER Program include off-Site sample collection and analyses of air (including analysis of moisture in air for tritium), precipitation, surface water, drinking water, soil, milk, wheat, lettuce, potatoes, alfalfa and animal tissue samples; measurement of external ambient radiation; wildlife habitat and vegetation surveys, and ecological research on and near the Site; research concerning endangered species, pollutants in the environment, and revegetation; environmental education concerning ecological and radiological issues around the INL Site; and preparing the Annual Site Environmental Report (ASER) summarizing environmental monitoring activities across the INL Site.

\subsubsection{USGS}

The USGS collects water samples and measurements in and around the Site boundary to describe hydrologic and geochemical conditions and to evaluate effects of waste disposal and other activities at the Site on the hydrogeologic system. The data are used to prepare interpretive reports. The USGS groundwater monitoring is detailed in DOE/ID-11034, "Idaho National Laboratory Groundwater Monitoring and Contingency Plan"43.

The USGS monitors more than 160 wells within a regional network in the ESRPA, both on-Site and off-Site, to study contaminant migration and determine groundwater quality and quantity as they relate to Site operations. Well placement within the regional network and constituent selection supplements existing INL and ICP contractors' groundwater monitoring programs. The USGS also monitors seven surface water sites on the Big Lost River, Little Lost River, Birch Creek, and Mud Lake.

\subsubsection{NOAA}

NOAA provides meteorological services and supporting research to the INL Site through the Air Resources Laboratory Field Research Division (ARLFRD). The ARLFRD operates a large meteorological monitoring network to characterize the meteorology and climatology of the eastern Snake River Plain, which includes the INL Site.

Meteorological monitoring data are required to characterize atmospheric transport and diffusion conditions in the vicinity of the Site and to represent other meteorological conditions (e.g., precipitation, temperature, and atmospheric moisture) that are important to environmental surveillance activities, such as air quality and radiological monitoring. 


\subsubsection{Idaho Environmental Monitoring Program}

The Idaho Environmental Monitoring Program (IEMP) is jointly supported by the INL Oversight Program, DOE-ID, NOAA, and the Shoshone-Bannock Tribes. Four weather stations were constructed in 1997 at publicly accessible locations in southeastern Idaho. These stations are located in Idaho Falls, Fort Hall, Terreton, and the Big Lost River Rest Area on U.S. Highway 20/26.

\subsection{Laboratory-wide Monitoring Committees}

\subsubsection{Monitoring and Surveillance Committee and Groups}

The INL Site has a Monitoring and Surveillance Committee (MSC) with participating organizations from DOE-ID, INL, ICP, AMWTP, NRF, ESER Program, INL Oversight Program, NOAA, USGS, and the Shoshone-Bannock Tribes. Chartered in 1997, the MSC provides a means for exchanging and sharing technical information, expertise and data. The MSC is to provide a collaborative atmosphere in which the participating organizations can communicate and discuss what they are doing in the areas of environmental monitoring and surveillance and make recommendations where appropriate.

\subsubsection{INL Water Committee}

The INL Water Committee was established in 1994 to coordinate drinking-water-related activities across the Site and to provide a forum for exchanging information related to drinking water systems. In 2007 the committee was expanded to include wastewater, storm water, and groundwater interests. In 2011, the Water Committee incorporated membership from the former Water Resource Committee to serve as a resource for the coordination and exchange of technical information on water-related activities.

The committee meets quarterly and includes participants from DOE-ID, USGS, INL, ICP, AMWTP, and NRF. Water and wastewater-related issues addressed during these meetings include regulatory issues, the Cross-Connection Program, construction activities, facility-specific activities, sampling, analytical results, and training. 


\section{EFFLUENT MONITORING}

Operations of Site facilities have the potential to release pollutants such as radioactive and nonradioactive contaminants into the environment. These pollutants can enter the atmosphere as airborne effluents and can enter surface and groundwater as liquid effluents or storm water runoff via injection wells. The following subsections summarize the effluent monitoring currently conducted by various organizations at the INL Site.

\subsection{Airborne Effluent}

Regulated facilities at the INL Site are required, under Public Law 91-604 ${ }^{17}$ and IDAPA 58.01.01 ${ }^{18}$, to measure and estimate airborne effluents. These facilities include:

- Advanced Mixed Waste Treatment Plant (AMWTP)

- Central Facilities Area (CFA)

- Idaho Nuclear Technology and Engineering Center (INTEC)

- Critical Infrastructure Test Range Complex (CITRC)

- Materials and Fuels Complex (MFC)

- Radioactive Waste Management Complex (RWMC)

- $\quad$ Test Area North (TAN)

- Advanced Test reactor (ATR) Complex

- Specific Manufacturing Capability (SMC)

- INL Research and Education Campus (REC)

One Tier I Operating Permit and several Permits to Construct have been granted by the Idaho Department of Environmental Quality (DEQ). These permits include specific air emission sources at the various Site facilities.

Numerous stack emissions are monitored for radioactive pollutants, but specific stack emission monitoring depends on the facility source term. Some monitoring is required by regulation or DOE order, and some monitoring is conducted as a best management practice or for facility information. Where monitoring is performed, emissions are normally sampled after abatement; otherwise, emissions are estimated on the basis of engineering calculations or process knowledge.

Continuous monitoring is required for emission points that have a potential to emit radionuclides ${ }^{\mathrm{a}}$ in quantities that could result in an effective dose equivalent (EDE) to a member of the public in excess of 0.1 millirem (mrem) per year, which is $1 \%$ of the of 10 mrem per year specified by the National Emission Standards for Hazardous Air Pollutants (NESHAP) 40 CFR 61, Subpart H5.

Monitoring for compliance and screening purposes is conducted in accordance with the guidance of 40 CFR 61, Appendix B, Method 114 ${ }^{23}$, ANSI N13.1, Sampling and Monitoring Releases of Airborne Radioactive Substances from Stacks and Ducts of Nuclear Facilities ${ }^{24}$, and the air monitoring recommendations of DOE/EH-0173T, Environmental Regulatory Guide for Radiological Effluent Monitoring and Environmental Surveillance ${ }^{4}$.

The contractor associated with each permitted facility at the Site is responsible for airborne effluent monitoring at their facility. Figure 3-1 shows the locations of those emission sources that currently require continuous monitoring by Subpart H of 40 CFR $61^{5}$. Sources shown in Figure 3-1 at RWMC

\footnotetext{
a The "potential to emit radionuclides" is evaluated by assuming normal facility operations; however no credit is taken for reduction of emissions by abatement equipment.
} 
include both RWMC and AMWTP as listed in Section 3.1. The following information on airborne effluent emissions and sources associated with contractor-operated facilities is summarized in DOE/ID10890, National Emission Standards for Hazardous Air Pollutants INL Report for Radionuclides ${ }^{25}$.

Other sources with the potential to emit low quantities of radioactive emissions also exist at other contractor-operated facilities. Emissions from sources that could cause annual doses to the maximally exposed individual greater than $10^{-5} \mathrm{mrem}$ are periodically monitored and included in calculating the INL Site's annual EDE to members of the public.

\subsubsection{INL Contractor}

The INL contractor-operated facilities are monitored for air emissions associated with R\&D and operational activities as described in the following paragraphs. Release points at INL Site facilities that do not require continuous monitoring are sampled periodically to provide emissions data for INL Site reports and permit requirements as well as a best management practice.

CFA. Minor releases occur from CFA facilities where work is routinely conducted with small quantities of radioactive materials. This includes operations at the CFA Laboratory Complex CFA- 625 . Only trace quantities of radioactive materials are used at the facility. Additional radioactive emissions are associated with decontamination activities, sample analyses, and site remediation.

ATR Complex. Radiological air emissions from the ATR Complex are primarily associated with operation of the Advanced Test Reactor. These emissions include noble gases, iodines, and other mixed fission and activation products. Other radiological air emissions are associated with hot cell operations, sample analysis, site remediation, and $R \& D$ activities.

REC. Radiological releases from the REC could arise from uncontrolled laboratory fume hoods within the INL Research Center (IRC) facility. Exhaust from most of the fume hoods is released directly to the outside atmosphere via the heat recovery fan system in the IRC heating, ventilating, and air conditioning system. Other potential release points include IF-603, the System Analysis Facility, RESL, and the INL Engineering Demonstration Facility.

MFC. MFC has three release points that require continuous emission monitoring as specified under 40 CFR 61, Subpart $\mathrm{H}^{5}$ : the Experimental Breeder Reactor (EBR)-II/Fuel Conditioning Facility Main Stack (MFC-764); the Hot Fuel Examination Facility Stack (MFC-785); the Fuel Manufacturing Facility (MFC-704); and the Irradiated Materials Characterization Laboratory (IMCL) (MFC-1729).

SMC. Operations at SMC include material development, fabrication, and assembly work to produce armor packages for the U.S. Department of the Army. Other activities include developing tools and fixtures and preparing and testing metallurgical specimens. Radiological air emissions from SMC are associated with processing of depleted uranium. Potential emissions are uranium isotopes and associated radioactive progeny. 


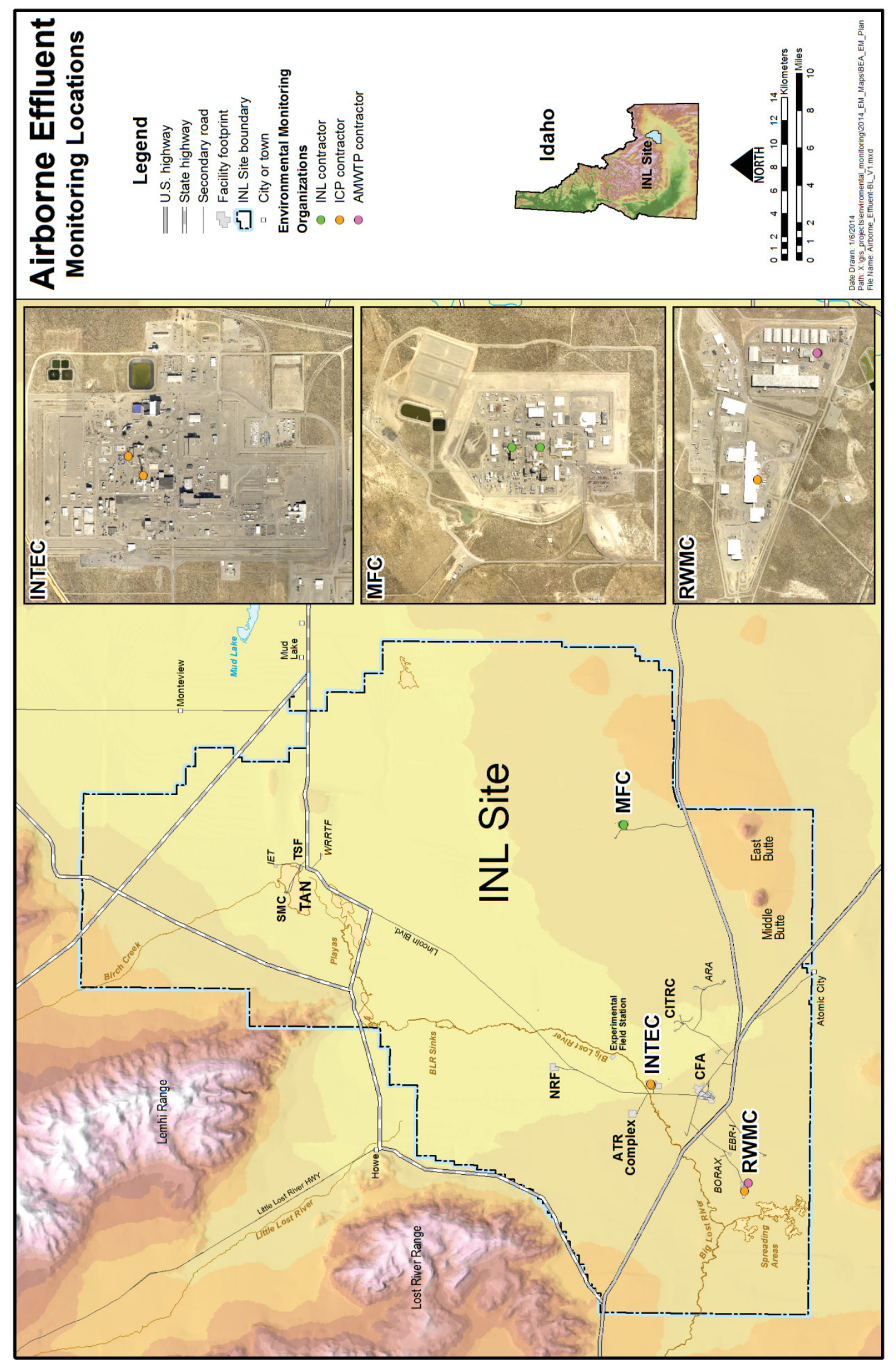




\subsubsection{ICP Contractor}

The ICP remediation and waste management activities are conducted in compliance with federal and state rules. The ICP radiological emissions originate from process equipment, deactivation/demolition activities, and waste management. The ICP monitors radioactive emissions at INTEC and RWMC as described in the following paragraphs:

INTEC. Emissions from INTEC are primarily associated with spent nuclear fuel management (e.g., fuel receipt and wet and dry storage areas). Radioactive emissions include noble gases, iodines, and other mixed fission and activation products. Additional radioactive emissions are associated with decontamination and debris treatment activities, site remediation, R\&D, radiological and hazardous waste accumulation areas, remote-handled transuranic waste characterization and repackaging, and other miscellaneous emissions from radioactively contaminated buildings and liquids in tanks. Emission monitors at the INTEC Main Exhaust Stack (CPP-708-001), Fluorinel Dissolution Process and Fuel Storage Stack (CPP-767-001), the New Waste Calcining Facility Stack (CPP-659-033), and the Integrated Waste Treatment Unit (IWTU) continuously monitor radiological emissions from these stacks.

RWMC. Radiological air emission point sources at the RWMC include three vapor vacuum extraction units in the Subsurface Disposal Area (SDA) and the Accelerated Retrieval Project (ARP) excavation enclosures. The ARP shows compliance with the NESHAP standard using ambient air measurements. Using the ambient air monitors for ARP compliance measurements is approved by EPA and meets the requirements specified by the NESHAP (40 CFR $61.93(\mathrm{~g}))^{26}$. Ambient air is monitored at the former ARP-V location (WMF-1617) for the RCRA Sludge Repackaging Project. EPA has approved continued use of the former ARP-V monitor to monitor for the Sludge Repackaging Project ${ }^{27}$. Three highvolume air samplers are located near the EBR-I facility, and a fourth sampler is operated at Howe, Idaho to serve as a control. The ARP ambient air measurement project is documented in ICP PLN-720, Environmental Surveillance Program Plan ${ }^{28}$. For emissions from the ARP, the EBR-I facility is a conservative surrogate location for the INL Site's maximally exposed individual.

Periodic/confirmatory measurements of carbon-14 (C-14) and tritium (H-3) emissions from the three vapor vacuum extraction units are made twice a year. As disposal areas are filled, they are covered with soil. Gaseous forms of radionuclides - particularly, H-3 and C-14 from activated beryllium - are released from the SDA surface soil. The amounts of these radionuclides released to air are estimated based on sitespecific corrosion data for buried beryllium, assuming that all of the $\mathrm{C}-14$ and $\mathrm{H}-3$ released to the soil by corrosion of the beryllium is immediately emitted to the atmosphere. Measurements of C-14 and H-3 in soil gas collected near a known beryllium disposal location are used to determine whether the release rate to soil has unexpectedly increased. A small amount of $\mathrm{H}-3$ is pumped from the aquifer beneath the RWMC for use at the facility, and then is released from the surface of the RWMC sewage lagoon. Emissions of $\mathrm{H}-3$ from the lagoon are conservatively estimated by assuming all of the H-3 pumped from the aquifer is immediately released to the atmosphere.

\subsubsection{AMWTP}

Operational features associated with the AMWTP consist of processes to vent waste containers, perform nondestructive examination of container contents, and certify, treat, store, and assemble and load waste containers for transport and disposal.

Operational activities at the AMWTP, operated within the Transuranic Storage Area at RWMC, could potentially result in the release of radiological and other pollutants to the atmosphere. Currently, AMWTP continuously monitors for radioactive particulates at three stack locations - two stacks on WMF-676 and one stack on WMF-636. Periodic confirmatory stack sampling is conducted for the characterization facilities WMF-634 and WMF-636. These emissions do not require continuous monitoring for NESHAP, but periodic confirmatory measurement is required to verify that emissions are less than 0.1 millirem per year. These emissions are monitored and calculated and are included in the Site's annual EDE to 
members of the public. Monitoring requirements for emissions are specified in AMWTP-MP-EC\&P-7.5, "Advanced Mixed Waste Treatment Project National Emissions Standards for Hazardous Air Pollutants Emissions of Radionuclides" $"$.

\subsection{Liquid Effluent}

Operations at the INL Site may result in the release of liquid effluent discharges containing radioactive or nonradioactive pollutants. Effluent monitoring includes the collection and analysis of samples and other measurements to establish the type and concentrations of pollutants in liquid discharges from facilities. Monitoring also provides data to evaluate the effectiveness of liquid effluent treatment and control systems, identifies potential contaminant source areas and environmental problems, and provides a mechanism for detecting, characterizing, and reporting unplanned releases.

Direct discharge of wastewater to the land surface is regulated under IDAPA 58.01.17, Recycled Water Rules $^{20}$, formerly the Wastewater Land Application Rules, and IDAPA 58.01.16, Wastewater Rules $^{19}$. Four facilities operated by the INL and ICP contractors have Wastewater Reuse Permits (WRPs) issued by the DEQ; all four require monitoring of liquid effluents for facility-specific parameters.

Additional liquid effluent monitoring is performed in support of DOE environmental protection objectives. Radiological liquid effluents are monitored in accordance with DOE Order $458.1^{1}$ and the recommendations of DOE/EH-0173T ${ }^{4}$. A risk-based approach, identified in PLN-8540, Idaho National Laboratory Liquid Effluent Monitoring Plan ${ }^{30}$, is used by the INL contractor to determine which nonpermitted effluent streams or additional nonpermitted parameters require monitoring. The ICP contractor has a similar approach documented in PLN-932, Management Plan and Implementation of Best Available Technology per DOE Order 5400.5 for Disposal of Wastewater ${ }^{31}$. The risk-based approach considers the likelihood that an effluent measurement equals or exceeds a regulatory limit or environmental release level. It will also determine the severity of the exceeded levels, were such an event to occur.

Figure 3-2 shows liquid effluent monitoring locations currently sampled across the Site. Some facilities have in-line alarm monitors located upstream from the routine effluent monitoring locations. These monitors are used to detect radiation or $\mathrm{pH}$ levels that fall outside predetermined levels.

\subsubsection{INL Contractor}

The INL contractor conducts sampling on the wastewater treatment systems at MFC, CFA, and the ATR Complex and monitors for nonradioactive and radioactive parameters in liquid waste effluents as required by the applicable WRP and DOE environmental protection objectives. Specific liquid effluent monitoring locations, frequencies, and analyses are documented in PLN- $8540^{30}$ and associated procedures.

Wastewater reuse permits (WRPs) are in effect for the ATR Complex Cold Waste Pond, the CFA Sewage Treatment Plant (STP), and the MFC Industrial Waste Pond and Industrial Waste Ditch. Discharge of wastewater to the land surface is regulated by wastewater rules (IDAPA $58.01 .16^{19}$ and $58.01 .17^{20}$ ). The CFA WRP requires monitoring but does not specify release limits. The WRPs for the ATR Complex Cold Waste Pond and the MFC Industrial Waste Ditch and Industrial Waste Pond specify maximum effluent concentrations for total suspended solids and total nitrogen. These facilities also have specific radiological and other parameters monitored for surveillance purposes in order to comply with DOE order458.1 $1^{1}$. Furthermore, the permits generally require that data from groundwater monitoring wells at the INL Site comply with the Idaho groundwater quality primary constituent standards and secondary constituent standards (IDAPA 58.01.11) ${ }^{21}$. The permits specify annual discharge volumes, application rates and effluent quality limits. All permitted and nonpermitted facilities are monitored in accordance with state of Idaho requirements. As a best management practice and to comply with DOE orders, the INL contractor also monitors the MFC sanitary sewage lagoon. 
The INL Site facilities located in Idaho Falls are required to comply with the applicable regulations in Chapter 1, Section 8 of the Municipal Code of the City of Idaho Falls ${ }^{32}$. Industrial wastewater acceptance forms are obtained for facilities that dispose liquid effluent through the City of Idaho Falls sewer system. Industrial wastewater acceptance forms include general requirements that apply to all REC facilities and specific monitoring requirements for the IRC owing to the nature of activities conducted therein. The city of Idaho Falls currently monitors effluents at the IRC for compliance with the City's wastewater acceptance criteria.

\subsubsection{ICP Contractor}

A WRP is in effect for the INTEC New Percolation Ponds. Discharge of wastewater to the land surface is regulated by IDAPA 58.01.16 ${ }^{19}$ and IDAPA 58.01.17 ${ }^{20}$. The INTEC WRP requires liquid effluent monitoring but does not specify any release limits. The facility also has specific radiological and other field parameters monitored for surveillance purposes in order to comply with DOE Order458.1 ${ }^{1}$. Furthermore, the permit generally requires that data from groundwater monitoring wells at the New Percolation Ponds comply with the IDAPA 58.01.11 ${ }^{21}$ groundwater quality primary constituent standards and secondary constituent standards. The permit also specifies daily and annual discharge volumes. Liquid effluent monitoring is performed in accordance with PLN-729, Idaho Cleanup Project Liquid Effluent Monitoring Program Plan ${ }^{33}$. 


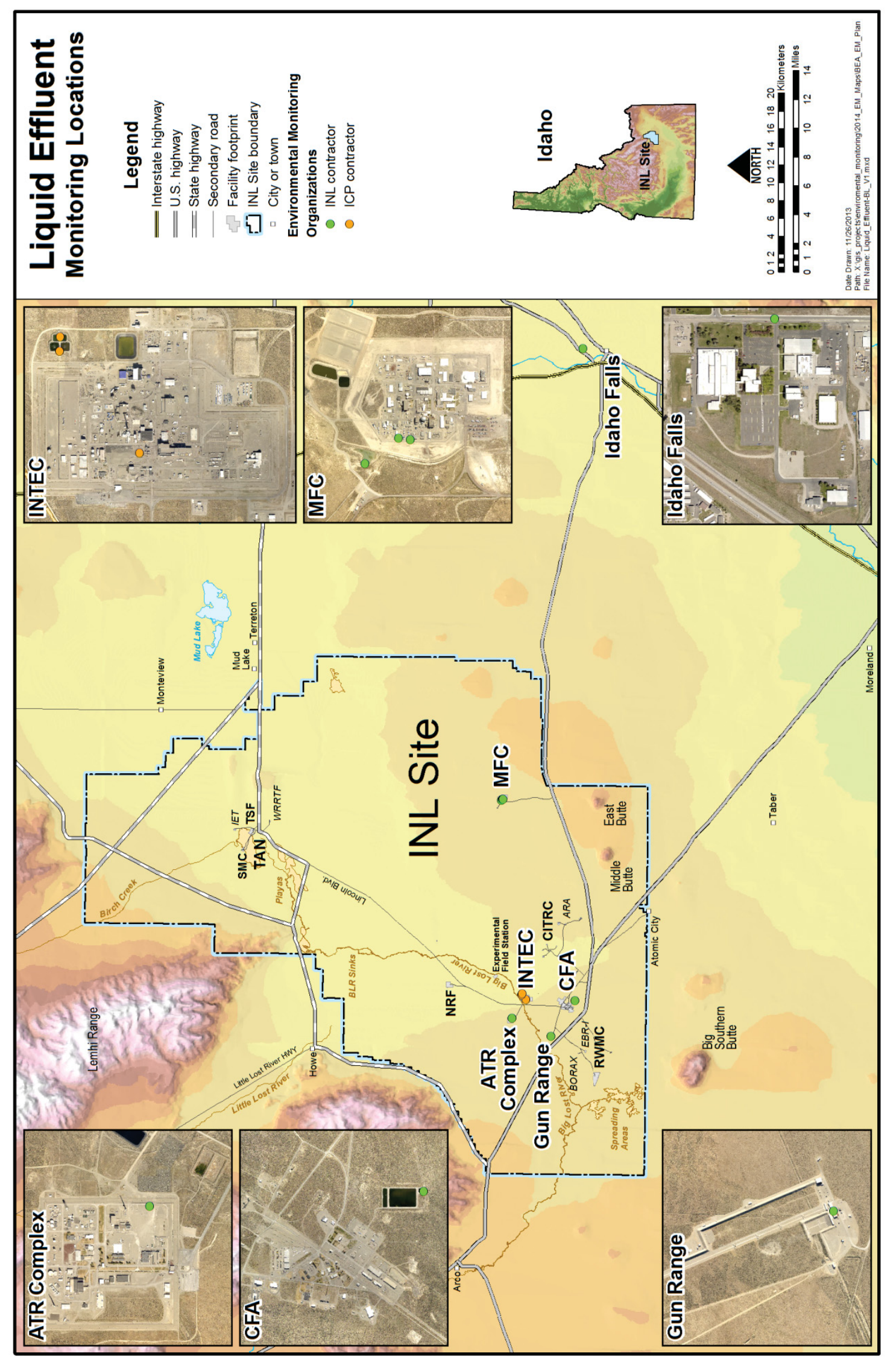




\subsection{Injection Wells}

Storm water discharges to injection wells are monitored to ensure compliance with state of Idaho permits and to protect the Snake River Plain aquifer (Figure 3-3) as regulated by IDAPA 37.03.03, Rules for the Construction and Use of Injection Well $^{34}$. Injection wells have been constructed to control flooding resulting from storm water or snowmelt runoff. The INL contractor monitors discharges of storm water at injection well locations during large precipitation events or snowmelt conditions to evaluate potential pollutants in the storm water. 


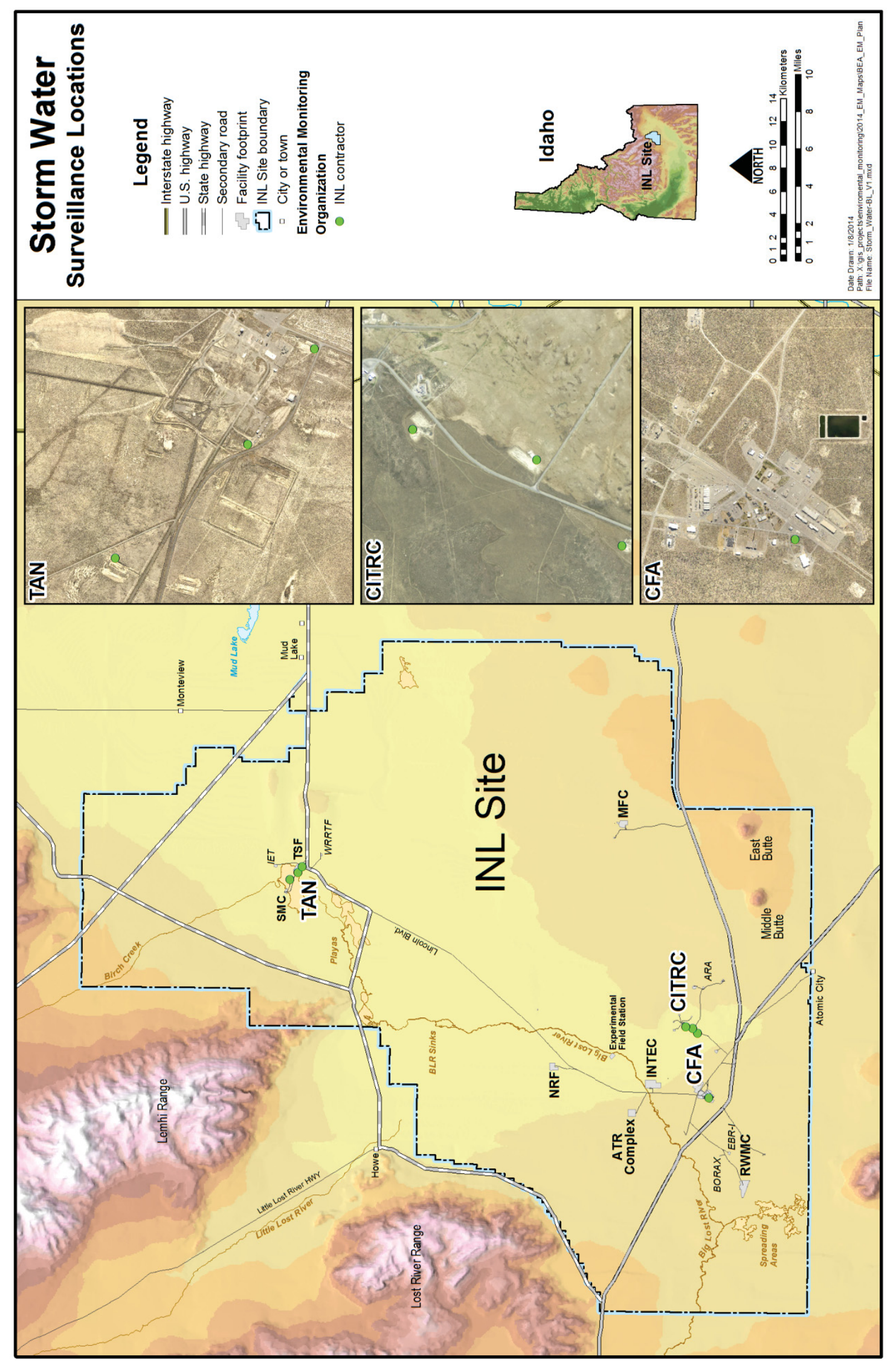

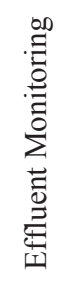

aे

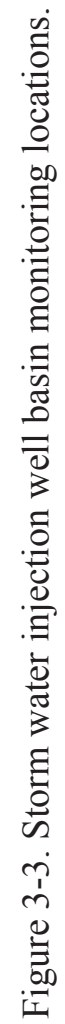




\section{ENVIRONMENTAL SURVEILLANCE}

Environmental surveillance at the INL Site includes the collection and analysis of samples or direct measurements of air, water, soil, biota, and agricultural products. Environmental surveillance is conducted by several organizations to support laboratory-wide compliance with DOE Order DOE Order 458.1 $1^{1}$, environmental laws and regulations and DOE agreements, and follows the criteria in DOE/EH- $0173 \mathrm{~T}^{4}$ for establishing environmental surveillance programs.

Separate on-Site environmental surveillance is required for waste management facility operations to meet DOE Order 435.1, Radioactive Waste Management ${ }^{3}$ requirements. The SDA at RWMC is the only low-level waste disposal facility at the Site and is required to be monitored for DOE Order $435.1^{3}$ compliance. Waste management surveillance monitoring is designed to be more facility- or sourcespecific than other site-wide surveillance.

\subsection{Ambient Air}

The air pathway is the most likely transport pathway for which INL Site contaminants could reach off-Site populations according to DOE/ID-12119, Idaho National Engineering Laboratory Historical Dose Evaluation $^{35}$. Using a network of low-volume air samplers, several organizations monitor ambient air to compare concentrations at on-Site release locations with off-Site control locations. The network of regional ambient air monitoring locations is shown in Figure 4-1, and the on-Site ambient air monitoring locations are shown in Figure 4-2. Ambient air particulate matter and airborne radionuclides are also sampled during wildfires or other emergency events. (Refer to Section 6.1 for a discussion of air monitoring performed for operational emergencies.)

The various organizations conducting air monitoring are discussed below.

\subsubsection{INL Contractor}

The INL contactor measures airborne radionuclides and monitors for potential trends in radioactivity in the environment per PLN-8510, Planning and Management of Environmental Support and Services Monitoring Activities ${ }^{36}$, PLN-8550, Environmental Support and Services Monitoring Services Surveillance Plan ${ }^{37}$, and supporting Laboratory Instructions (LIs). The ambient air monitoring activities support INL Site compliance with DOE Order $458.1^{1}$ and the Idaho Air Quality Operating Permit. Atmospheric particulates released from INL Site facilities, natural radioactivity, and global fallout from historical nuclear detonations or nuclear accidents are collected on- and off-Site using low-volume samplers and 2-in. filters. Potential gaseous iodine releases are monitored using activated charcoal cartridges. Atmospheric moistureis collected using digital flow meters and molecular sieves per LI-351, Sampling Atmospheric Tritium ${ }^{38}$ to monitor for tritium in water vapor (Figure 4-3)

\subsubsection{ICP Contractor}

The ICP contractor measures airborne radionuclides and monitors for potential trends in radioactivity in the environment per ICP PLN-720, "Environmental Surveillance Program Plan" 28 . The ICP ambient air monitoring activities support the waste management facility requirements of DOE Order $435.1^{3}$. A series of samplers that monitor for radioactive particulates is used around the RWMC SDA and at the Idaho CERCLA Disposal Facility (ICDF). Airborne materials from the SDA and ICDF are predominantly fugitive dusts potentially contaminated with small amounts of sorbed radionuclides. The samplers are located along the periphery of the SDA in predominant wind paths from disposal activities and at a control location north of Howe, Idaho.

\subsubsection{ESER Program}

The ESER Program conducts ambient air monitoring both on-Site and off-Site using a variety of monitors to determine if there is a gradient in radionuclide concentrations between the INL Site and offSite locations. These monitors include: 
- A network of low-volume air samplers on and around the INL Site to collect particulate matter on filters, and gaseous radioiodine on cartridges. Placement of these samplers is based on DOE regulatory guidance to monitor population centers within 50 miles, atmospheric transport and diffusion patterns modeled by NOAA ARLFRD, and on public interest. Filters are analyzed weekly for gross alpha/beta emitting activity and composited quarterly for analysis for gamma-emitting and specific alpha-emitting and beta-emitting radionuclides.

- A high-volume air sampler in Idaho Falls is operated as part of the EPA's RadNet Program, which monitors environmental radioactivity across the U.S. to provide high-quality data for assessing public exposure and environmental impacts resulting from nuclear emergencies and baseline data during routine operations. The sampler collects real-time data on gross beta and gamma activity, which EPA monitors from their RadNet headquarters. Filters are also collected biweekly from the Idaho Falls sampler by the ESER Program and are shipped to an EPA laboratory where they are analyzed for gross radioactive activity and concentrations of specific radionuclides. Results can be found at http://www.epa.gov/enviro/html/erams.

- Four atmospheric moisture monitors located in Atomic City, Blackfoot, Idaho Falls, and Sugar City, which collect water vapor samples for tritium analysis (Figure 4-3).

The ESER Program also collects precipitation samples to measure tritium in air. One sampler is located in Idaho Falls as a control or background sampler, and two others are located at the INL Site, one at CFA and the other at the Experimental Field Station near INTEC (Figure 4-4). The Idaho Falls station is operated as part of the EPA's RadNet Program. Ambient air monitoring locations, frequencies, methodologies, and analytes are specified in the ESER Environmental Program procedures ${ }^{39}$.

\subsection{Drinking Water}

Groundwater supplies the drinking water systems at the INL Site, and drinking water is monitored according to regulations to ensure that the drinking water at the facilities is safe for consumption in accordance with IDAPA 58.01.08, "Idaho Rules for Public Drinking Water Systems" 104-182, Safe Drinking Water Act ${ }^{41}$. All on-Site contractors participate in the INL Drinking Water Program as a means of sharing information, but each contractor administers its own drinking water monitoring program. Because of known contaminants, certain parameters are monitored more frequently than required.

Monitoring is based on the classification and size of the water systems (i.e. transient or nontransient noncommunity). Off-Site drinking water systems are also monitored by the ESER program due to the potential for contaminant migration beyond the Site boundary and are collected from taps. Samples collected off-Site are included as drinking water samples, but are not used for compliance with drinking water regulations. Instead, they are used to assess groundwater quality. Section 4.3 discusses the groundwater monitoring samples taken directly from wellheads.

Transient, noncommunity water systems on the Site are the CITRC, EBR-I, Gun Range, Test Area North/Technical Support Facility and the main gate. Nontransient, noncommunity water systems have more stringent compliance requirements than transient, noncommunity water systems. The nontransient, noncommunity water systems at the Site are INTEC, RWMC, CFA, ATR Complex, Test Area North/Contained Test Facility, and MFC. 


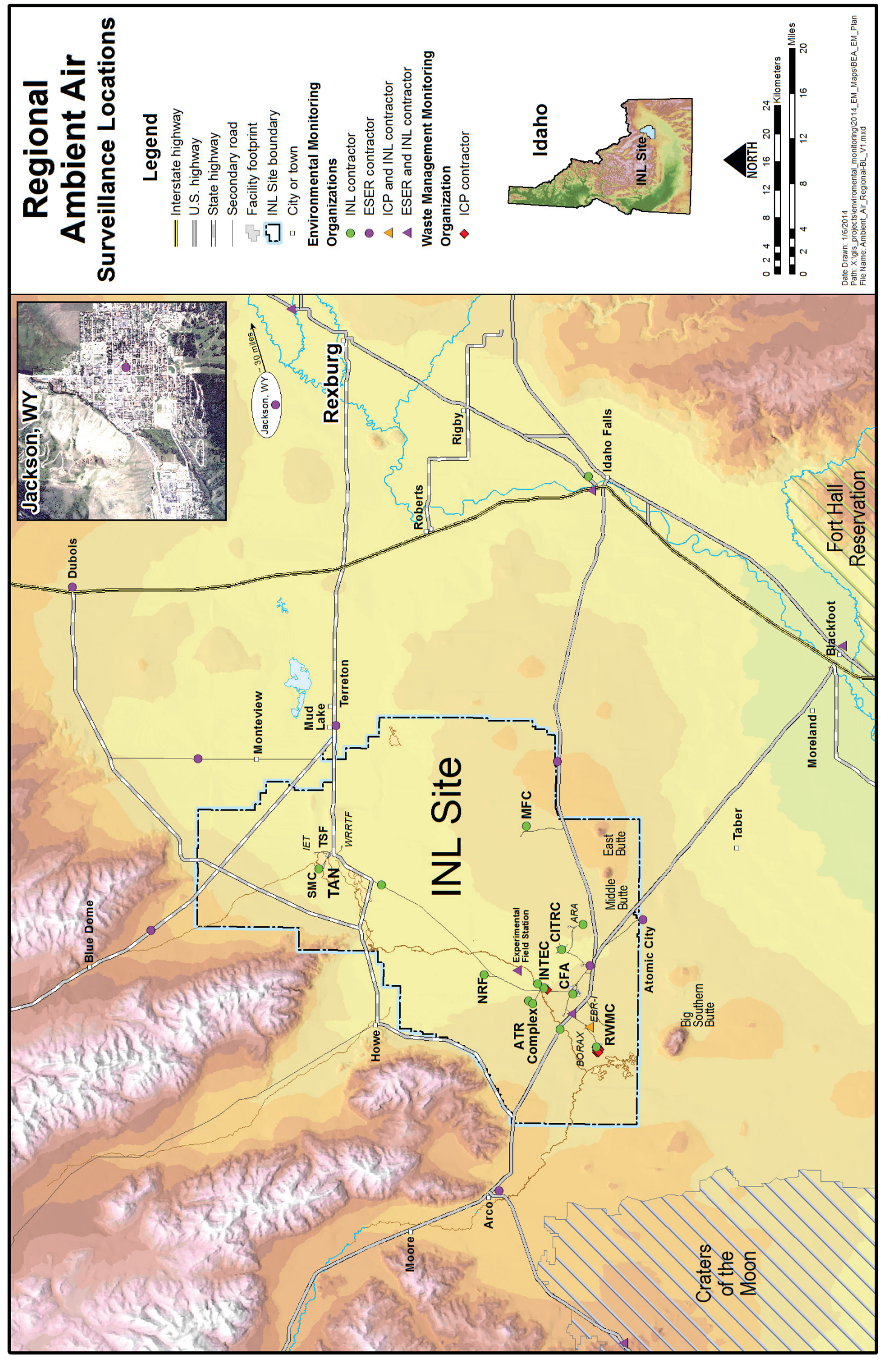

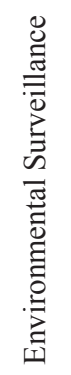




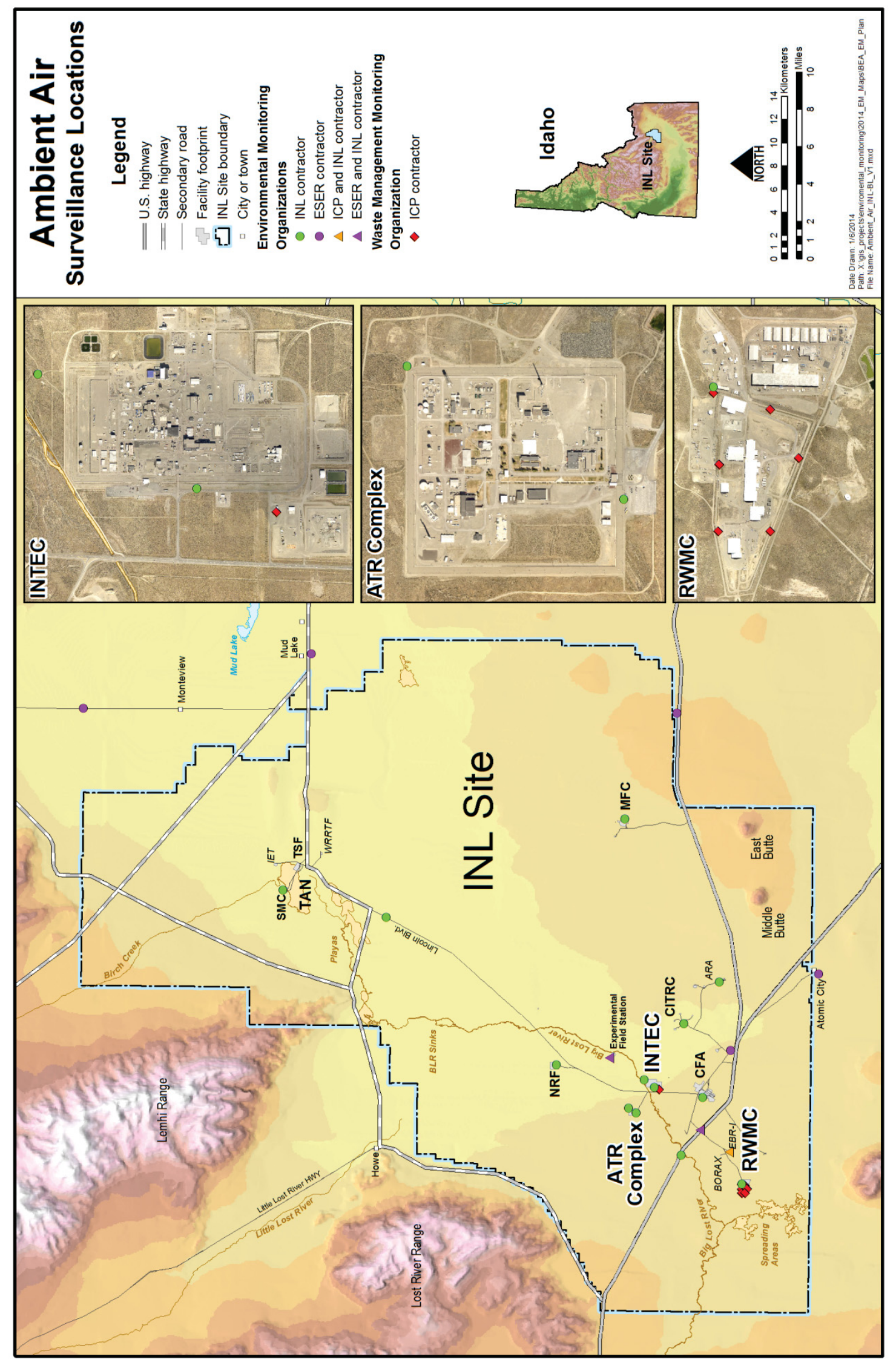

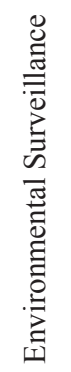




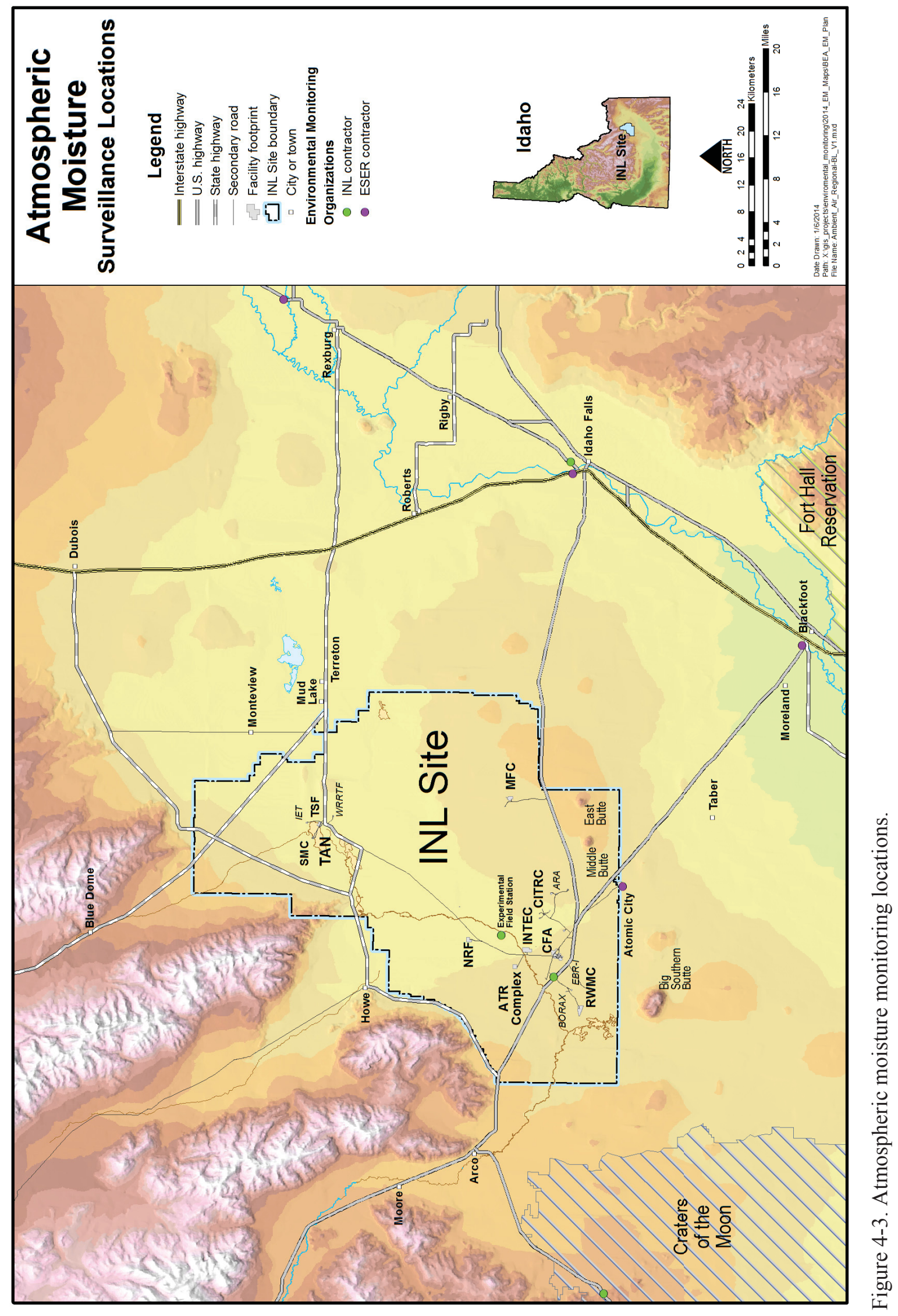




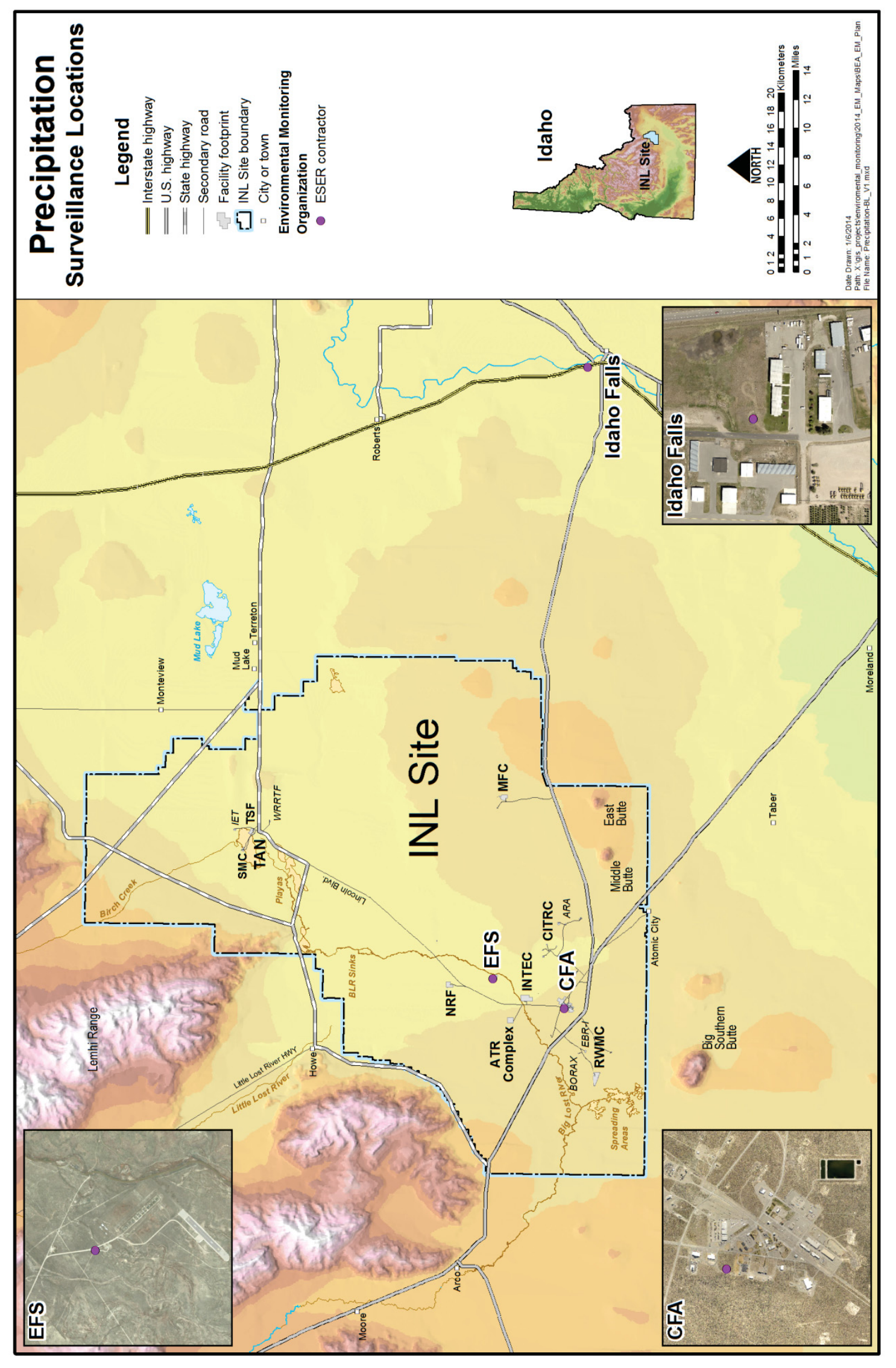

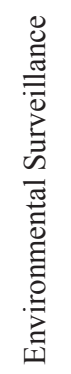

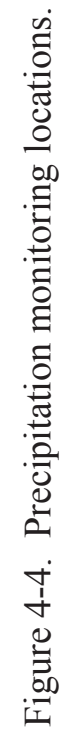


Figure 4-5 shows regional drinking water monitoring locations. On-Site drinking water samples are collected from the point of entry to each distribution system or manifold, directly from the wellheads, and from buildings associated with each drinking water distribution system. Figure 4-6 shows the detailed locations of those manifolds and wellheads that are currently monitored across the INL Site. Individual sampling points from each drinking water distribution system are not shown on Figure 4-6 because these sample points include most buildings connected to the distribution system.

\subsubsection{INL Contractor}

The INL contractor performs all drinking water monitoring and is responsible for all site drinking water systems with the exception of INTEC and RWMC, which are ICP contractor facilities. Currently, the INL contractor monitors 17 wells and nine distribution systems across the Site for both radiological and nonradiological parameters. Sampling locations, parameters, and frequencies are documented in the PLN-8530, Idaho National Laboratory Drinking Water Program Plan ${ }^{42}$, and associated procedures.

\subsubsection{ICP Contractor}

The ICP contractor monitors drinking water systems at INTEC and RWMC. The ICP contractor is responsible for regulatory compliance at these facilities. Sampling locations, parameters, and frequencies are documented in PLN-730, "Idaho Cleanup Project Drinking Water Program Plan" procedures.

\subsubsection{ESER Contractor}

The ESER contractor collects drinking water at Atomic City, Craters of the Moon, Howe, Idaho Falls, Minidoka, Mud Lake, Shoshone, and the public rest stop on Highway 20/26. The last location is the only public drinking water site located close to the mapped tritium plume from the INL Site. Howe is monitored because it is close to the INL Site boundary and the Big Lost River Sinks.

The water at Atomic City, Minidoka, Mud Lake and Shoshone are is co-located with the state of Idaho Department of Environmental Quality INL Oversight Program. A subsample of the Idaho Falls sample is sent to EPA for analysis as part of the EPA RadNet program. These samples are all distant from the INL Site groundwater plume but are of interest to the public.

The Craters of the Moon and Idaho Falls locations are outside the influence of the groundwater plume and are used for background comparison with the other sites.

All samples are analyzed for gross alpha/beta activity and tritium. 


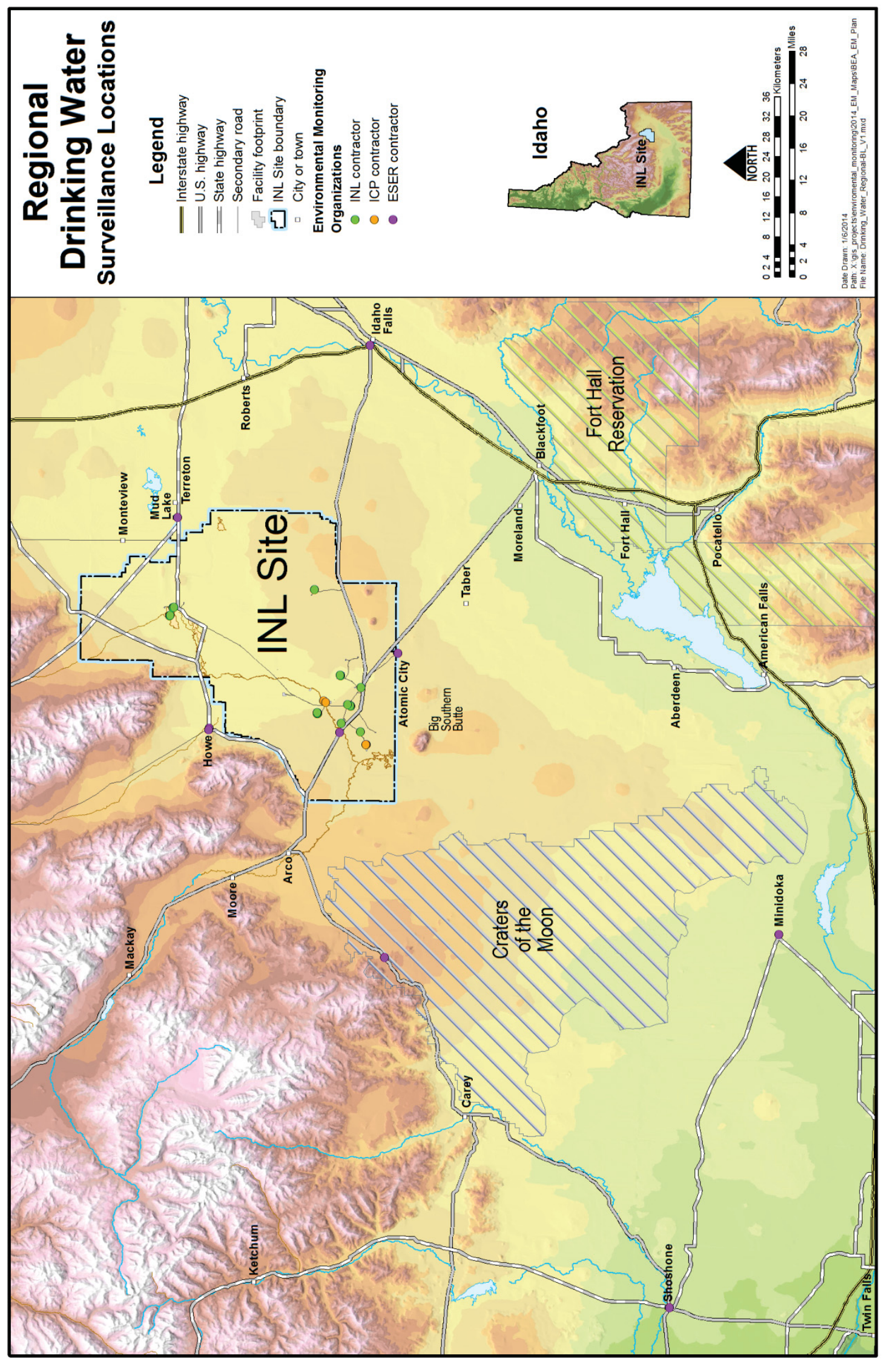

$\underset{j}{j}$ 


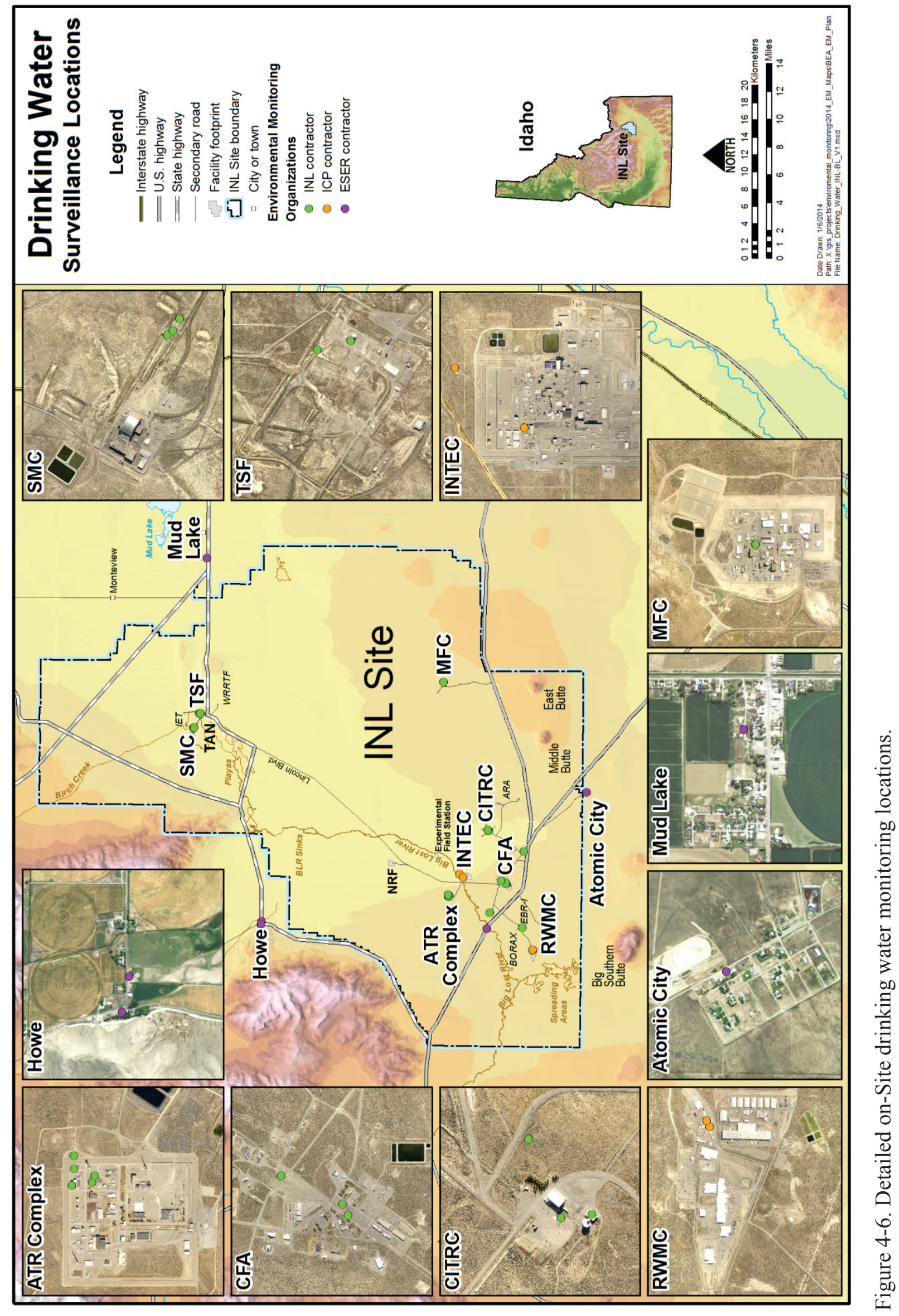




\subsection{Groundwater}

Historic waste disposal practices have produced localized areas of contamination in the ESRPA beneath the INL Site. The ESRPA is the source of regional drinking water and supplies irrigation water to a large, regional agricultural and aquaculture economy. On-Site groundwater samples are taken from wells near each facility, in areas of known contamination, and regionally across the Site (including upgradient of Site operations). Contaminants resulting from past INL Site operations have been detected in the ESRPA beyond the Site's southern boundary at concentrations far below regulatory limits. Off-Site groundwater samples are taken downgradient of the INL Site near the INL Site boundary and near the terminus of the ESRPA.

Groundwater is currently monitored at the INL Site by multiple organizations to:

- Satisfy specific CERCLA-related remedial action objectives and/or regulatory requirements contained in RODs, RCRA regulations, WRPs, and DOE orders

- Determine the nature and extent of groundwater contamination during CERCLA remedial investigation/feasibility study activities

- Evaluate general groundwater conditions and contaminant fate and transport on a regional and subregional scale (as performed by the USGS and WAG 10).

The groundwater monitoring programs established by the contractors responsible for managing and operating INL Site facilities, at a minimum, address regulatory compliance and remediation goals at each of the facilities for which they have management responsibility. DOE/ID-11034, Idaho National Laboratory Groundwater Monitoring and Contingency Plan $^{44}$, provides an overview of the routine groundwater monitoring conducted on-Site and specifies how the recommended elements of a groundwater monitoring program under DOE Order 458. $1^{1}$ are met. All approved CERCLA documents and associated groundwater monitoring activities can be found in the Administrative Record/Information Repository at ar.inel.gov.

\subsubsection{INL Contractor}

The INL contractor is responsible for groundwater monitoring at MFC per the CERCLA ROD and the WRP for the Industrial Waste Ditch and Pond, and at the ATR Complex in compliance with the WRP for the Cold Waste Pond.

\subsubsection{ICP Contractor}

Except for MFC and NRF, the ICP contractor is responsible for groundwater monitoring conducted at all other CERCLA site monitoring locations, WRP compliance at INTEC, and RCRA post-closure monitoring at INTEC's Waste Calcining Facility and CPP-601/627/640 Landfill. The ICP contractor currently performs data interpretations to determine the cumulative impact of CERCLA sites at the INL Site.

\subsubsection{USGS}

USGS monitors ESRPA wells within its defined regional network (both on-Site and at boundary locations) to study contaminant migration and determine groundwater quality and quantity as they relate to Site operations. The Site boundaries are monitored to detect groundwater contaminants entering and leaving the INL Site. Wells within the Site boundary are monitored to evaluate contaminant movement in the ESRPA between facilities.

Each monitoring well in the USGS regional network is monitored for the contaminants of concern specific to its locale and known or suspected contaminant sources. In general, on-Site ESRPA wells outside of facility fences are sampled by the USGS annually, depending on location. Samples are routinely collected and analyzed for radionuclides, volatile organic compounds, trace elements, and 
anions. Sampling locations, methodologies, and parameters are specified in DOE/ID-22206, Field Methods and Quality Assurance Plan for Quality-of-Water Activities, US Geological Survey, Idaho National Laboratory, Idaho ${ }^{45}$.

\subsection{Surface Water}

The Big Lost River system includes the Little Lost River, Big Lost River, Birch Creek, and associated tributary channels, playas, and sinks. No streams or rivers flow from within the Site to locations outside the boundaries, and most years, the channels of the Big Lost River system on the INL Site are dry. However, surface water samples are taken when water is present both on and around the Site to monitor the surface water pathway. Currently, there are no discharges of storm water or liquid effluent from INL Site facilities that require monitoring under 33 USC $\S 1251$, Federal Clean Water Act ${ }^{46}$. Figure 4-7 shows all of the current on-Site and off-Site surface water monitoring locations.

\subsubsection{ICP Contractor}

Surface and near-surface soils at RWMC have become contaminated from waste handling and biotic intrusion during past flooding of open pits. Surface water runoff is sampled at the SDA because of the potential for surface water runoff to become contaminated. Sampling locations, parameters, and frequencies are documented in the ICP PLN-720 28 and associated procedures. These samples are collected to comply with the following objectives:

- Meet the requirements for waste management facility monitoring per DOE Order $435.1^{3}$.

- Determine concentrations of radionuclides in surface water leaving the facility.

- Report comparisons of measured concentrations against derived concentration guides for the public. Derived concentration technical standards are calculated from DOE dose equivalent tables and based on DOE radiation protection standards given in DOE Order 458.1 ${ }^{1}$.

- Detect and report significant trends in measured concentrations of radionuclides in surface waters leaving the SDA with the potential of leaving the facility.

\subsubsection{ESER Contractor}

Surface water is sampled on the Big Lost River (BLR) through the INL Site, as it has the potential to carry contaminated soil to the BLR Sinks. The samples are analyzed for gross alpha/beta activity and tritium. In addition, gamma spectroscopy is performed on these samples, as cesium (Cs)-137 is a major soil contaminant at the INL Site.

Samples are collected semiannually at five locations along the BLR, from the Highway 20/26 to the BLR Sinks, when water is available.

Surface water is also collected semiannually at locations downgradient of the BLR Sinks at Buhl, Hagerman, and Twin Falls. These locations are co-sampled with the state of Idaho Department of Environmental Quality INL Oversight Program and are analyzed for gross alpha/beta activity and tritium. 


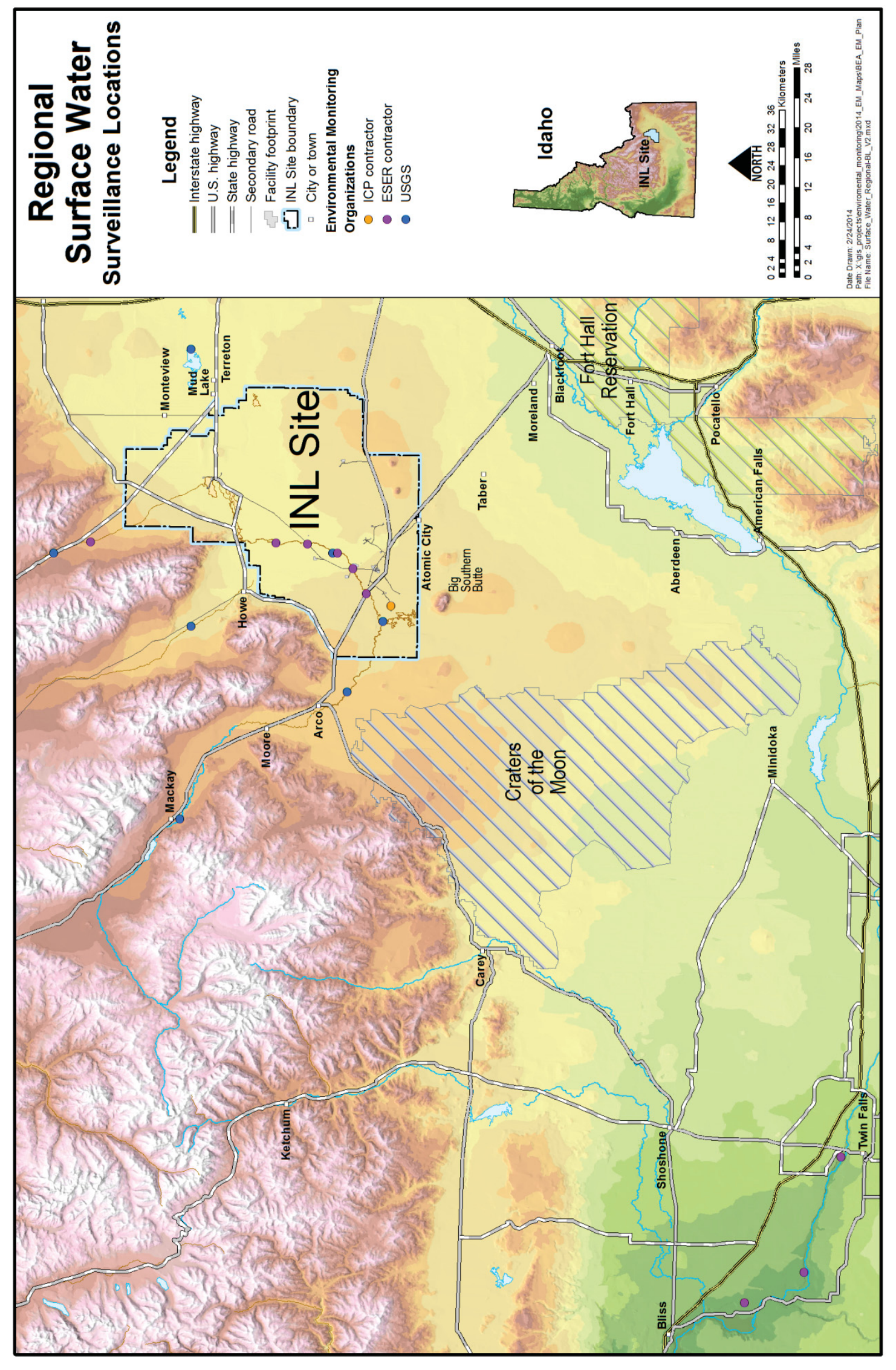

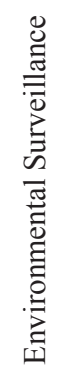

: 


\subsubsection{USGS}

When flow occurs in the Big Lost River or other selected streams, surface water samples are collected annually and submitted for radionuclide and chemical analyses to determine the effect that surface water flow has on the chemistry of groundwater beneath the Site.

The USGS takes surface water samples from Birch Creek, the Little Lost River, and Mud Lake, and from four locations on the Big Lost River. The Big Lost River on-Site sampling locations include the INL Diversion Dam near RWMC and the Experimental Field Station near INTEC. The off-Site sampling locations are located near Mackay and Arco. Details on the surface water sampling performed by the USGS are specified in DOE-ID-22206 ${ }^{45}$.

\subsection{Soil}

Some INL Site soils have been contaminated by radioactive and nonradioactive effluents from INL Site operations and from nuclear weapons testing fallout. Soil sampling is conducted at the Site to:

- Determine present concentrations of nonradioactive contaminants and radioactivity (natural and anthropogenic) in soil

- Identify and quantify changes in contaminant concentrations in the soil caused by INL Site operations

- Comply with regulatory requirements

- Provide data used to calculate fugitive air emissions.

Figure 4-8 shows regional soil monitoring locations, and Figure 4-9 shows detailed on-Site soil monitoring locations.

\subsubsection{INL Contractor}

The INL contractor conducts soil sampling in compliance with DOE Order $458.1^{1}$ requirements for monitoring to determine the impacts of operations on the environment and public health, and for compliance with the WRP for the CFA STP irrigation area.

Soil monitoring activities are conducted primarily to determine if long-term deposition of airborne materials released from INL Site facilities have resulted in a build-up of radionuclides in the environment. Soils are analyzed on a yearly rotation schedule around all INL Site facilities and regionally using portable in situ gamma spectrometers capable of detecting gamma-emitting radionuclides. A subset of these locations shown in Figures 4-8 and 4-9 are monitored on an annual basis to provide a radiological baseline for gamma-emitting radionuclides in soils. Roadways and Site facility perimeters are monitored on an annual basis using vehicle-mounted radiation detectors. These systems provide backgroundcorrected count rate and isotopic concentration data, which is mapped for each measured roadway or facility perimeter. Geostatistical and trend analyses are performed on the radiological data to evaluate the soil radionuclide concentrations over time at the INL Site.

Soil samples taken in support of the CFA STP WRP are analyzed for nonradiological contaminants to determine the effect of wastewater irrigation on soil chemistry. These soil samples are collected in accordance with the permit and company-controlled procedures.

\subsubsection{ICP Contractor}

The ICP contractor conducts soil sampling in compliance with DOE Order $435.1^{3}$. Locations of soil samples taken at the RWMC are selected from specific areas at the SDA. Surface and near-surface soils at RWMC have become contaminated from past flooding of open pits, waste handling, and biotic intrusion. Soil sampling is performed because wind, water, and biota can transport contaminated soil particulates on-Site and off-Site. The areas at the SDA delineated for sampling include active areas, Pad A, inactive 
areas, and previously flooded areas. Soil samples are collected at the SDA every three years. Details of this sampling can be found in ICP PLN-72028.

Soil sampling is performed as required by the remedial investigation/feasibility study (RI/FS) activities, RODs, and as part of the CERCLA Long-Term Ecological Monitoring Program to verify that the remedial objectives of each CERCLA ROD are maintained and that the long-term INL Site-wide ecological impact of the contamination left in place remains within acceptable limits.

Under the CERCLA Long-Term Ecological Monitoring Program, soil samples will be taken at locations identified as sites of concern and will be monitored for both radiological and nonradiological contaminants. Soil samples will be collected from the surface to no more than $0.61 \mathrm{~m}(2 \mathrm{ft})$ below ground surface and will consist of composites from locations within the sampling plots that correspond to plants from which vegetation samples are collected. This depth is anticipated to concentrate sampling and analytical efforts on the depth most likely to pose a source of contamination to plant roots and ingestion/physical exposures to surface dwellings and burrowing animals. These soil samples are collected in accordance with INEEL/EXT-02-01191, Long-term Ecological Monitoring Plan for the Idaho National Engineering and Environmental Laboratory ${ }^{47}$. Because the locations of this monitoring can be extensive and vary within each site of concern, the actual sampling locations are not depicted on the soil figures.

The ICP contractor performs additional monitoring to comply with EXT-95-00496, Record of Decision Declaration for Central Facilities Area Landfills I, II, and III (Operable Unit 4-12), and No Action Site, (Operable Unit 4-03) ${ }^{48}$, and to support ongoing work for a WAG 7 RI/FS of RWMC areas. At CFA, moisture content in the soil is monitored by neutron access tubes adjacent to the landfills; moisture infiltration through the soil cover of the landfills is monitored using time-domain reflectometry arrays; and soil gas is monitored through a series of soil-gas sampling ports at varying depths adjacent to the landfills in accordance with Idaho National Engineering Laboratory (INEL)-95/0585, Field Sampling Plan (FSP) for Post-Record of Decision (ROD) Monitoring for the Central Facilities Area (CFA) Landfills I, II, and III Under Operable Unit (OU) 4-1249.

At RWMC, soil moisture and soil gas are monitored to support the WAG 7 CERCLA activities. The data collected for WAG 7 are also used to satisfy the requirements of DOE Order $435.1^{3}$. Soil moisture monitoring in the vadose zone using lysimeters at RWMC is addressed in Section 4.3.2. Soil gas is sampled in the waste zone using vapor probes placed directly in the waste at selected locations. Soil gas is sampled in the vadose zone using an extensive system of soil gas sampling ports inside and outside the SDA boundary. Figure 4-10 shows the soil gas and soil moisture monitoring locations.

\subsubsection{ESER Contractor}

Soil samples are used to establish background levels of radionuclides (both natural and those resulting from fallout from nuclear weapons testing) and to detect any long-term buildup of radionuclides from the INL Site in off-Site soils. Soil is taken from 12 off-Site locations during even-numbered years for Sr-90 and transuranic and gamma-emitting radionuclide analyses. Co-sampling is conducted with the state of Idaho Department of Environmental Quality INL Oversight Program at St. Anthony, Mud Lake, Monteview, Butte City, Carey, and Crystal Ice Caves. Details on the soil sampling performed by the ESER Program are specified in the ESER Environmental Program soil sampling procedure ${ }^{39}$. 


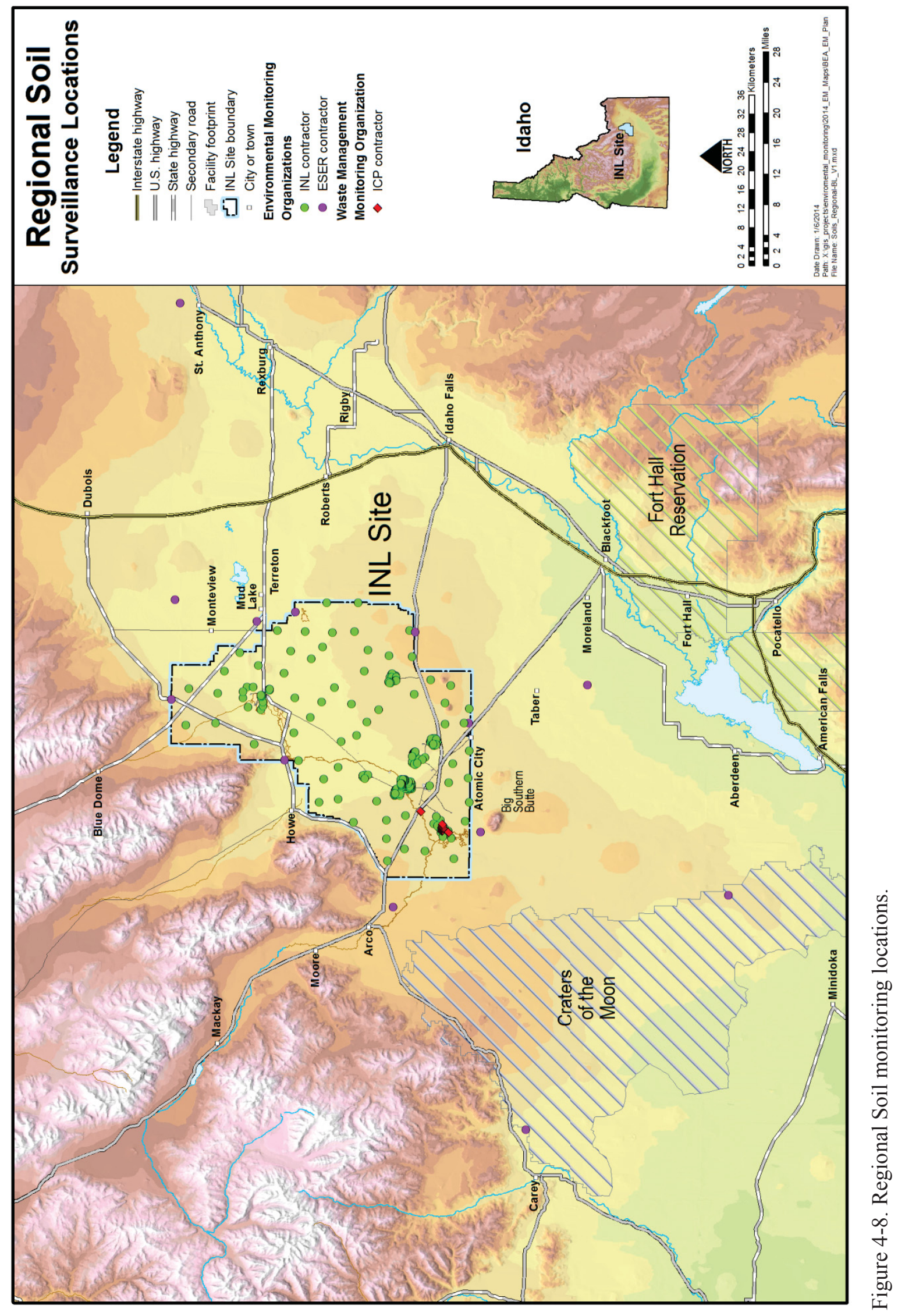




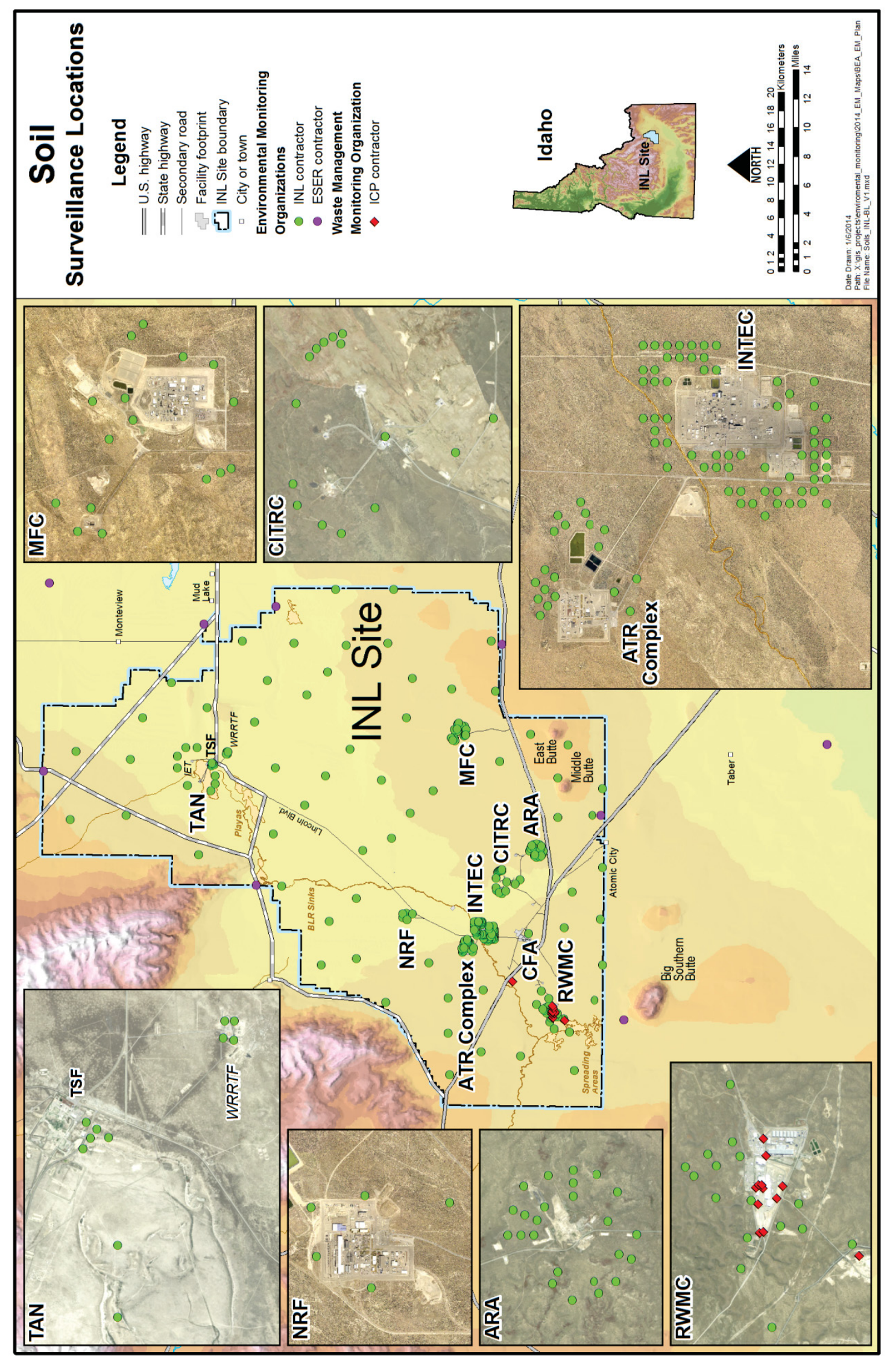

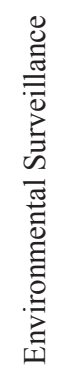

$\stackrel{\dot{0}}{\stackrel{0}{0}} \quad \frac{0}{\dot{t}}$ 


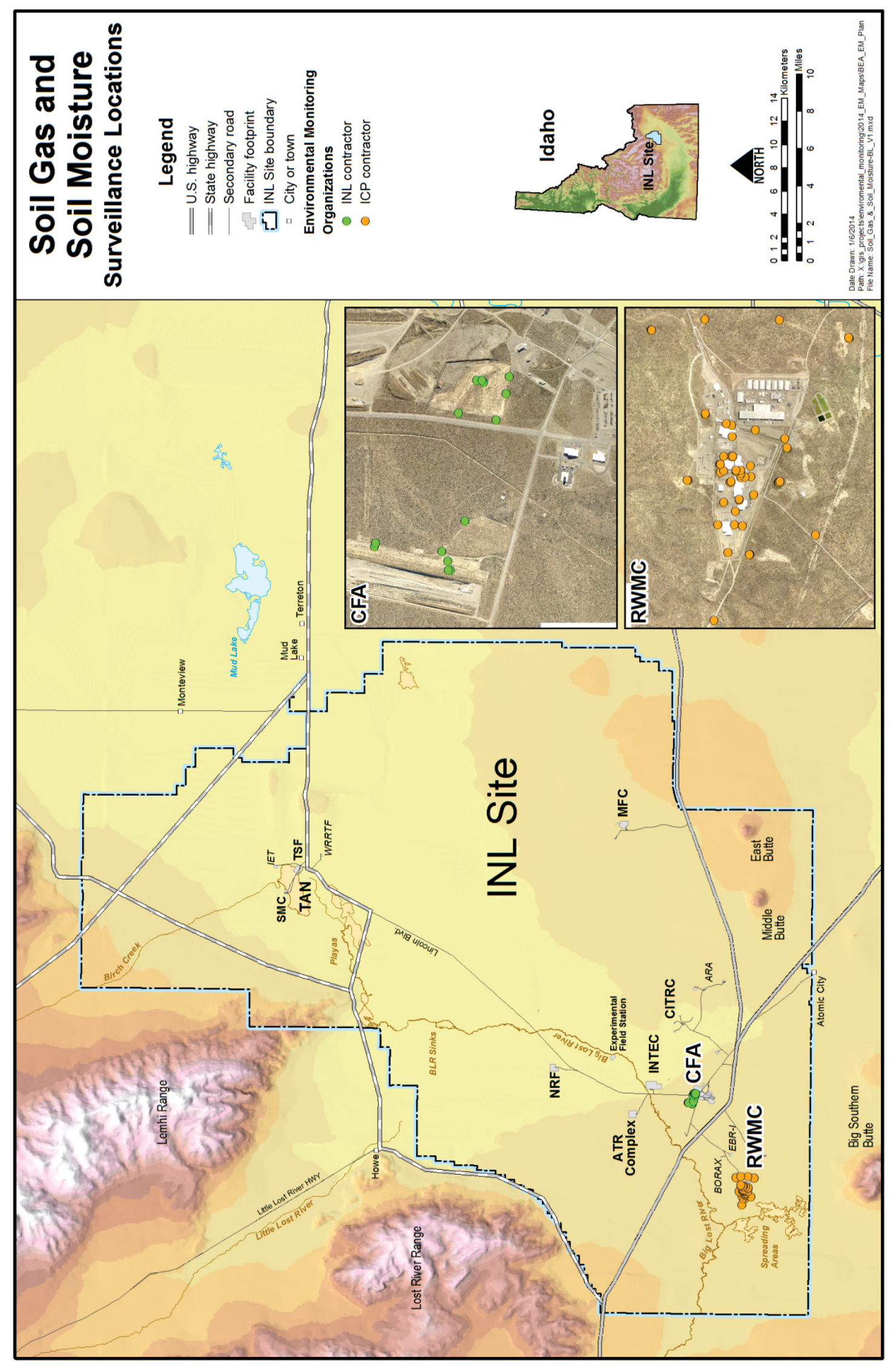

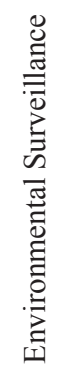

$\frac{1}{7}$ 


\subsection{Biota}

Plants represent the major linkage in transfer of soil-borne contaminants to primary consumers and higher trophic levels. The leaves, florets, and shoots of plants can accumulate constituent concentrations caused by wind-blown contamination and uptake from the soil. Belowground plant components can also accumulate certain contaminants, although most birds and mammals are expected to consume primarily aboveground components. Plants are sampled to determine potential migration of facility contaminants and to ensure waste confinement integrity.

Wildlife has access to some areas on the Site containing radioactive contamination. Because wildlife has the potential to move off-Site and be harvested by the public for consumption, wildlife is sampled to document levels of radioactivity in the edible tissues. Small mammal species are sampled to determine long-term ecological impacts of contamination and assess waste confinement integrity. Figure 4-11 shows the biota monitoring locations.

\subsubsection{ICP Contractor}

The ICP contractor performs both CERCLA and non-CERCLA biota sampling activities. Routine non-CERCLA monitoring is performed to:

- Determine if biota are transporting radionuclides from buried waste or contaminated soil

- Identify biotic conditions that may compromise waste confinement at waste storage and disposal facilities

- Detect and report significant trends in the radionuclides and concentrations in biotic samples.

Plants at the RWMC SDA are sampled to comply with DOE Order $435.1^{3}$ and to monitor waste confinement integrity because radionuclides may migrate away from the facility. Vegetation is collected from a control location approximately $11 \mathrm{~km}(7 \mathrm{mi})$ south of RWMC and from four representative areas at the RWMC SDA. These include active areas, Pad A, inactive areas, and previously flooded areas. NonCERCLA plant monitoring is conducted as described in ICP PLN- $720^{28}$ and associated procedures. Three composite samples are collected from each of the four representative areas as follows: crested wheatgrass in odd-numbered years, Russian thistle in even-numbered years, and either rabbitbrush or sagebrush (perennials) in odd-numbered years. All biotic samples are analyzed by gamma spectrometry. Radiochemistry is performed on at least one sample from each of the major areas.

Biota sampling is performed as part of the CERCLA Long-Term Ecological Monitoring Program to verify that the remedial objectives of each CERCLA ROD are maintained and that any contamination left in place remains within acceptable limits. Vegetation harvested at each selected location includes leaves, small stems, and inflorescences for sagebrush, and leaves, culms, and inflorescences for grass. The intent of this sampling is to gather the plant material most likely to be browsed by herbivores.

Selected mammal species are obtained and analyzed for metals, explosive compounds, and radionuclide activity. Biota samples are collected on an annual basis at locations identified as sites of concern; actual sample locations are not depicted on Figure 4-11 because they can be extensive and vary within each area. These samples are monitored for both radiological and nonradiological contaminants. Sampling activities are conducted in accordance with INEEL/EXT-02-01191 ${ }^{47}$. 


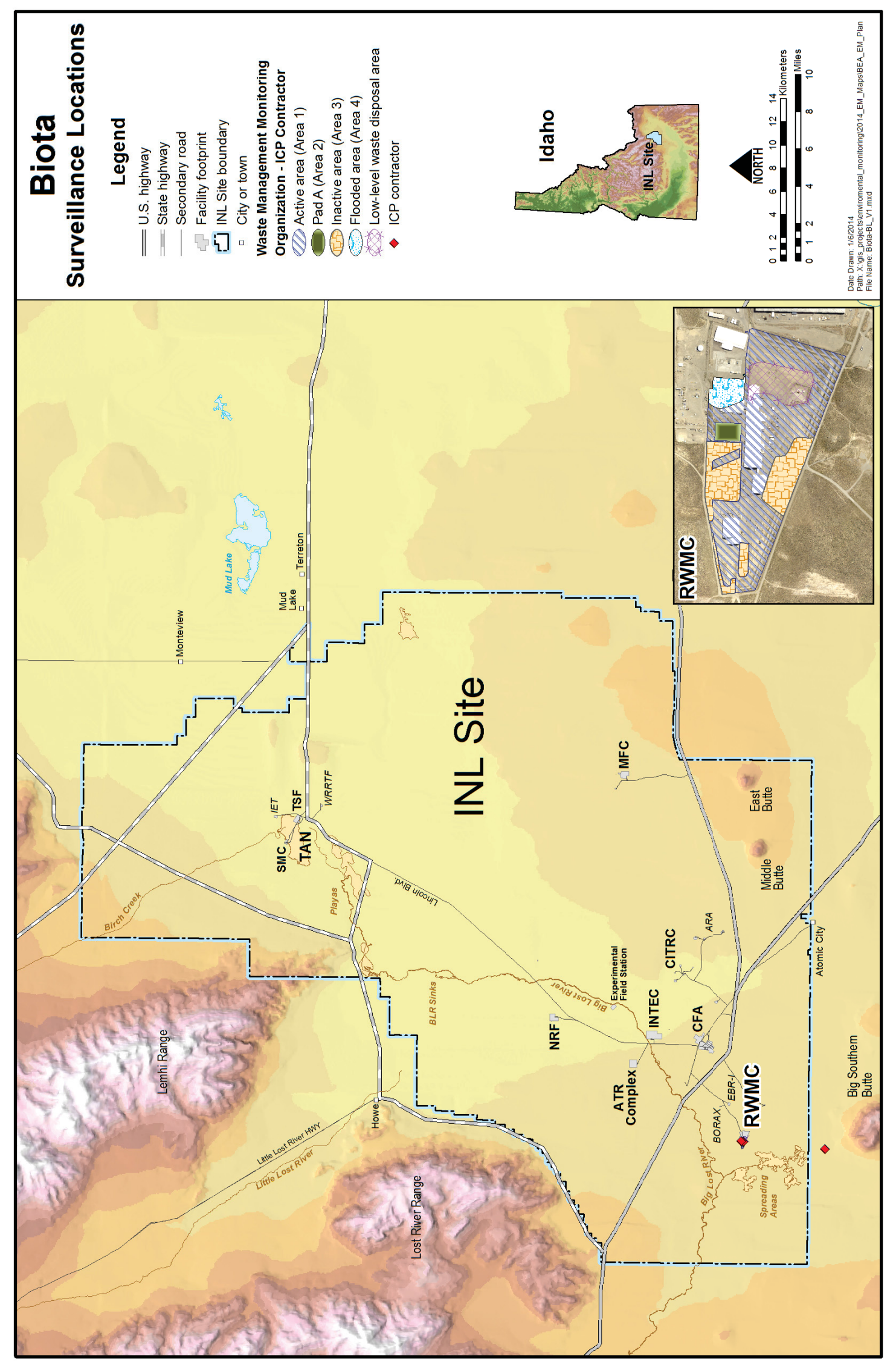

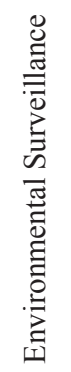

$\frac{9}{7}$ 


\subsubsection{ESER Contractor}

Because large game animals (pronghorn, mule deer, and elk) are wide ranging and are a popular food source for many area residents, the ESER Program collects samples of game animals that are killed on roadways on or near the Site. The collection of large game animal samples is described in the ESER Environmental Program large game animal sampling procedures ${ }^{37}$. The thyroid and samples of muscle and liver tissue are collected from each animal and analyzed for radioactivity. Figure 4-12 shows locations where ESER big-game samples have been collected in the past. These locations vary from year to year depending on the numbers and locations of big-game/motor vehicle accidents.

The ESER Program also collects waterfowl on an annual basis from liquid waste disposal ponds on the Site and from off-Site control areas. Ponds sampled may include the MFC Industrial and Sanitary Sewage Lagoons, ATR Complex sewage lagoon, and an off-Site location. Past results indicate waterfowl may use the hypalon-lined pond at ATR Complex, but no sampling is conducted there. Edible tissues, viscera and remaining tissues (feathers, skin and bones) from waterfowl are each analyzed for gammaemitting radionuclides.

Ecological studies, such as population surveys (on birds and mammals) and community structure surveys (on soil, fauna and plants) are performed by the ESER Program at varying times during the year as described in Section 4.9 (Figure 4-13). 


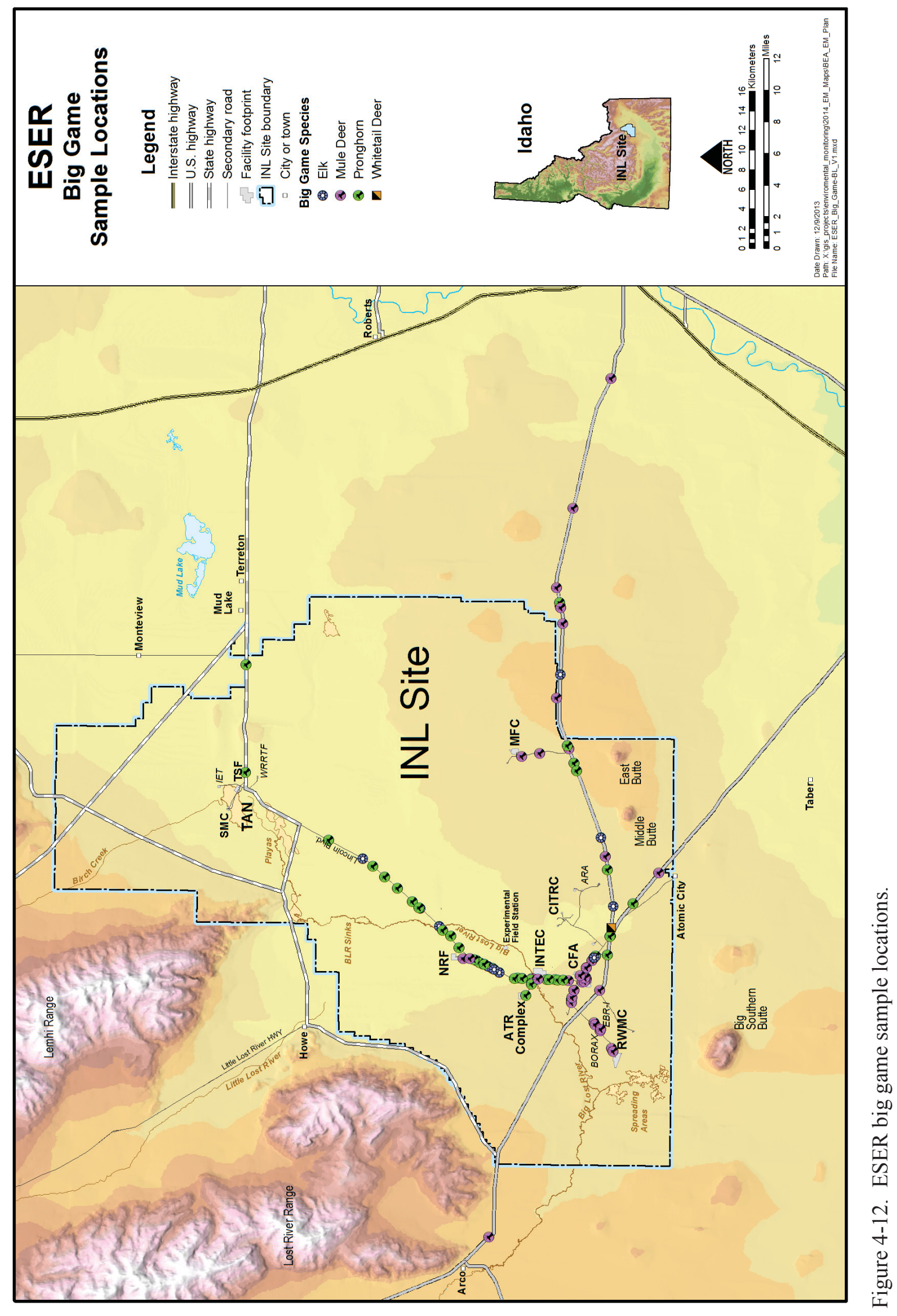




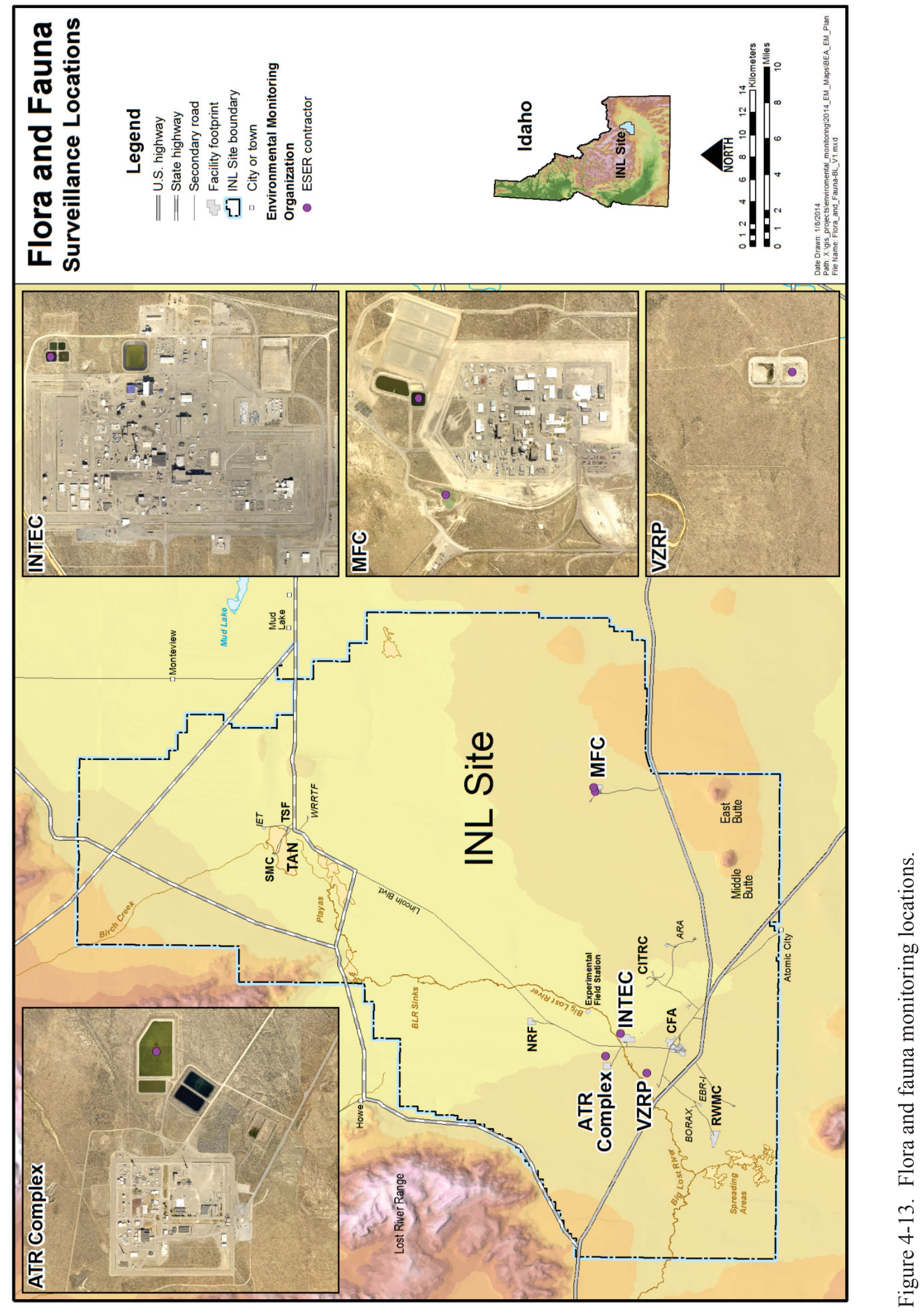




\subsection{Agricultural Products}

The INL Site is located in a large agricultural area that produces products that are economically important to the state. These food products are monitored because they are a direct route of human exposure through ingestion. Milk, meat, and produce may become contaminated via atmospheric deposition, irrigation using contaminated water, and livestock ingesting contaminated water or feed. Figure 4-14 shows the locations where agricultural products are monitored. The ESER Program performs most of the agricultural monitoring in the vicinity of the INL Site. The agricultural products monitored are chosen because they are commonly consumed and are readily available for radionuclide analysis. The ESER Environmental Program procedures for milk, lettuce, wheat, potatoes, and alfalfa sampling provide details for the collection and processing of agricultural products ${ }^{40}$.

\subsubsection{Milk}

Milk is monitored at off-Site locations because it is a potential pathway to the public for radioactive materials from the INL Site activities, particularly radioiodine and strontium-90. Some samples are taken from single-family dairies; others are taken from commercial dairies. A dairy in Idaho Falls is sampled weekly; the rest are sampled monthly.

\subsubsection{Lettuce}

Lettuce from portable lettuce growers and local gardeners is collected at selected locations annually to measure the uptake of radionuclides from soil and deposition from air and because they are a part of the typical diet. Lettuce is a broad-leaf crop which is known to be a good interceptor of radionuclides in airborne particulates. Samples are analyzed for gamma-emitting radionuclides and Sr-90.

\subsubsection{Potatoes}

Although potatoes were not generally considered to be as good an indicator of radionuclide uptake as leafy vegetables, routine potato sampling was resumed in 1994 due to public interest in Idaho's most famous product. Potato samples are obtained annually from warehouses in the vicinity of the Site during harvest. Potatoes are also obtained from friends and relatives living out of state from areas as distant as Maine and Alaska to serve as control samples.

\subsubsection{Wheat}

Wheat is sampled because it potentially represents a major part of the typical diet. Wheat samples are collected and processed from a number of areas in southeastern Idaho. These samples are collected annually during harvest time at local grain elevators.

\subsubsection{Alfalfa}

Because milk cows could eat hay potentially contaminated by releases from the INL Site, alfalfa is collected downwind of the INL Site from a rancher in Mud Lake. It is analyzed for gamma-emitting radionuclides.

\subsection{External Radiation}

External (or penetrating) radiation is measured using radiation dosimeters, pressurized ion chambers, and gamma radiation detectors at facilities, roadways, and surrounding communities. Sources of external radiation include natural radioactivity, cosmic radiation, fallout from nuclear weapons testing, radioactivity from fossil fuel burning, and radioactive effluents from INL Site operations. The contribution of INL Site operations to background radiation exposure is determined by comparing exposures measured at the Site boundary locations to those at distant locations. Figure 4-15 shows the 
regional external radiation monitoring locations, and Figure 4-16 shows detailed on-Site monitoring locations.

Radiation monitoring is performed at the INL Site to:

- Characterize penetrating radiation levels at specific points of interest at waste management facilities and at the perimeter of Site facilities

- Detect and report significant trends in measured levels of penetrating radiation.

To meet these objectives, INL Site contractors measure gamma radiation exposure rates and cumulative exposures and perform gamma-radiation surveys both on-Site and off-Site.

Environmental dosimeters are used to measure cumulative exposures to ambient penetrating radiation for monitoring locations. The dosimeters measure changes in ambient exposures possibly attributed to handling, processing, transporting, or disposing radioactive waste. The dosimeters are located along major highways, in surrounding communities, and around the perimeter fences of each major facility. The

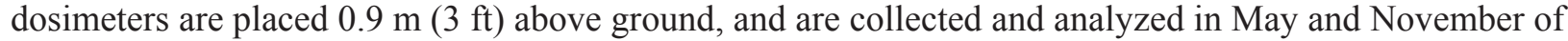
each year to determine background exposures resulting from natural terrestrial sources, cosmic radiation, and fallout from testing nuclear weapons.

In addition to environmental dosimeters, a global positioning radiometric scanner (GPRS) system is used to conduct gamma-radiation surveys. These surveys measure gross gamma radiation and are used to identify general areas of radioactivity. They differ from the in situ soils analysis discussed in Section 4.5.1, which are used to identify specific radionuclides and activity levels. Gamma-radiation surveys are used to screen soils that have become contaminated with gamma-emitting nuclides and to detect penetrating radiation exposures outside the fenced areas from a variety of possible sources inside the facility.

The primary purpose of the ESER external radiation monitoring program is to assess the actual external radiation dose to an individual living at the INL Site boundary and to members of the public living beyond the INL Site boundary within 50 miles of any Site facility.

The GPRS is mounted on a four-wheel drive vehicle. Annual gamma-radiation surveys are conducted around the perimeter of selected facilities on an annual schedule to document penetrating radiation fields. Two plastic scintillation detectors identify contaminated areas, and both the global positioning system and radiometric data are recorded. Because these surveys involve facility perimeters, these monitoring locations are not displayed on either of the external radiation figures. 


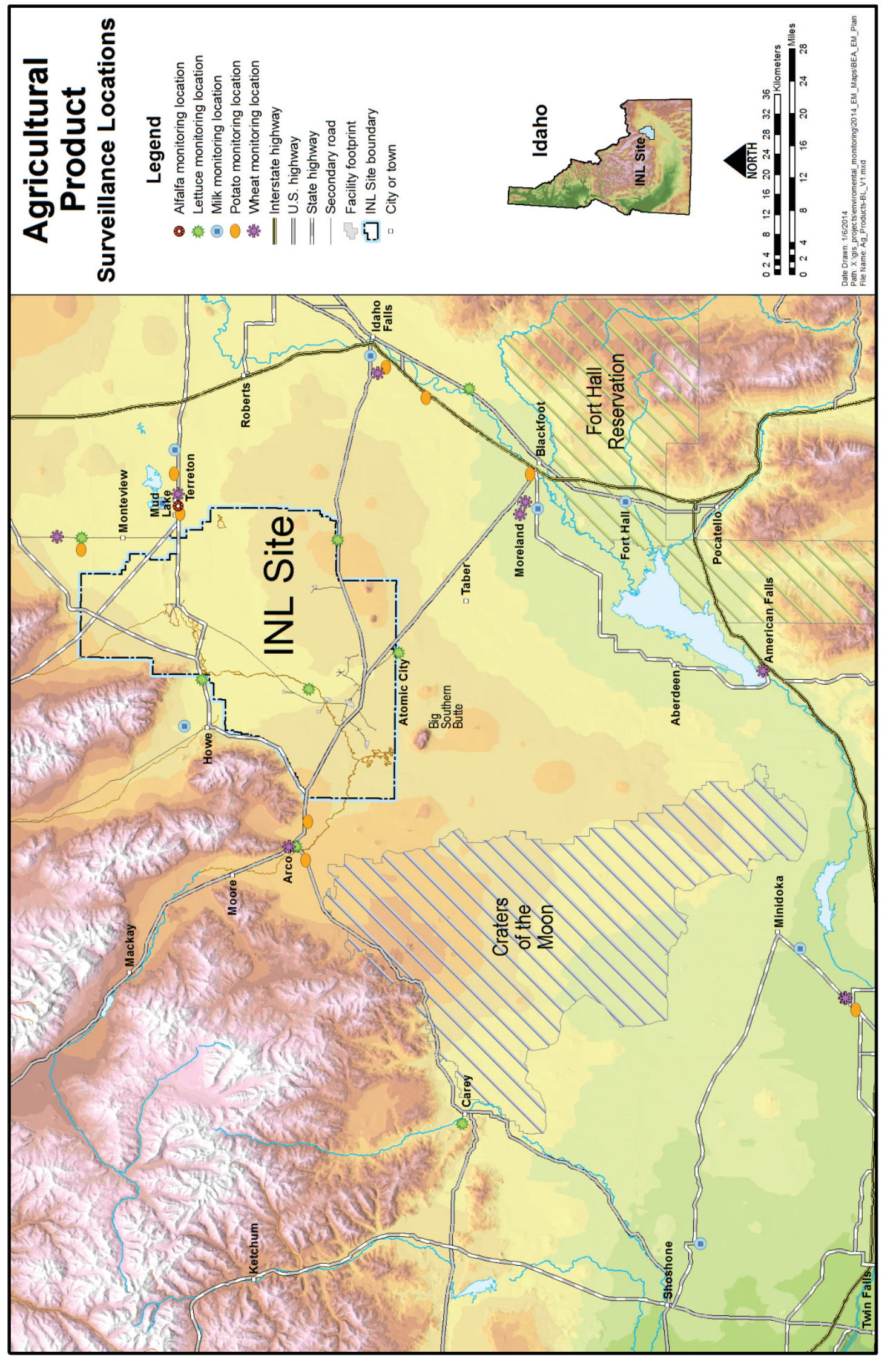

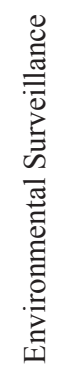

. 


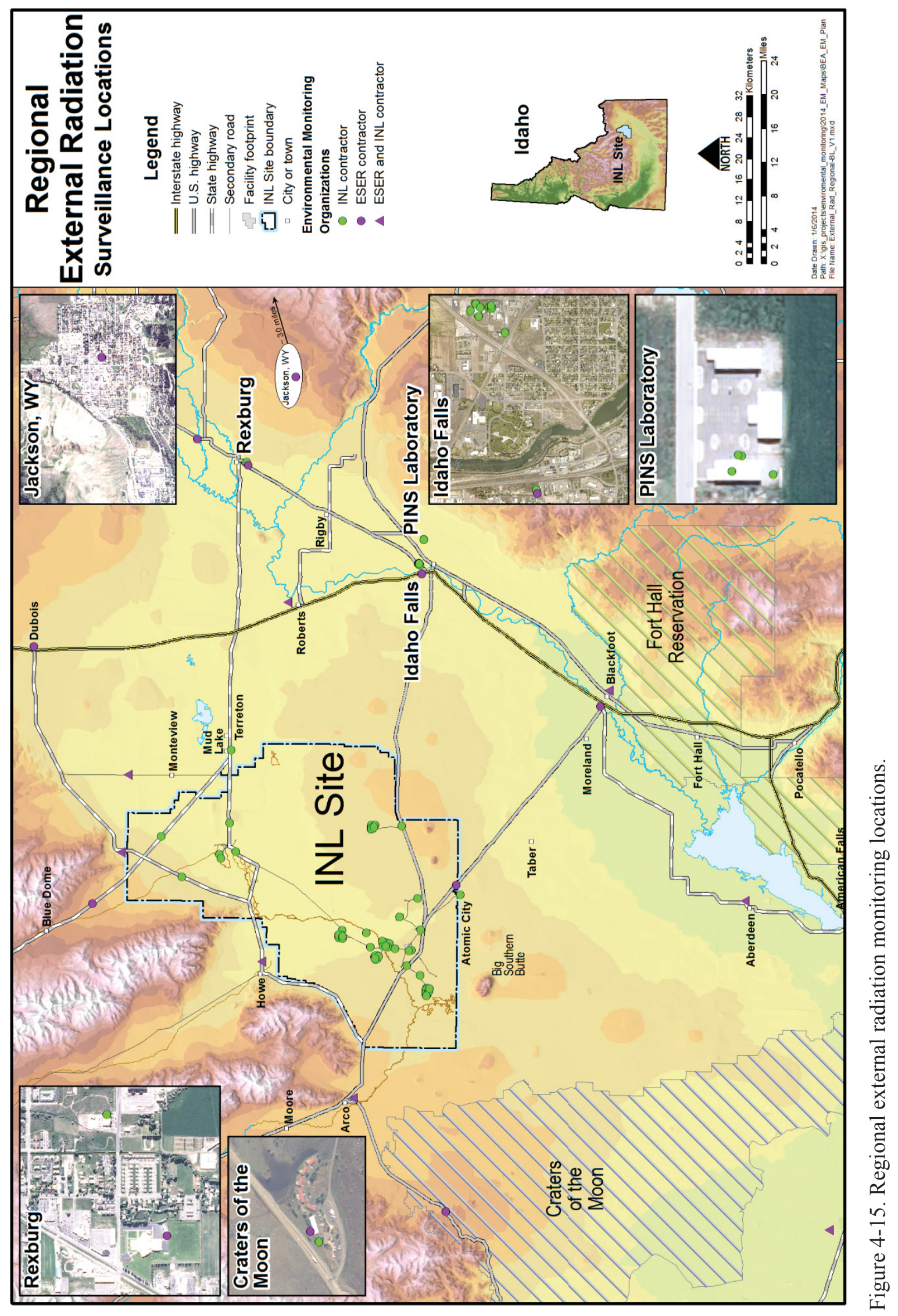




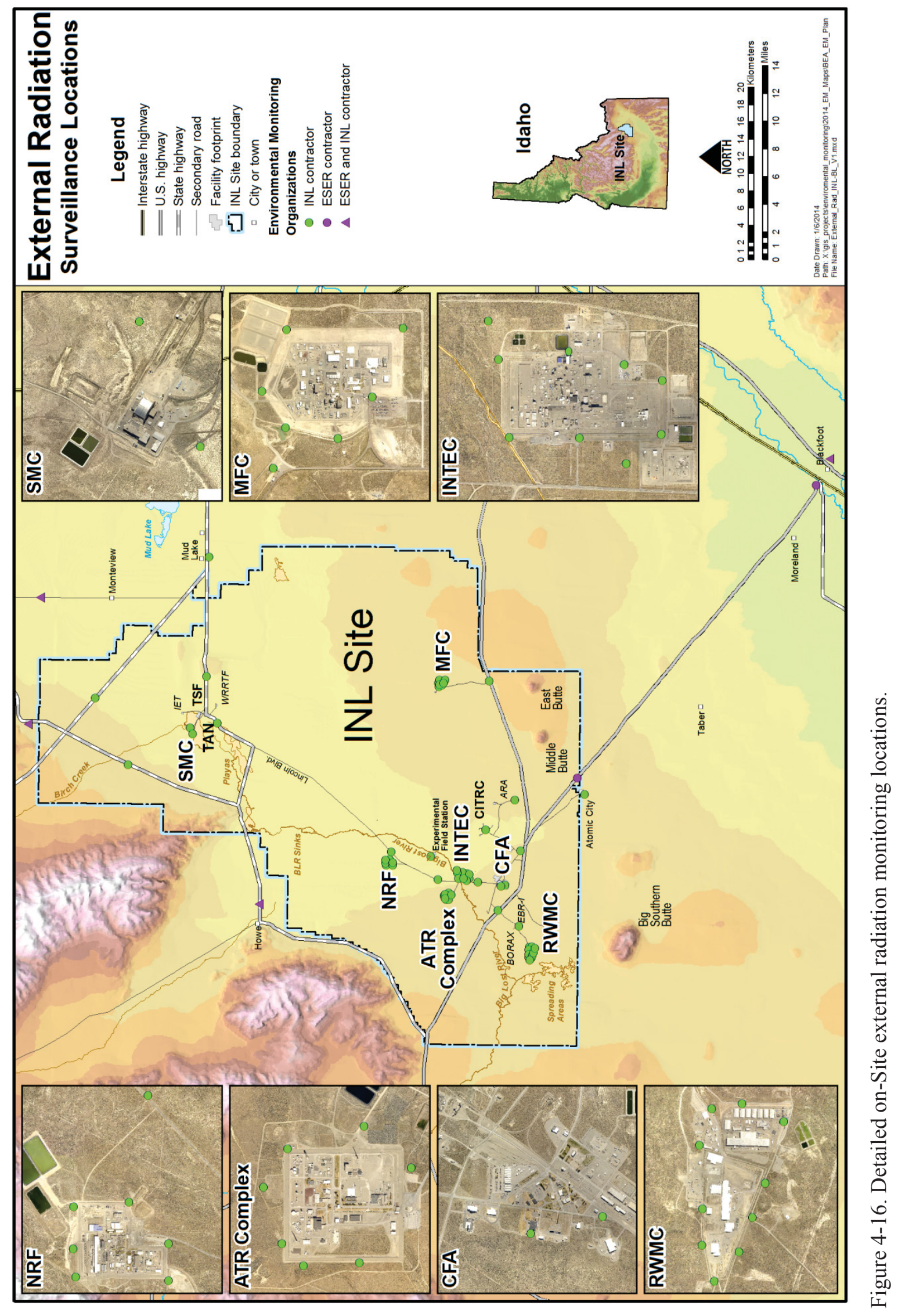




\subsubsection{INL Contractor}

External radiation monitoring is performed by the INL contractor as described in the PLN-8510 37 and associated procedures. Environmental dosimeters are maintained at locations on the Site along major highways, around the perimeter fences of each major facility, and at off-Site locations.

A GPRS is used for Sitewide radiological monitoring and Sitewide emergency response. The GPRS units used are primarily for collecting long-term stewardship data and yearly monitoring of gross radiation levels at Site perimeters and roadways. These data are used to identify and analyze year-to-year trends.

\subsubsection{ICP Contractor}

External radiation monitoring is performed by the ICP contractor as described in ICP PLN-720 28 and associated procedures. Annual surveys are conducted per DOE Order $435.1^{3}$ compliance requirements for detecting gross gamma radiation at the RWMC SDA and around the Idaho CERCLA Disposal Facility. The survey is conducted using a vehicle mounted GPRS. The system utilizes a Trimble Global Positioning System and two plastic scintillation detectors connected to a personal computer on-board the vehicle. The GPRS information data are differentially corrected and transmitted via satellites, and geographic coordinates (latitude and longitude) are recorded at least every two seconds. The vehicle is driven less than or equal to 5 miles per hour, with the detector height at 36-in above the ground.

\subsubsection{ESER Contractor}

The ESER Program monitors external radiation at seven Site boundary and ten off-Site locations (Figure 4-16) using environmental dosimeters. Two kinds of dosimeter systems are currently usedoptically stimulated dosimeters (OSLDs) and thermoluminescent dosimeters (TLDs). OSLD technology is relatively new and involves absorption of ionizing radiation energy by trapping electrons which are excited to a higher energy band. The trapped electrons in the OSLD are released by exposure to a green light from a laser. TLDs have historically been used and involve crystals with impurities which when exposed to ionizing radiation are excited to higher states and remaining there at normal ambient temperature. When TLDs are heated, electrons are released into the in the form of photon energy which is measured with photomultiplier tubes. The crystal then returns to the lower state of energy. The primary advantage of OSLD technology compared with TLD technology is that the nondestructive reading of the OSLD allows for multiple readings of the dosimeter.

An OSLD and TLD is placed at each location one meter above the ground surface. The dosimeters are changed semiannually, normally in early May and again in early November. Conversion to OSLDs began in November 2010 when they were placed side-by-side with existing thermoluminescent dosimeters (TLDs). Both kinds of dosimeters continue to be used in order to provide a comparative data base prior to converting completely to OSLDs.

The Operational Dosimetry Section of the ICP contractor analyzes the TLDs. The four chips are read separately and a mean response is determined for each set. This value is converted to the exposure in milliroentgen based on a detailed calibration procedure. Dosimeter data are interpreted by comparing exposures measured at the boundary locations to those at distant locations.

The OSLDs are analyzed by the Idaho State University Environmental Assessment Laboratory.

\subsubsection{NOAA}

The NOAA ARLFRD is primarily responsible for meteorological monitoring at the Site (see Section 5). In the past, ARLFRD maintained its own external radiation sensors at the towers in the meteorological monitoring network, but these have been deactivated. All external radiation sensors on the NOAA towers are owned and maintained by other organizations as described in other parts of this section. 
ARLFRD collects these data together with the meteorological data so that the information can be simultaneously displayed using ARLFRD's meteorological display tool that is described in a following section. The ARLFRD's primary role with these sensors is to collect and display the data in near-real time.

\subsection{Ecological Monitoring}

The ESER Program conducts an array of ecological activities on the Site to provide ecological and natural resources support to DOE-ID for land management issues and to supply ecological information and expertise to support activities that affect natural resources. These activities include wildlife and vegetation surveys, revegetation, weed management, assessing potential impacts to ecological resources, and facilitating ecological research on the Idaho National Environmental Research Park.

Specific ecological monitoring work at the Site involves collecting data related to the abundance and distribution of certain species or groups of species. Results provide information on ecological conditions and trends at the Site that are used to:

- Provide assessments of the condition and trend of INL Site ecological resources

- Assess compliance with federal and state regulations

- Provide assessments of the likely impacts to ecological resources from human-caused or natural disturbances

- Propose mitigation for minimizing adverse impacts to ecological resources from Site activities

- Support the long-term stewardship goal of conserving ecological resources

- Provide baseline data to support ecological research opportunities at the Idaho National Environmental Research Park.

Ecological monitoring data are provided in various technical reports and presented on the ESER web site athttp://www.gsseser.com/. The data are reported to DOE-ID and various state and federal natural resource and agricultural agencies with whom the ESER Program collaborates.

\subsubsection{Native Vegetation and Invasive Plants}

Long-term vegetation plots were established in 1950 to monitor the potential effects of activities at the INL Site on ecological resources. Although they were established for that specific purpose, vegetation plots now provide one of the most significant data sets for understanding vegetation dynamics in sagebrush steppe. These plots are among the most intensive and scientifically rigorous efforts by any agency to document long-term changes in sagebrush steppe. This monitoring provides information on plant community-level changes at a landscape level. Initially, 100 permanent plots were established on two intersecting transects (Figure 4-17). These plots are surveyed at 5-year intervals. Data collected at each plot include cover by line intercept and point interception frame and density and frequency.

Beginning in 2013, additional vegetation data is collected to characterize habitat quality for sage grouse. Two hundred twenty-five plots are monitored on a three-year rotation to provide information on abundance and distribution of native and non-native plants. Additional surveys are conducted annually to inventory areas dominated by non-native annual grasses. 


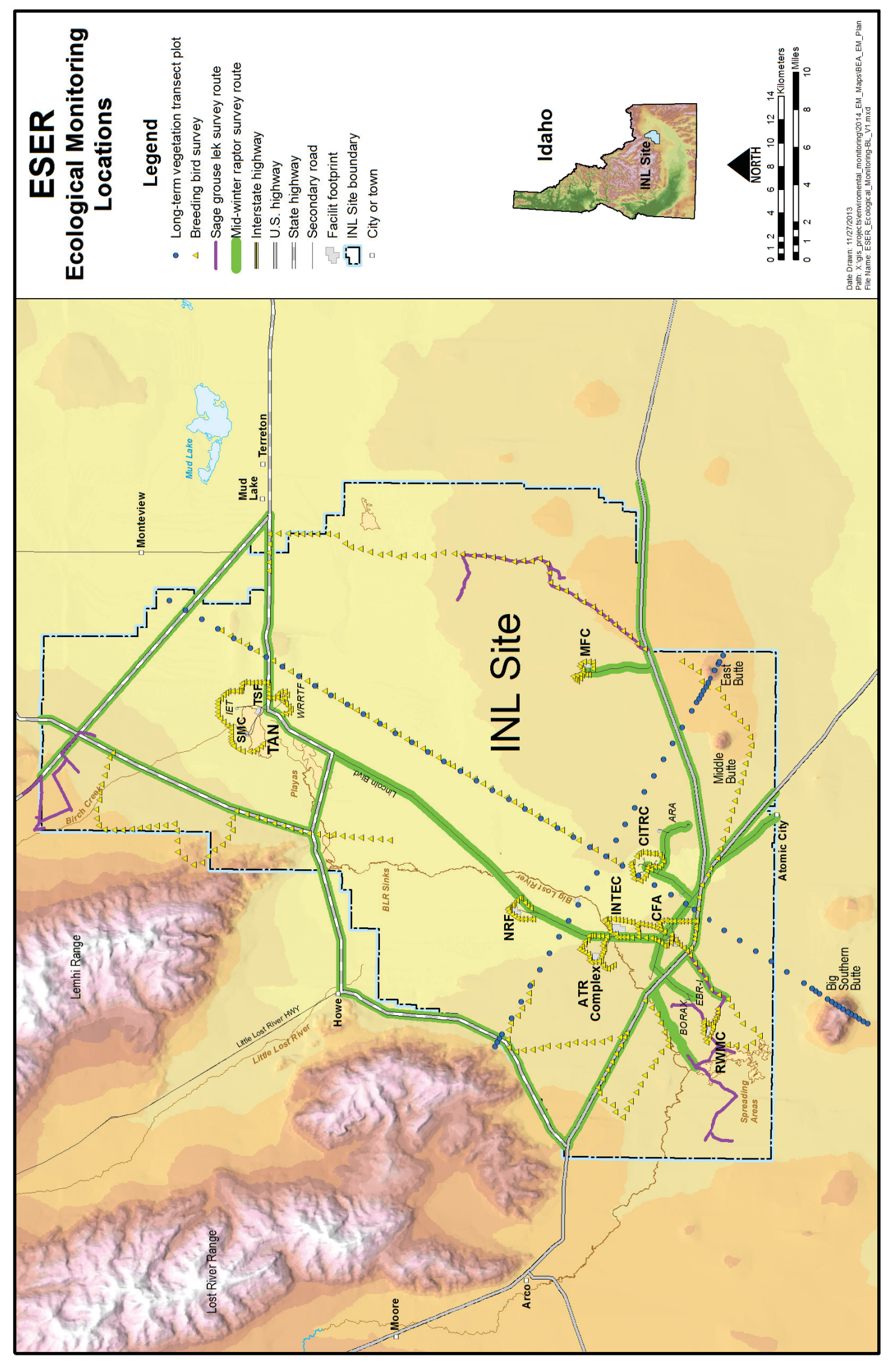

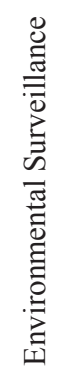

$\stackrel{\circ}{7}$ 


\subsubsection{Mammals}

Large mammal surveys through 2009 were conducted in January and July each year to estimate abundance and distribution of elk, deer, and pronghorn antelope. The surveys were done from the air on a representative sample of transects. Data were collected in a manner that is comparable with those collected by neighboring agencies (Idaho Department of Fish and Game, Bureau of Land Management, and U.S. Forest Service for example). From 2010 through 2012 the scope of the big game surveys was changed from conducting flights across the INL Site to placing global positioning system collars on elk. This study provided defensible and reliable data for NEPA documents and enable a more complete and reliable assessment of impacts from infrastructure development, roadway accidents, and wild fires. This study provided information on migratory corridors, agricultural area use, contaminant area use, and evaluation of potential radionuclide contamination of human receptors off the INL Site.

Recently, white-nose syndrome (WNS) has been identified as a major threat to many bats that hibernate in caves. WNS is a disease caused by a cold-adapted fungus (Geomyces destructans). Since its discovery in 2006, transmission of WNS has expanded 1,200 km (746 miles) from New York to Oklahoma, and researchers estimate that the spread of WNS syndrome will continue. WNS has killed at least 5.5 to 6.7 million bats in seven species. This disease has been labeled by some as the greatest wildlife crisis of the past century, and many species of bats could be at risk of significant declines or extinction due to this disease. Several species of bats on the INL Site could be affected by WNS. One of these species (little brown myotis [Myotis lucifugus]) has been petitioned for emergency listing under the Endangered Species Act (ESA). Two species that occur on the INL Site (western small-footed myotis [Myotis ciliolabrum] and western long-eared myotis [Myotis evotis]) are the western counterparts of the eastern small-footed myotis (M. leibii) and northern long-eared myotis (M. septentrionalis). The status of the latter two species is currently being reviewed for potential listing under the ESA. Therefore, the ESER Program developed and initiated a bat monitoring program on the INL Site in collaboration with the U. S. Fish and Wildlife Service and Idaho Department of Fish and Game.

\subsubsection{Birds}

The DOE is preparing a Candidate Conservation Agreement (CCA) for Greater Sage grouse which are under consideration for protection under the Endangered Species Act. Sage grouse populations on the INL Site are monitored annually by surveying their use of leks on three routes. Breeding and nesting generally occurs within two miles of leks. Sage grouse lek routes (Figure 4-17) are monitored weekly for a minimum of 4 weeks beginning in March. The surveys are conducted by visiting those leks at dawn and counting the number of individual birds. The methods used provide comparable data to those collected by neighboring agencies and the data collected are shared with them. As part of the CCA, additional lek surveys are conducted in the spring to identify all active leks on the INL Site.

Beginning in 2012, raven nests have been inventoried and monitored for nest success. Ravens have been reported to be important predators on sage grouse eggs and chicks. Ravens often use infrastructure as nesting sites. These include buildings, power poles, chimneys, stacks and other vertical structures. Monitoring to determine raven nest locations can be used to develop nest deterrents.

Raptors are surveyed annually on the Site through mid-winter raptor counts in collaboration with the United States Geological Survey Biological Resources Division (USGS-BRD). Raptor populations tend to fluctuate with slight changes in the environment, such as prey availability and weather conditions. Therefore, they are often used as environmental indicators to determine effects of human development on the environment and the general health of the ecosystem. Site raptor surveys are conducted in conjunction with the nationwide USGS-BRD Mid-winter Bald Eagle Survey. The ESER Program surveys two official USGS-BRD Mid-winter Bald Eagle Survey routes (Figure 4-16). In addition to surveying for bald eagles, ESER surveys include all eagles, hawks, falcons, shrikes, owls, ravens, crows, and magpies. 
The Breeding Bird Survey (BBS) is a large-scale survey of North American birds. It is a roadside route survey of avifauna designed to monitor abundance and distribution of birds primarily covering the continental U.S. and southern Canada. It is administered by the USGS-BRD. These surveys yield useful information about population dynamics, effects of weather and fire on avian abundance, effects of INL Site operations on avifauna, and the breeding status of a number of bird species of concern, including sagebrush obligate species and other species exhibiting declines throughout their range. Thirteen BBS routes are surveyed on the Site (Figure 4-17). Five remote routes are standard 40-km (25 mi) BBS routes, data from which are reported to the USGS-BRD annually. These routes traverse the remote areas of the INL Site and include major habitat types throughout the Site. Eight facility routes are located in and around major Site facility complexes. Each remote route consists of 50 stop locations at approximately 0.5 -mi $(0.8 \mathrm{~km})$ intervals. Facility routes consist of $18-60$ stop locations at approximately $0.2-\mathrm{mi}$ $(0.32 \mathrm{~km})$ intervals. The data collected are comparable to those collected by other neighboring agencies. 


\section{METEOROLOGICAL MONITORING}

The meteorological monitoring program supports laboratory-wide environmental monitoring activities as well as emergency response. Short- and long-term weather conditions have a substantial effect on the INL Site environment, particularly with respect to the movement of contaminants in air and the groundwater system. Meteorological monitoring is performed to record weather conditions such as wind speed and direction, temperature, and precipitation so that this information may be used with predictive models to estimate the concentration of contaminants after they have been released to the environment. Meteorological monitoring results are also used to plan environmental measurement programs or for modeling required for compliance with air quality regulations. For example, the Site contractors perform modeling to show compliance with ambient air quality regulations and to comply with requirements to estimate off-Site dose (see Section 9 for a discussion of dose assessment modeling). Figure 5-1 shows the meteorological monitoring locations.

Results of past work related to the tower network are summarized in DOE-ID- $12118^{6}$, and DOE-ID$12119^{35}$.

\subsection{NOAA}

Meteorological services and supporting research are provided to the INL Site by the NOAA ARLFRD. The ARLFRD provides real-time meteorological data, climatological data, weather predictions, and dispersion calculations for routine operations and emergency response.

The ARLFRD operates a meteorological monitoring network that covers an area of approximately $3,885,000$ hectare $\left(15,000 \mathrm{mi}^{2}\right)$ to characterize the meteorology and climatology of the INL Site. The network consists of 35 meteorological towers both on and around the Site. Most of the towers are $15 \mathrm{~m}$ $(50 \mathrm{ft})$ tall and take wind speeds and direction measurements at $15 \mathrm{~m}(50 \mathrm{ft})$, temperatures at $2 \mathrm{~m}$ and $15 \mathrm{~m}(6$ and $50 \mathrm{ft})$, and relative humidity at $2 \mathrm{~m}(6 \mathrm{ft})$ above ground level. Three taller towers range from $46 \mathrm{~m}$ to $76 \mathrm{~m}$ (150 ft to $250 \mathrm{ft}$ ) high and are instrumented at multiple levels. Many towers have additional sensors for precipitation, solar radiation, and barometric pressure. All the tower measurements are averaged over 5-minute periods and transmitted to ARLFRD in near real-time via radio-frequency communication.

In addition to the meteorological towers, ARLFRD operates a 915-MHz radar wind profiler with a Radio Acoustic Sounding System at a site just north of INTEC. These systems provide wind speed and direction profiles up to about $4 \mathrm{~km}(2.5 \mathrm{mi})$ above ground level and temperature profiles up to about $1 \mathrm{~km}$ $(0.6 \mathrm{mi})$ above ground level, thereby providing crucial information about winds and temperatures aloft. More recently, ARLFRD added a minisodar system capable of providing high-resolution wind and turbulence measurements up to $200 \mathrm{~m}(650 \mathrm{ft})$ above the ground.

The ARLFRD has also developed a program called INLViz to display data in near real-time from the tower network and the vertical profilers. INLViz has been installed at many office locations both within and outside the INL Site. At this time INLViz is being phased out in favor of web-based displays of the network data. A real-time display of the meteorological data is publicly available on the Internet at http://www.noaa.inel.gov/windV/windV.asp. In addition, ARLFRD now maintains an INL Site Weather Center at http://niwc.noaa.inel.gov that provides a range of meteorological information relevant to the INL Site. 


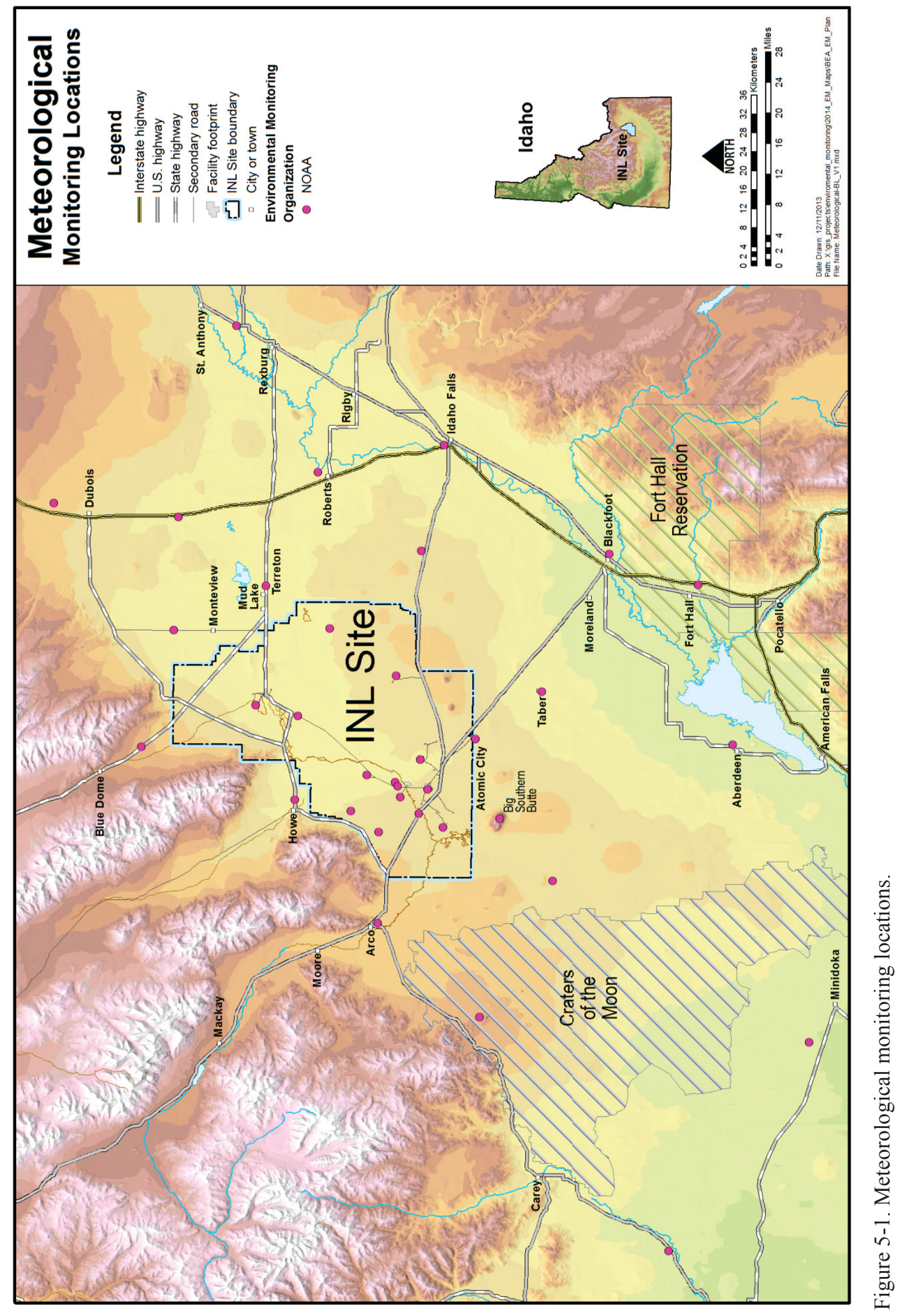




\section{ENVIRONMENTAL EVENT MONITORING}

Environmental event monitoring is an essential part of safe operations because of the potential impacts a release of radioactive or regulated materials from Site facilities, either from unplanned/accidental operational events or natural events, could have on the environment and the public. Environmental events at the Site can be widespread (e.g., a wildland fire spread by high winds) or facility-specific (e.g., a chemical spill limited to a small area immediately around the spill). Data from event-specific monitoring are used to evaluate the potential impact of an event to personnel, the environment, and the public.

Responses to environmental events vary depending on the severity of the event and are conducted by the responsible contractor. The INL contractor responds to all events. Figure 6-1 shows the locations of samplers specifically intended for use during an environmental event. Locations of portable or routine samplers are not shown.

\subsection{Response to an Emergency or Unplanned Release}

The INL Site has an extensive program to identify chemical/radioactive hazards, evaluate associated risks, prevent accidental releases, and respond appropriately in the event of a release. This comprehensive INL Site Emergency Preparedness Program is addressed in PLN-114, INL Emergency Plan/RCRA Contingency Plan ${ }^{50}$. The Plan is used by the Emergency Response Organization and other trained personnel in the event of an emergency and provides the overall process for responding to and mitigating consequences of emergencies that might arise at the Site. Emergency plans for the INL Site consolidate all emergency-planning requirements for federal, state, and local agencies. Mutual aid agreements are in place between the INL and state and local agencies to respond to emergencies. One such agreement allows local fire departments to respond to fires on the Site and allows the INL fire department to respond to fires off-Site.

In the event of an emergency or unplanned release, anthropogenic or natural radioactivity can be released into the air. These releases could result from direct atmospheric release from a facility, or by redistribution by fire or winds of anthropogenic or natural radioactivity contained in soil and vegetation. During such events the INL contractor collects field data. Data collected include readings of penetrating radiation levels, airborne and surface contamination levels, and radiation surveys outside of facility fences. Three types of air samples can be taken during environmental events that are declared operational emergencies or which involve soil contamination areas:

- Immediate short-term "grab" samples

- Stationary 24-hour samples at strategic locations specific to the event

- Routine environmental samples taken at standard locations (continuous monitoring).

Field data results are reported to the Emergency Response Organization.

The Plan also includes spill prevention and response requirements for each facility. Spills and releases are reported to the Spill Notification Teams. The Spill Notification Teams determine if the spill or release is reportable and provides assistance to operations for making appropriate release notifications.

\subsubsection{AMWTP}

Spills or releases greater than a reportable quantity or permit limit are reported to the state and federal authorities as required. The AMWTP also has a Spill Response Procedure (AMWTP-MP-EC\&P-7.10) ${ }^{51}$ 
and an Advanced Mixed Waste Treatment Project Emergency Plan/RCRA Contingency Plan (AMWTP-MP-EP\&C-12.1) ${ }^{52}$.

AMWTP has installed ANSI N13.1 $1^{24}$ compliant monitors with alarms on two stacks at the AMWTP. If the stack monitors initiate an alarm, AMWTP will respond using a graded approach to minimize the release by switching filter banks and/or shutting down the processes.

\subsubsection{ICP}

The ICP Spill Notification Team is responsible for release notifications in accordance with federal and state regulations, DOE orders, executive orders, and company requirements. The ICP Spill Notification Team provides 24-coverage. The team documents all spills, determines if releases are reportable, documents required information, determines thresholds, and makes release notifications within prescribed timeframes.

\subsubsection{INL}

High-volume air samplers owned and maintained by ES\&S are located at some of the ARLFRD towers operated by NOAA. These samplers are intended for use in the event of a radiological accident at the Site and are not used for routine environmental monitoring. Samplers can be turned on and off remotely upon request from DOE-ID by an operator stationed at ARLFRD or in the Emergency Operations Center (EOC).

Short-term grab samples are taken in the field by the ES\&S Monitoring Services organization to provide gross radiation levels for early indication of event conditions. The grab samples are taken using portable high-volume air monitors to assess exposure potentials, verify the effectiveness of on-Site protective actions, and determine the need for off-Site protective actions. The high-volume air monitor locations are selected by the EOC based on wind direction and conditions specific to the event. Highvolume air monitors are capable of drawing large quantities of air through a particulate filter over a short period of time (approximately 15 minutes) and are used to detect gross alpha and gross beta emitting radionuclides. Results of short-term samples are generally available within 1 to 2 hours after samples are collected.

Event-specific monitoring provides data to evaluate potential radiological doses associated with events resulting in accidental or unplanned radiological releases from Site operations or wild fires. During the fire season, the INL contractor temporarily installs high-volume air samplers that can be activated during wildfires in situations where the fire may burn through areas with radiological contamination. Because most events are short term, ambient air is sampled for 24 hours to obtain the required airflow through the samplers and desired detection levels for specific radionuclide measurements. These samplers are not weather-hardened and are used only during the fire season (May through September).

The INL contractor maintains a routine monitoring network of low-volume air samplers at fixed locations that take continuous air samples. Results from these routine environmental samples are used to supplement other event-specific measurements to determine and document the nature and quantity of any radioactive material detected in ambient air on and around the INL Site. 


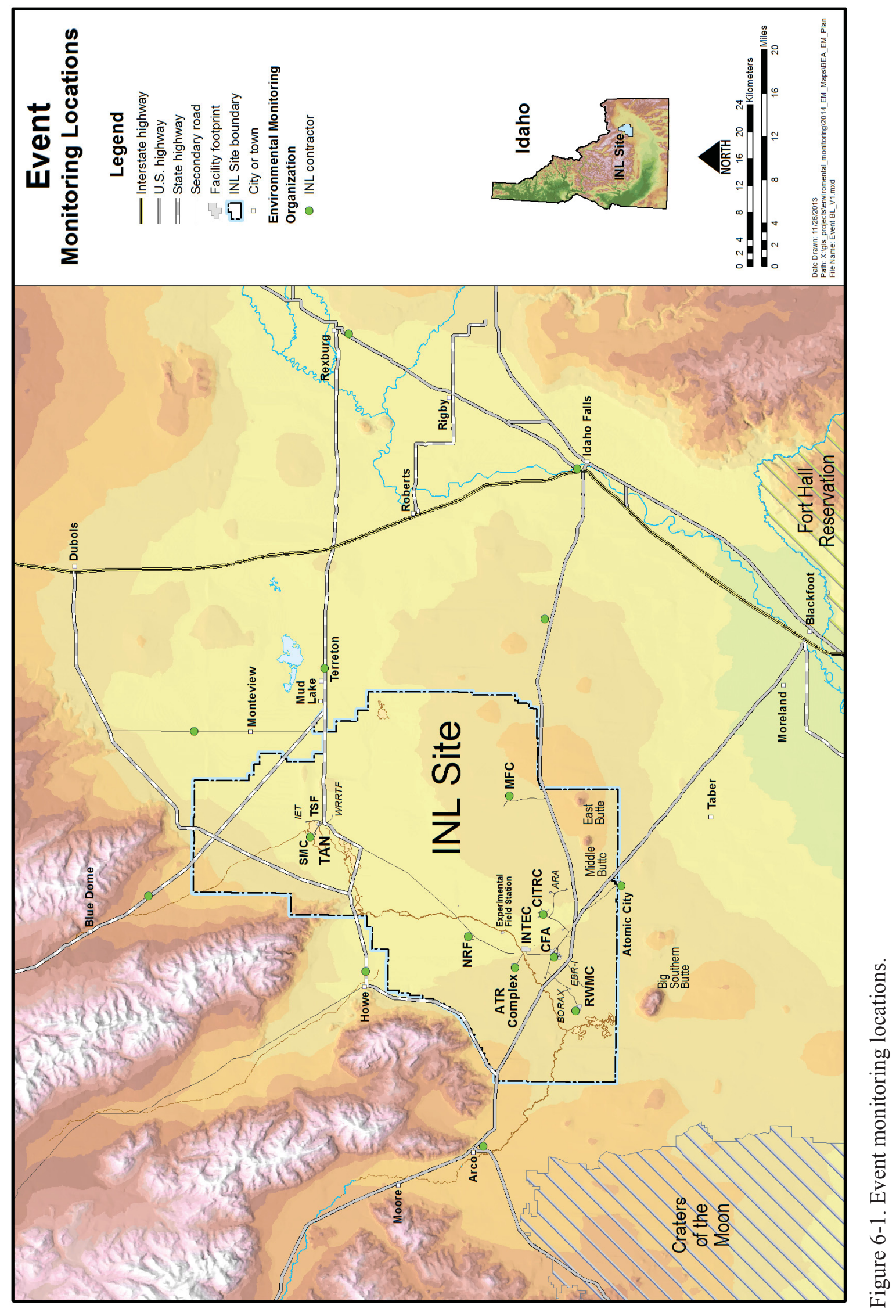




\subsection{Response to an Exceedance}

Each INL contractor maintains their own plans or procedures to ensure that appropriate, timely notifications to appropriate authorities occur and that corrective actions are taken in the event that monitoring results exceed a regulatory limit or, in some cases, a preset trigger level. Specific actions to be taken when validated monitoring results are above certain trigger levels are identified in the applicable permits and regulations (e.g., RCRA, WRP, and Safe Drinking Water Act ${ }^{41}$ ). These actions include reporting any exceedances to the appropriate federal, state, or local agencies, along with initiating appropriate corrective actions in a timely manner. The types of corrective actions could vary depending on the specific regulation and could include follow-up analysis or confirmation sampling, removing potable water well from service, or remedial action.

For reportable occurrences, specific actions to be taken are identified in the DOE Order 231.1B, Environment, Safety and Health Reporting ${ }^{53}$, which establishes reporting requirements and categorizes releases of radionuclide and hazardous substances or regulated pollutants. Taking the following general steps when responding to an environmental data exceedance will ensure that coordinated actions are taken and INL Site stakeholders are notified in a timely manner:

1. Discover, confirm, and make initial notification

2. Categorize environmental data exceedance

3. Determine and initiate appropriate response

4. Complete necessary reporting and notification. 


\section{REPORTS}

General reporting requirements for effluent monitoring and environmental monitoring activities at the INL Site are outlined in DOE Order $231.1 \mathrm{~B}^{53}$ and DOE Order $458.1^{1}$. These orders specify the reporting responsibilities, timing, and distribution of several routine environmental reports. The requirements for preparing and distributing accident-related or unusual occurrence reports are included in DOE Order $231.1 \mathrm{~B}^{53}$.

Following are the principal objectives of DOE's reporting system, as stated in DOE/EH-0173T ${ }^{4}$ :

- Alert DOE management to occurrences for the purpose of investigating and evaluating causes, and identify appropriate measures to prevent recurrences

- Obtain early, complete, and factual information on occurrences as a basis for reports to the Secretary of Energy, Congress, other federal agencies, and the public, as appropriate

- Identify trends in areas of concern for DOE and contractor operations

- Provide a basis for improving codes, guides, and standards used in the DOE and contractor operations

- Monitor, evaluate, and report on-Site discharges, liquid and airborne effluents, and environmental conditions in the vicinity of DOE sites to assess the levels of radioactive pollutants and their impact on the public and the environment

- Comply with regulations and DOE orders.

Compliance monitoring data driven by specific permits or regulatory requirements are reported to federal, state, and local agencies in formats and frequencies specified by the respective regulatory document. Table 7-1 lists effluent and environmental monitoring reports at the INL Site. 


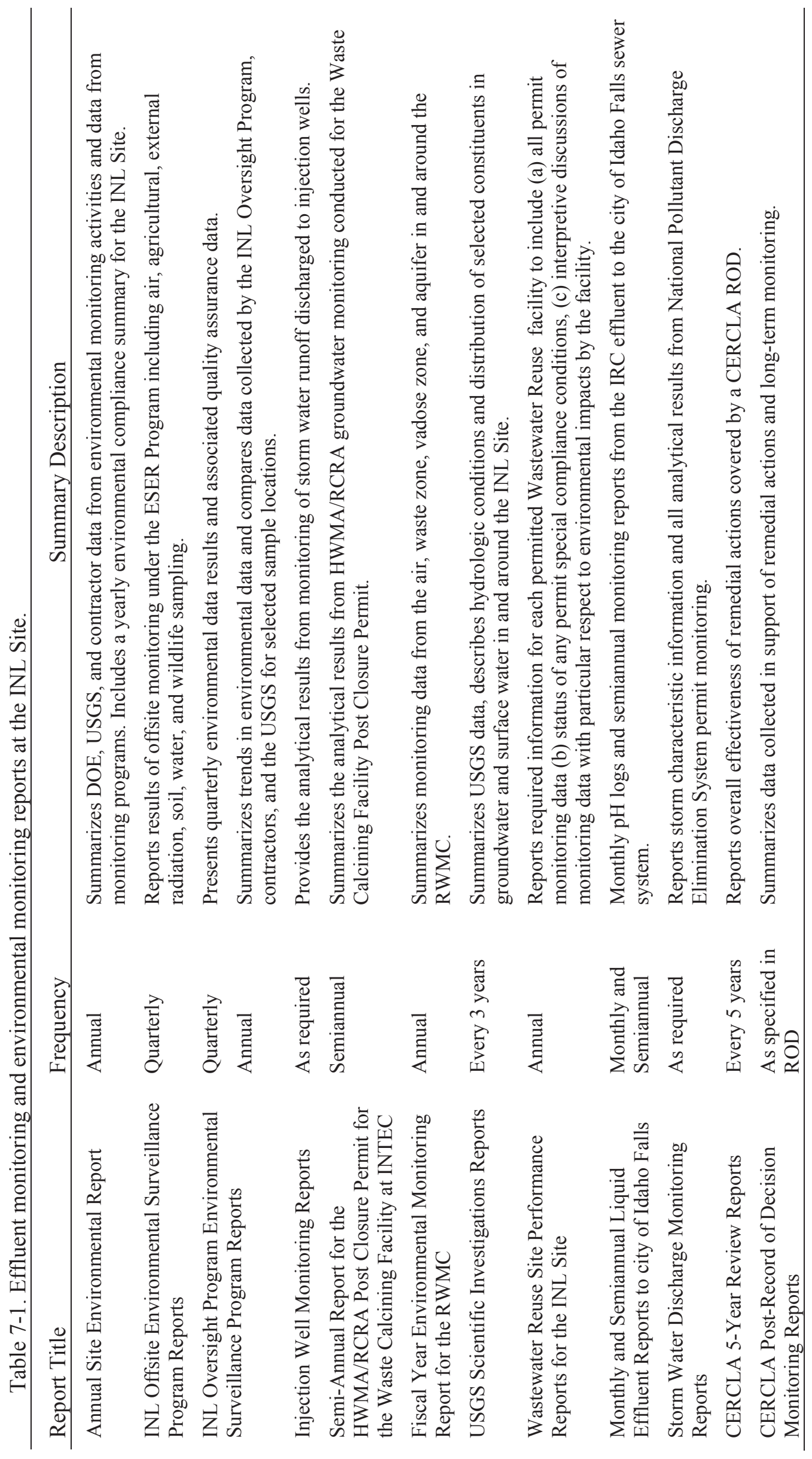




\subsection{ICP and INL Reporting Requirements}

The INL and ICP contractors are responsible for reporting requirements for their respective facilities with regard to:

- $\quad$ Source-specific and Sitewide air permits required for compliance with Public Law 91-604, Clean Air Act Amendments of $1990^{17}$ and with IDAPA 58.01.01, Rules for the Control of Air Pollution in Idaho $^{18}$

- Permits required for compliance with IDAPA 58.01.17, Recycled Water Rules ${ }^{20}$

- Permits required for compliance with IDAPA 37.03.03, Rules for the Construction and Use of Injection Wells in the State of Idaho ${ }^{34}$

- Laboratory-wide permits and records required under the RCRA; Public Law 94-469, Toxic Substances Control Act ${ }^{54}$; 42 USC 11001, Emergency Planning and Community Right-to-Know $A c t^{55}$, and 7 USC 136, Federal Insecticide, Fungicide, and Rodenticide Act ${ }^{56}$

- 42 USC 9601, Comprehensive Environmental Response, Compensation, and Liability Act ${ }^{15}$

- Public Law 104-182, Safe Drinking Water Act ${ }^{41}$.

The INL contractor is also responsible for reporting requirements associated with the following:

- City Order Chapter 1, Section 8, Permits required for compliance with City of Idaho Falls Sewer Ordinance and Municipal Stormwater Discharge Permit ${ }^{32}$.

\subsection{ESER Program Reporting}

The ESER Program prepares the ASER each calendar year, with input from the various organizations performing environmental monitoring on and around the INL Site. The ASER is available electronically, summarizes data from effluent monitoring programs, environmental monitoring activities, and includes a yearly environmental compliance summary for the INL Site. The ASER is prepared as required by DOE Order $231.1 \mathrm{~B}^{53}$.

The ESER Program prepares quarterly reports summarizing off-Site monitoring results and distributes these electronically. A number of other topical reports summarizing trends in data for a particular medium or dealing with other environmental monitoring subjects are produced periodically.

The ESER Program also maintains an environmental public communications and education program. Articles covering environmental monitoring and other ESER Program activities are published in the ESER Program newsletter and in press releases. The ESER Program has established a web site at http://www.gsseser.com/ containing information on the various aspects of the program, all ESER Program data, and recently published reports.

\subsection{USGS Reporting}

All data collected by the USGS INL Project Office are publicly available after review. Most data are published in periodic data reports and used in interpretive reports. The ASER contains an appendix listing the abstracts of USGS publications for the calendar year. The USGS National Water Information System web site is open to the public. This system permits public electronic access and retrieval of USGS water data, including groundwater and water quality data. The web site address is http://waterdata.usgs.gov/id/nwis/.

\subsection{NOAA Reporting}

The NOAA-ARLFRD, Quality Program Plan, NOAA Air Resources Laboratory Field Research Division $^{57}$, addresses the requirements of DOE Order 414D, Quality Assurance ${ }^{8}$, and is consistent with 
ANSI/ANS-3.11-2005, Determining Meteorological Information at Nuclear Facilities ${ }^{58}$. Implementing procedures include regular independent system and performance audits, written procedures and checklists, follow-up actions, and continuous automated and visual data checks to ensure representation and accuracy. The plan and implementing procedures provide the framework to ensure that the INL Meteorological Monitoring Network meets the elements of DOE/EH-0173T ${ }^{4}$ and DOE Order $458.1^{1}$.

Network meteorological data are transmitted every five minutes from each station in NOAA's meteorological network via radio to the central ARLFRD facility in Idaho Falls. The data receive nearly continuous monitoring and quality control screening. Data are recorded on electronic media and stored in a dedicated, computerized archive, with backup media maintained as recommended by DOE/EH-0173T ${ }^{4}$.

Specific climatological data from the IEMP are available in real time to the public electronically at http://www.noaa.inel.gov/. The ARLFRD's data specific to the INL Site are available in near real time electronically at http://niwc.noaa.inel.gov/. Results of past work are summarized in DOE/ID-12118 ${ }^{6}$ and DOE/ID- $12119^{35}$. 


\section{QUALITY ASSURANCE}

An effective quality assurance (QA) program is essential to collect quality data. This section presents QA procedures and practices used as part of the effluent monitoring and environmental monitoring programs. This section does not provide a QA plan for monitoring at the INL Site but rather defines QA requirements applicable to environmental programs. Each monitoring organization incorporates the required components into its QA documentation for environmental monitoring.

The primary policy, requirements, and responsibilities for establishing and maintaining plans and actions that ensure QA in DOE activities are provided in DOE Order 414D ${ }^{8}$, Quality Assurance, 10 CFR 830, Subpart A, Quality Assurance Requirements ${ }^{59}$, and American Society of Mechanical Engineers (ASME) NQA-1-2004, Quality Assurance Requirement for Nuclear Facility Applications ${ }^{60}$. The ASME NQA-1-2004 is the preferred standard for activities at nuclear facilities. Additional QA program requirements found in 40 CFR 61 , Appendix $B^{23}$ must be met for all radiological air emission sources continuously monitored for compliance with 40 CFR 61, Subpart $\mathrm{H}^{5}$.

The EPA policy on QA plans is based on the national consensus standard ANSI/ASQC E4-1994, Specifications and Guidelines for Quality Systems for Environmental Data Collection and Environmental Technology Programs ${ }^{61}$. The EPA approach to data quality centers on the data quality objective process. Data quality objectives are project dependent and are determined on the basis of the data users' needs and the purpose for which data are generated. Quality elements applicable to environmental monitoring and decision-making are specifically addressed in EPA/240/B-01/003, EPA Requirements for Quality Assurance Project Plans (EPA QA/R-5) ${ }^{62}$. These elements are included in the following general categories:

- Project management

- Data generation and acquisition

- Assessment and oversight

- Data validation and usability.

\subsection{QA Requirements}

The QA procedures are designed to ensure sample integrity, precision, and accuracy in the analytical results and to ensure that the environmental data is representative and complete. The following subsections describe how each monitoring organization implements the above QA requirements.

\subsubsection{INL Contractor}

The INL contractor integrates applicable requirements from Manual 13A-Quality and Requirements Management Program Documents ${ }^{63}$, into the implementing monitoring program plans and procedures for non-CERCLA monitoring activities. The program plans address the QA elements as stated in EPA/240/B$01 / 003^{61}$ to ensure that the required standards of data quality are met.

In addition, the INL contractor uses a documented approach for collecting, assessing, and reporting environmental data. Environmental and effluent monitoring are conducted in accordance with PLN-8510 Planning and Management of Environmental Support and Services Monitoring Services Activities ${ }^{36}$, PLN-8515 Data Management Plan for the INL Environmental Support and Services Monitoring Services Program $^{64}$, and PLN-8550 Environmental Support and Services Monitoring Services Surveillance Plan ${ }^{38}$ in order to assure that analytical work for environmental and effluent monitoring supports data quality objectives. 


\subsubsection{ICP Contractor}

All CERCLA monitoring activities at the INL Site are conducted in accordance with DOE/ID-10587, Quality Assurance Project Plan (QAPjP) for Waste Area Groups 1, 2, 3, 4, 5, 6, 7, 10 and Removal Actions $^{65}$. The Quality Assurance Project Plan was written in accordance with EPA/540/G-89/004, Guidance for Conducting Remedial Investigations and Feasibility Studies Under CERCLA, Office of Emergency and Remedial Response ${ }^{66}$. In addition, the ICP contractor uses:

- PLN-720, "Environmental Surveillance Program Plan"28

- PLN-729, "Idaho Cleanup Project Liquid Effluent Monitoring Program Plan"33

- PLN-730, "Idaho Cleanup Project Drinking Water Program Plan”,43

- PLN-1305, "Groundwater Monitoring Program Plan"67

- PLN-1373, "Groundwater Monitoring Plan for the Waste Calcining Facility and for the CPP601/627/640 Facility"68.

\subsubsection{AMWTP}

AMWTP maintains a QA program in accordance with 40 CFR 61, Appendix B ${ }^{23}$, as required of all radiological air emission sources continuously monitored for compliance with 40 CFR 61, Subpart $\mathrm{H}^{5}$. The QA requirements are documented in AMWTP-PD-EC\&P-02, Quality Assurance Project Plan for the WMF 676 NESHAPs Stack Monitoring System ${ }^{69}$.

\subsubsection{ESER Program}

The ESER Program maintains a QA program consistent with the requirements of 10 CFR $830^{60}$ and DOE Order $414 \mathrm{D}^{8}$ that is implemented through the ESER Quality Assurance Implementation Plan $(O I P)^{70}$. Additional QA requirements for monitoring activities are provided in the ESER Offsite Environmental Surveillance Program Quality Assurance Project Plan ${ }^{71}$. Analytical laboratories used by the ESER Program maintain their own QA programs consistent with DOE requirements.

\subsubsection{NOAA}

A QA plan ${ }^{55}$ addresses the requirements of DOE Order $414 \mathrm{D}^{8}$, and is consistent with ASME. Implementing procedures include regular independent system and performance audits, written procedures and checklists, follow-up actions, and continuous automated and visual data checks to ensure representativeness and accuracy. The plan and implementing procedures provide the framework to ensure that the INL Meteorological Monitoring Network meets the elements of DOE/EH-0173T ${ }^{4}$ and DOE Order $458.1^{1}$.

All the meteorological sensors in the ARLFRD tower network are inspected, serviced, and calibrated semiannually as recommended by American Nuclear Society guidelines found in ANSI/ANS-3.11-2005 ${ }^{58}$. Unscheduled service is also promptly performed whenever a sensor malfunctions.

\subsection{Sample and Analysis Management Activities}

Sample and analysis management activities are performed separately by the various monitoring organizations. Functions performed by each of these monitoring organizations include:

- Developing a Sample and Analysis Plan or equivalent

- Coordinating sampling

- Obtaining analytical laboratory services

- Processing analytical laboratory data packages 
- Managing sample and analytical data

- Validating analytical data (where applicable)

- Coordinating sample disposition.

Subcontract laboratories used by the INL and ICP contractors are audited by the DOE Consolidated Audit Program. This program uses trained and certified personnel to perform in-depth audits of subcontract laboratories to review:

- Personnel training and qualification

- Detailed analytical procedures

- Calibration of instrumentation

- Participation in an inter-comparison program

- Use of blind controls

- Analysis of calibration standards.

Audit results are maintained by the DOE Consolidated Audit Program. Laboratories are required to provide corrective action plans for audit findings. 


\section{RADIOLOGICAL DOSE EVALUATION}

Potential radiological doses to the public from INL Site operations are evaluated to determine compliance with pertinent regulations and limits. Two different computer codes are used to estimate doses. The EDE for a maximally exposed individual (MEI) to INL Site airborne releases of radionuclides is calculated annually using the methods prescribed by Subpart H of 40 CFR $61^{5}$ and documented in an annual NESHAP report for radionuclides ${ }^{25}$. The annual dose to the public for the MEI and the collective $80-\mathrm{km}(50-\mathrm{mi})$ population and the biota dose are estimated annually and documented in DOE/ID-12082, Idaho National Laboratory Site Environmental Report ${ }^{75}$.

\subsection{Maximum Individual Dose-Airborne Emissions Pathway}

The EDE to an individual member of the public is calculated from airborne emission sources across the INL Site to demonstrate compliance with Subpart H of 40 CFR $61^{5}$ and DOE Order $458.1^{1}$. Subpart H requires that emissions of radionuclides to the ambient air from DOE facilities shall not exceed those amounts that would cause any member of the public to receive an EDE of 10 millirem per year. The purpose of DOE Order $458.1^{1}$ is to implement sound stewardship practices that protect the air, water, land, and other natural and cultural resources impacted by DOE operations, and by which DOE cost effectively meets or exceeds compliance with applicable environmental, public health, and resource protection laws, regulations, and DOE requirements. DOE Order $458.1^{1}$ states it is also a DOE objective that potential exposures to members of the public be as far below the limits as is reasonable achievable.

Because individual radiological impacts to the public surrounding the INL Site remain too small to be measured by available monitoring techniques, the dose to the public from INL Site operations is calculated using the reported amounts of radionuclides released from INL Site facilities and EPAapproved air dispersion codes. Compliance to Subpart H of 40 CFR $61^{5}$ is demonstrated primarily through the use of the CAP-88 computer code.

\subsubsection{Dose Evaluation Using CAP-88 Computer Code}

Use of the CAP- 88 computer code is required by the EPA to demonstrate compliance with the Clean Air Act Amendments of $1990^{17}$. Using the CAP-88 code and information on the reported amounts of radionuclides released from INL Site facilities, the EDE to the MEI is estimated. CAP- 88 uses dose and risk tables developed by the EPA. It does not include shielding by housing materials, but does include a factor to allow for shielding by surface soil contours from radioactivity on the ground surface. The ARLFRD performs annual meteorological and dispersion assessments as part of the environmental compliance at the Site. Yearly wind statistics are generated for many of the towers in the meteorological network; these are used to run the CAP-88 plume dispersion code required for NESHAP 5 compliance. CAP-88 makes its calculations based on the joint frequency of wind conditions from a single wind station located near a facility (or emission source) in a straight line from that source and ignores recirculation.

\subsubsection{Dose Evaluation Using MDIFF Dispersion Model}

The ARLFRD developed and maintains a puff transportation and dispersion model called MDIFF to estimate radiological pollutant emissions from the INL Site. The mesoscale diffusion (MDIFF) calculations of total integrated concentrations are used to evaluate the dose to members of the public to show compliance with DOE Order 458.1 ${ }^{1}$ (NOAA-TM-OAR-ARL-238, PB-2001-014789) ${ }^{72}$.

This method offers a more realistic dose estimate for the Site than that from the CAP- 88 code. The dispersion algorithms within the code, which are derived in part from field data collected at the Site and the puff transport, are driven by the wind data from the ARLFRD tower network. The MDIFF is used only for calculating population dose. Unlike CAP-88, MDIFF can account for spatial and temporal wind variations associated with the complex topography near the Site. 
The ARLFRD has also developed a program called INLViz to display data in near real time from the tower network and the vertical profilers. The program contains a user interface to the MDIFF puff dispersion code. INLViz has been installed at about 50 locations in and around the Site. It is widely used to support Site operations, and is a major part of ARLFRD's support to the INL Site Emergency Operations Center.

\subsection{0-Kilometer (50-Mile) Population Dose}

An estimate of the collective EDE, or population dose, from inhalation, submersion, ingestion, and deposition resulting from airborne releases of radionuclides from the INL Site is determined from the MDIFF evaluations and information on the population within $80 \mathrm{~km}(50 \mathrm{mi})$ of an INL Site facility. Results of the MDIFF population dose evaluations are used to show compliance with DOE Order 458.1 ${ }^{1}$. The population dose is calculated from the average dispersion coefficient for the county census division, the population in each census division within that county, and the normalized dose received at the location of the MEI from the MDIFF evaluation. This gives an approximation of the dose received by the entire population in a given county division. Total population dose is the sum of the population dose for the various county divisions. The calculation overestimates dose because radioactive decay and deposition of the isotopes is not calculated during transport over distances greater than that to the MEI. Population estimates are reviewed and updated annually, as necessary.

\subsection{Biotic Dose}

Maximum radionuclide concentrations in waterfowl and game animals collected from the INL Site are used to estimate a potential dose from ingestion. Estimates of the potential dose an individual may receive from occasionally ingesting meat from game animals take into account that waterfowl may reside briefly at the various waste disposal ponds on the Site and those game birds and other game animals may reside on or migrate across the Site. The potential dose estimate is based on the highest concentrations of radionuclides in waterfowl or game animals sampled from the Site.

A graded approach is used to evaluate the potential dose to aquatic and terrestrial biota from contaminated soil and water according to DOE-STD-1153-2002, A Graded Approach for Evaluating Radiation Doses to Aquatic and Terrestrial Biota ${ }^{73}$. The graded approach evaluates the impacts of a given set of radionuclides on aquatic and terrestrial ecosystems by comparing available concentration data in soils and water with biota concentration guides. Details and justifications for applying the graded approach at the INL Site can be found in NW-ID-2003-062, Biota Dose Assessment Guidance for the INEEL $L^{74}$. 


\section{REFERENCES}

1. DOE Order 458.1, "Radiation Protection of the Public and the Environment" U.S. Department of Energy, current version.

2. DOE Order 436.1, "Departmental Sustainability," U.S. Department of Energy, current version.

3. DOE Order 435.1, "Radioactive Waste Management," U.S. Department of Energy, current version.

4. DOE/EH-0173T, "Environmental Regulatory Guide for Radiological Effluent Monitoring and Environmental Surveillance,” U.S. Department of Energy, current version.

5. 40 CFR 61, Subpart H, "National Emission Standards for Emissions of Radionuclides other than Radon from Department of Nuclear Facilities," Environmental Protection Agency, Code of Federal Regulations, current version.

6. K. L. Clawson, G. E. Start, and N. R. Ricks, Climatography of the Idaho National Engineering Laboratory, $2^{\text {nd }}$ Edition, DOE/ID-12118, December 1989.

7. Executive Order 12344, "Naval Nuclear Propulsion Program," appears at 47 FR 4979, 3 CFR, 1982 Comp., p. 128.

8. DOE Order 414D, "Quality Assurance," U.S. Department of Energy, current version.

9. Bechtel Marine Propulsion Corporation, Naval Reactors Facility Environmental Monitoring Program, Naval Reactors Facility, current version.

10. ANSI/ISO 14001, "Environmental Management System," International Organization for Standardization, current version.

11. DOE/ID-10997, "Idaho National Laboratory Cultural Resource Management Plan," Department of Energy Idaho Operations Office, current version.

12. W. Singlevich, et al, "Natural Radioactive Material at the Arco Reactor Test Site," Report No. HW-21221, Ecological and Radiological Studies of the Arco Reactor Test Site, Richland General Electric Nucleonics Division, Hanford Works, pp. 1-49.

13. EGG-1183-1681, An Aerial Radiological Survey of the Idaho National Engineering Laboratory, EG\&G RECO.

14. Federal Facility Agreement and Consent Order for the Idaho National Engineering Laboratory, U.S. Department of Energy Idaho Operations Office; U.S. Environmental Protection Agency, Region 10; State of Idaho, Department of Health and Welfare.

15. $\quad 42$ U.S.C. $§ 9601$ et seq., "Comprehensive Environmental Response, Compensation, and Liability Act (CERCLA)," Environmental Protection Agency (Superfund), U.S. Code, current version.

16. Environmental Oversight and Monitoring Agreement between U.S. Department of Energy and the State of Idaho, current version.

17. Public Law 91-604, "Clean Air Act Amendments of 1990," U.S. Environmental Protection Agency, current version.

18. IDAPA 58.01.01, "Rules for the Control of Air Pollution in Idaho," Idaho Department of Environmental Quality, Idaho Administrative Code, current version. 
19. IDAPA 58.01.16, "Wastewater Rules,” Idaho Department of Environmental Quality, Idaho Administrative Code, current version.

20. IDAPA 58.01.17, "Recycled Water Rules," Idaho Department of Environmental Quality, Idaho Administrative Code, current version.

21. IDAPA 58.01.11, "Ground Water Quality Rule, "Idaho Department of Environmental Quality, Idaho Administrative Code, current version.

22. DOE-ID, "Agreement-In-Principle Between the Shoshone-Bannock Tribes and The United States Department of Energy," current version.

23. 40 CFR 61, Appendix B, "Method 114," Environmental Protection Agency, Code of Federal Regulations, current version.

24. ANSI N13.1-1999, "Sampling and Monitoring Releases of Airborne Radioactive Substances from the Stacks and Ducts of Nuclear Facilities," American National Standards Institute, current version.

25. DOE/ID-10890, "National Emission Standards for Hazardous Air Pollutants- INL Report for Radionuclides," U.S. Department of Energy Idaho Operations Office, current version.

26. $\quad 40$ CFR 61.93 "Emission Monitoring and Test Procedures," Environmental Protection Agency, Code of Federal Regulations, current version.

27. Wilson, Wenona, Environmental Protection Agency, letter to Mr. Tim J. Safford, U.S. Department of Energy Idaho Operations Office, "Idaho National Laboratory Request for Alternative Air Monitoring Method for Accelerated Retrieval Project WMF-1617," CCN 315952.

28. PLN-720, "Environmental Surveillance Program Plan,” Idaho Cleanup Project, Environmental Monitoring Compliance Monitoring Handbook, current version.

29. AMWTP-MP-EC\&P-7.5, “Advanced Mixed Waste Treatment Plant National Emissions Standards for Hazardous Air Pollutants Emissions of Radionuclides," current version.

30. PLN-8540, "Idaho National Laboratory Liquid Effluent Monitoring Plan," Idaho National Laboratory, Laboratory-wide Manual 8 - Environmental Protection and Compliance, current version.

31. PLN-932, "Management Plan and Implementation of Best Available Technology per DOE Order 5400.5 for Disposal of Wastewater," Idaho Cleanup Project, Environmental Monitoring Compliance Monitoring Handbook, current version.

32. City Order Chapter 1, Section 8, "City of Idaho Falls Sewer Ordinance," 1994.

33. PLN-729, “Idaho Cleanup Project Liquid Effluent Monitoring Program Plan,” Idaho Cleanup Project, Environmental Monitoring Compliance Monitoring Handbook, current version.

34. IDAPA 37.03.03, "Rules for Construction and Use of Injection Wells," Idaho Administrative Code, current version.

35. DOE/ID-12119, "Idaho National Engineering Laboratory Historical Dose Evaluation," U.S. Department of Energy Idaho Operations Office, April 5, 2006.

36. PLN-8510, "Planning and Management of Environmental Monitoring Activities," Idaho National Laboratory, Laboratory-wide Manual 8 - Environmental Protection and Compliance, current version. 
37. PLN-8550, Environmental Support and Services Monitoring Services Surveillance Plan, Idaho National Laboratory, current version.

38. LI-351, Sampling Atmospheric Tritium, Idaho National Laboratory, current version.

39. Environmental Science, Education and Research Program (ESER), Environmental Program Procedures, current versions, Gonzales-Stoller Surveillance, LLC.

40. IDAPA 58.01.08, "Idaho Rules for Public Drinking Water Systems, Idaho Department of Environmental Quality, Idaho Administrative Code, current version.

41. Public Law 104-182, "Safe Drinking Water Act," U.S. Environmental Protection Agency, current version.

42. PLN-8530, "Idaho National Laboratory Drinking Water Program Plan," Idaho National Laboratory, Laboratory-wide Manual 8 - Environmental Protection and Compliance, current version.

43. PLN-730, "Idaho Cleanup Project Drinking Water Program Plan," Idaho Cleanup Project, Environmental Monitoring Compliance Monitoring Handbook, current version.

44. DOE/ID-11034, "Idaho National Laboratory Groundwater Monitoring and Contingency Plan," U.S. Department of Energy Idaho Operations Office, current version.

45. Leroy L. Knobel, Betty J. Tucker and Joseph P. Rousseau, Field Methods and Quality Assurance Plan for Quality-of-Water Activities, U.S. Geological Survey, Idaho National Laboratory, DOE/ID22206, 2008.

46. 33 USC $§ 1251$, "Federal Clean Water Act," U.S. Code, current version.

47. R. L. VanHorn, C. Fordham, and T. J. Haney, Long-Term Ecological Monitoring Plan for the Idaho National Engineering and Environmental Laboratory, INEEL/EXT-02-01191, Revision 1, January 2004.

48. EXT-95-00496, Record of Decision Declaration for Central Facilities Area Landfills, I, II, and III (Operable Unit 4-12), and No Action Site, (Operable Unit 4-03), U.S. Department of Energy Idaho Operations Office, September 1995.

49. INEL-95/0585, Field Sampling Plan (FSP) for Post-Record of Decision (ROD) Monitoring for the Central Facilities Area (CFA) Landfills I, II, and III Under Operable Unit (OU) 4-12, Idaho National Laboratory, current version.

50. PLN-114, 2005, "INL Emergency Plan/RCRA Contingency Plan,” Idaho National Laboratory, Manual 16A-Emergency Preparedness, current version.

51. AMWTP-5232-MP-EC\&P-7.10, "Spill Response Procedure,” current version.

52. AMWTP-MP-EP\&C-12.1, “AMWTP Emergency Plan/RCRA Contingency Plan,” current version.

53. DOE Order 231.1B, Chg. 1, "Environment, Safety and Health Reporting," U.S. Department of Energy, current version.

54. Public Law 94-469, “Toxic Substances Control Act (TSCA),” U.S. Environmental Protection Agency, current version. 
55. 42 U.S.C. 11001 et seq., "Emergency Planning and Community Right-to-Know Act of 1986," Environmental Protection Agency, U.S. Code, current version.

56. 7 U.S.C. $§ 136$ et seq., "Federal Insecticide, Fungicide, and Rodenticide Act," Environmental Protection Agency, U.S. Code, current version.

57. NOAA-ARLFRD, 1993, Quality Program Plan, NOAA Air Resources Laboratory Field Research Division, November 1993.

58. ANSI/ANS-3.11-2005, "Determining Meteorological Information at Nuclear Facilities," American National Standards Institute/American Nuclear Society, 2005.

59. 10 CFR 830, Subpart A, “Quality Assurance Requirements," Environmental Protection Agency, Code of Federal Regulations, current version.

60. ASME NQA-1-2004 "Quality Assurance Requirements for Nuclear Facility Applications," American Society of Mechanical Engineers, current version.

61. ANSI/ASQC E4-1994, "Specifications and Guidelines for Quality Systems for Environmental Data Collection and Technology Programs" (e-standard), U.S. Environmental Protection Agency, current version.

62. EPA/240/B-01/003, "EPA Requirements for Quality Assurance Project Plans (EPA QA/R-5)," Environmental Protection Agency, current version.

63. Manual 13A-Quality and Requirements Management Program Documents, Idaho National Laboratory, current version.

64. PLN-8515 Data Management Plan for the INL Environmental Support and Services Monitoring Services Program, Idaho National Laboratory, current version.

65. DOE/ID-10587, “Quality Assurance Project Plan for Waste Area Groups 1, 2, 3, 4, 5, 6, 7, 10 and Removal Actions," U.S. Department of Energy Idaho Operations Office, current version.

66. EPA/540/G-89/004, Guidance for Conducting Remedial Investigations and Feasibility Studies Under CERCLA, Office of Emergency and Remedial Response, U.S. Environmental Protection Agency, current version.

67. PLN-1305, "Groundwater Monitoring Program Plan," Idaho Cleanup Project, Environmental Monitoring Compliance Monitoring Handbook, current version.

68. PLN-1373, "Groundwater Monitoring Plan for the Waste Calcining Facility and for the CPP601/627/640 Facility," Idaho Cleanup Project, Environmental Monitoring Compliance Monitoring Handbook, current version.

69. AMWTP-PD-EC\&P-02, “Quality Assurance Project Plan for the WMF-676 NESHAPs Stack Monitoring System," current version.

70. ESER (S. M. Stoller Corporation), “Quality Assurance Implementation Plan,” current version.

71. ESER (S. M. Stoller Corporation), "Offsite Environmental Surveillance Program Quality Assurance Project Plan," current version.

72. J. F. Sagendorf, R. G. Carter, and K. L. Clawson, MDIFF Transport and Diffusion Model, NOAA Air Resources Laboratory, NOAA Technical Memorandum, NOAA-TM-OAR-ARL-238, PB-2001-014789, February 2001. 
73. DOE-STD-1153-2002, "A Graded Approach for Evaluating Radiation Doses to Aquatic and Terrestrial Biota," U.S. Department of Energy, current version.

74. Morris, R. C, Biota Dose Assessment Guidance for the INEEL, NW-ID-2003-062, North Wind, Inc. for Environmental Surveillance, Education and Research Program, September 2003.

75. DOE/ID-12082, "Idaho National Laboratory Site Environmental Report,” U.S. Department of Energy Idaho Operations Office, current version. 
Appendix A Monitoring Locations

A-A-1 
The tables in this appendix contain individual sampling locations for media discussed in this environmental monitoring plan and that are included in the maps and figures in the plan. The following definitions apply to the headings found in the following tables:

- EMP_REF_ID; A unique integer assigned to each sample point. This ID number is specific to each sample location identified on the maps in the Environmental Monitoring Plan.

- LOC_NAME; The common name assigned to a sample (e.g. 400.3, SDA 2.3). The LOC_NAME is NOT unique and more than one sample location may have the same name.

- LOCATION DESCRIPTION; A description of geographical location assigned to the GRL_ID (i.e. 252; Rexburg - Behind Madison Middle School). 
Table A-1. Airborne Effluent Monitoring Locations.

\begin{tabular}{|l|l|l|l|}
\hline EMP_REF_ID & \multicolumn{1}{|c|}{ LOC_NAME } & CON_ID & \multicolumn{1}{c|}{ LOCATION DESCRIPTION } \\
\hline 32 & EBR-II/FCF Main Stack (ANL-764) & BEA & MFC - Inside facility fence \\
\hline 33 & HFEF Stack (ANL-785) & BEA & MFC - Inside facility fence \\
\hline 36 & INTEC Main Stack (CPP-708) & CWI & INTEC - Inside facility fence \\
\hline 37 & INTEC New Waste Calciner (CPP-659) & CWI & INTEC - Inside facility fence \\
\hline 38 & Advanced Retrieval Project & CWI & RWMC/SDA - Inside facility fence \\
\hline 35 & Glovebox Extract (WMF-676-003) & ITG & RWMC - TSA/AMWTP area \\
\hline
\end{tabular}


Table A-2. Soil Gas and Soil Moisture Surveillance Locations.

\begin{tabular}{|c|c|c|c|}
\hline EMP_REF_ID & LOC_NAME & CON_ID & LOCATION DESCRIPTION \\
\hline 538 & LF3-East & BEA & CFA Landfill \\
\hline 539 & LF3-West & BEA & CFA Landfill \\
\hline 540 & LF2-North & BEA & CFA Landfill \\
\hline 541 & LF2-South & BEA & CFA Landfill \\
\hline 542 & CFA-GAS-V-004 & BEA & CFA Landfill \\
\hline 543 & CFA-GAS-V-005 & BEA & CFA Landfill \\
\hline 544 & CFA-GAS-V-006 & BEA & CFA Landfill \\
\hline 545 & CFA-GAS-V-007 & BEA & CFA Landfill \\
\hline 546 & CFA-GAS-V-008 & BEA & CFA Landfill \\
\hline 563 & LF2-03 & BEA & CFA Landfill \\
\hline 564 & LF2-04 & BEA & CFA Landfill \\
\hline 565 & LF2-07 & BEA & CFA Landfill \\
\hline 566 & LF3-03 & BEA & CFA Landfill \\
\hline 567 & LF3-05 & BEA & CFA Landfill \\
\hline 547 & TEM2-A & CWI & RWMC facility area \\
\hline 548 & TEM3-A & CWI & RWMC facility area \\
\hline 549 & 9302 & CWI & RWMC facility area \\
\hline 550 & D-02 & CWI & RWMC facility area \\
\hline 551 & 89-02D & CWI & RWMC facility area \\
\hline 552 & 9301 & CWI & RWMC facility area \\
\hline 553 & WWW1 & CWI & RWMC facility area \\
\hline 554 & USGS-118 & CWI & RWMC facility area \\
\hline 555 & $78-4$ & CWI & RWMC facility area \\
\hline 556 & $77-1$ & CWI & RWMC facility area \\
\hline 557 & M10S & CWI & RWMC facility area \\
\hline 558 & M1SA & CWI & RWMC facility area \\
\hline 559 & 88-01D & CWI & RWMC facility area \\
\hline 560 & M3S & CWI & RWMC facility area \\
\hline 561 & M6S & CWI & RWMC facility area \\
\hline 562 & M7S & CWI & RWMC facility area \\
\hline 568 & VVE-7 & CWI & RWMC facility area \\
\hline 569 & SOUTH-MON-A-010 & CWI & RWMC facility area \\
\hline
\end{tabular}


Table A-2. (continued).

\begin{tabular}{|c|c|c|c|}
\hline EMP_REF_ID & LOC_NAME & CON_ID & LOCATION DESCRIPTION \\
\hline 570 & SOUTH-MON-A-009 & CWI & RWMC facility area \\
\hline 571 & VVE-6 & CWI & RWMC facility area \\
\hline 572 & SOUTH-1898 & CWI & RWMC facility area \\
\hline 573 & VVE-4 & CWI & RWMC facility area \\
\hline 574 & SOUTH-1835 & CWI & RWMC facility area \\
\hline 575 & VVE-10 & CWI & RWMC facility area \\
\hline 576 & RWMC-GAS-V-081 & CWI & RWMC facility area \\
\hline 577 & RWMC-VVE-V-204 & CWI & RWMC facility area \\
\hline 578 & RWMC-VVE-V-205 & CWI & RWMC facility area \\
\hline 579 & RWMC-1816 & CWI & RWMC facility area \\
\hline 580 & RWMC-GAS-V-074 & CWI & RWMC facility area \\
\hline 581 & RWMC-1819 & CWI & RWMC facility area \\
\hline 582 & RWMC-GAS-V-075 & CWI & RWMC facility area \\
\hline 583 & RWMC-VVE-V-071 & CWI & RWMC facility area \\
\hline 584 & RWMC-GAS-V-076 & CWI & RWMC facility area \\
\hline 585 & RWMC-GAS-V-077 & CWI & RWMC facility area \\
\hline 586 & RWMC-GAS-V-078 & CWI & RWMC facility area \\
\hline 587 & RWMC-VVE-V-067 & CWI & RWMC facility area \\
\hline 588 & RWMC-GAS-V-079 & CWI & RWMC facility area \\
\hline 589 & RWMC-1810 & CWI & RWMC facility area \\
\hline 590 & RWMC-GAS-V-080 & CWI & RWMC facility area \\
\hline 591 & RWMC-MON-A-162 & CWI & RWMC facility area \\
\hline 592 & VVE-1 & CWI & RWMC facility area \\
\hline 593 & RWMC-VVE-V-163 & CWI & RWMC facility area \\
\hline 594 & VVE-3 & CWI & RWMC facility area \\
\hline 595 & RWMC-1809 & CWI & RWMC facility area \\
\hline 596 & RWMC-1812 & CWI & RWMC facility area \\
\hline 597 & RWMC-1815 & CWI & RWMC facility area \\
\hline 598 & RWMC-1818 & CWI & RWMC facility area \\
\hline 599 & RWMC-1821 & CWI & RWMC facility area \\
\hline 600 & RWMC-GAS-V-072 & CWI & RWMC facility area \\
\hline 601 & RWMC-1822 & CWI & RWMC facility area \\
\hline
\end{tabular}


Table A-2. (continued).

\begin{tabular}{|l|l|l|l|}
\hline EMP_REF_ID & \multicolumn{1}{|c|}{ LOC_NAME } & CON_ID & \multicolumn{1}{c|}{ LOCATION DESCRIPTION } \\
\hline 602 & RWMC-VVE-V-068 & CWI & RWMC facility area \\
\hline 603 & RWMC-GAS-V-073 & CWI & RWMC facility area \\
\hline 604 & RWMC-1813 & CWI & RWMC facility area \\
\hline 605 & RWMC-VVE-V-069 & CWI & RWMC facility area \\
\hline 606 & RWMC-1817 & CWI & RWMC facility area \\
\hline 607 & RWMC-1820 & CWI & RWMC facility area \\
\hline 608 & RWMC-1808 & CWI & RWMC facility area \\
\hline 609 & RWMC-1814 & CWI & RWMC facility area \\
\hline
\end{tabular}


Table A-3. Atmospheric Moisture Surveillance Locations.

\begin{tabular}{|l|l|l|l|}
\hline EMP_REF_ID & \multicolumn{1}{|c|}{ LOC_NAME } & CON_ID & \multicolumn{1}{|c|}{ LOCATION DESCRIPTION } \\
\hline 667 & Tritium Air Monitor - IF & BEA & $\begin{array}{l}\text { Idaho Falls - Located at the INL Research } \\
\text { Center (IRC) facility, southeast corner of } \\
\text { Building IF-627 }\end{array}$ \\
\hline 677 & Tritium Air Monitor - EFS & BEA & $\begin{array}{l}\text { Experimental Field Station - West of facility } \\
\text { fence }\end{array}$ \\
\hline 678 & Tritium Air Monitor - Craters & BEA & Craters of the Moon \\
\hline 679 & Tritium Air Monitor - VAN B & BEA & $\begin{array}{l}\text { Van Buren Blvd just north of U.S. Highway } \\
20 / 26\end{array}$ \\
\hline 95 & Blackfoot & GSS & Blackfoot \\
\hline 260 & Idaho Falls & GSS & $\begin{array}{l}\text { Idaho Falls - North of TSA/TSB on east side } \\
\text { of Foot Rd. }\end{array}$ \\
\hline 261 & Atomic City & GSS & Atomic City at NOAA tower \\
\hline 663 & Sugar City & GSS & Sugar City \\
\hline
\end{tabular}


Table A-4. Liquid Effluent Monitoring Locations.

\begin{tabular}{|c|c|c|c|}
\hline EMP_REF_ID & LOC_NAME & CON_ID & LOCATION DESCRIPTION \\
\hline 214 & MFC Industrial Waste Pond & BEA & MFC - Industrial Waste Pond \\
\hline 215 & $\begin{array}{l}\text { CFA Sewage Treatment } \\
\text { Facility }\end{array}$ & BEA & CFA - Southeast sewage treatment lagoon \\
\hline 217 & IRC & BEA & $\begin{array}{l}\text { Idaho Falls IRC Facility - Point located in } \\
\text { the center of the N. Boulevard at main IRC } \\
\text { entrance }\end{array}$ \\
\hline 220 & TRA Cold Waste Pond & BEA & ATR Complex - Building TRA-764 \\
\hline 221 & B21-608 & BEA & CFA Rifle Range Building B21-608 \\
\hline 223 & MFC Ditch C & BEA & $\begin{array}{l}\text { West of MFC-TR- } 62 \text { inside the facility } \\
\text { fence }\end{array}$ \\
\hline 224 & $\begin{array}{l}\text { MFC Industrial Waste } \\
\text { Ditch/Pipeline }\end{array}$ & BEA & $\begin{array}{l}\text { West of MFC-793C inside the facility } \\
\text { fence }\end{array}$ \\
\hline 216 & СРP-797 & CWI & $\begin{array}{l}\text { INTEC - Building CPP-797 inside facility } \\
\text { fence }\end{array}$ \\
\hline 218 & СРР-769 & CWI & $\begin{array}{l}\text { INTEC - Sewage treatment lagoon } \\
\text { Building CPP-769 }\end{array}$ \\
\hline 219 & CPP-773 & CWI & $\begin{array}{l}\text { INTEC - Sewage treatment lagoon } \\
\text { Building CPP-773 }\end{array}$ \\
\hline
\end{tabular}


Table A-5. Stormwater Effluent Monitoring Locations.

\begin{tabular}{|l|l|l|l|}
\hline EMP_REF_ID & \multicolumn{1}{|c|}{ LOC_NAME } & CON_ID & \multicolumn{1}{c|}{ LOCATION DESCRIPTION } \\
\hline 610 & CFA-MP-3 & BEA & CFA - East of CFA-609 \\
\hline 611 & TAN DISP 01 & BEA & TAN/TSF - South facility fence \\
\hline 612 & TAN DISP 02 & BEA & TAN/TSF - Inside facility fence \\
\hline 613 & TAN DISP 03 & BEA & TAN/SMC - Inside facility fence east of SMC \\
\hline 614 & SPERT DISP 1 & BEA & CITRC - South of PBF Support Area \\
\hline 615 & SPERT DISP 2 & BEA & $\begin{array}{l}\text { CITRC - South of facility near the intersection of } \\
\text { Jefferson Blvd. and Wilson Blvd. }\end{array}$ \\
\hline 616 & SPERT DISP 3 & BEA & CITRC - South of facility and west of Jefferson Blvd. \\
\hline
\end{tabular}


Table A-6. Ambient Air Surveillance Locations.

\begin{tabular}{|c|c|c|c|}
\hline EMP REF ID & LOC_NAME & CON_ID & LOCATION DESCRIPTION \\
\hline 57 & $\mathrm{SMC}$ & BEA & $\begin{array}{l}\text { TAN/SMC - North of SMC facility fence at } \\
\text { NOAA tower }\end{array}$ \\
\hline 58 & Gate4 & BEA & $\begin{array}{l}\text { Sand Dunes NOAA tower - South of } \\
\text { Lincoln Blvd. guard gate \#4 }\end{array}$ \\
\hline 59 & ANL-W & BEA & MFC - West side of MFC facility fence \\
\hline 61 & $\mathrm{PBF}$ & BEA & CITRC at PBF Support Area \\
\hline 63 & RTC & BEA & ATR Complex - NE corner of facility fence \\
\hline 64 & TRA & BEA & $\begin{array}{l}\text { ATR Complex - Parking lot along facility } \\
\text { fence }\end{array}$ \\
\hline 65 & intec & BEA & INTEC - North of facility \\
\hline 66 & $\mathrm{CPP}$ & BEA & $\begin{array}{l}\text { INTEC - Along the west side of the facility } \\
\text { fence south of Cleveland Blvd. }\end{array}$ \\
\hline 68 & Rest Area & BEA & $\begin{array}{l}\text { Big Lost River Rest Area on U.S. Highway } \\
20 / 26\end{array}$ \\
\hline 69 & CFA & BEA & CFA - North of Building CF-690 \\
\hline 634 & IF & BEA & $\begin{array}{l}\text { Idaho Falls - North of TSA/TSB on east } \\
\text { side of Foote Dr. }\end{array}$ \\
\hline 639 & Craters & BEA & Craters of the Moon \\
\hline 641 & Blackfoot & BEA & Blackfoot - Mountain View Middle School \\
\hline 643 & Van Buren & BEA & $\begin{array}{l}\text { Van Buren Blvd just north of U.S. } \\
\text { Highway } 20 / 26\end{array}$ \\
\hline 644 & EFS & BEA & $\begin{array}{l}\text { Experimental Field Station - West of } \\
\text { facility fence }\end{array}$ \\
\hline 645 & EBR-I & BEA & $\begin{array}{l}\text { EBR-I - Inside facility fence south of } \\
\text { EBR-602 }\end{array}$ \\
\hline 646 & RWMC & BEA & $\begin{array}{l}\text { RWMC - Northeast of Pit } 9 \text { just outside of } \\
\text { facility fence }\end{array}$ \\
\hline 655 & NRF & BEA & $\begin{array}{l}\text { NRF - NW of new communication tower } \\
\text { south of the main parking lot }\end{array}$ \\
\hline 656 & ARA & BEA & $\begin{array}{l}\text { North of ARA I \& II facility area on } \\
\text { perimeter road }\end{array}$ \\
\hline 666 & $2 \mathrm{INCH}$ AIR - IRC & BEA & $\begin{array}{l}\text { Idaho Falls - Located at the INL Research } \\
\text { Center (IRC) facility, east of Building } \\
\text { IF-605 }\end{array}$ \\
\hline 67 & INT 100.3 & CWI & INTEC/ICDF - Just east of TR-55 \\
\hline 70 & EBF 1.3 & CWI & $\begin{array}{l}\text { EBR-I - Inside facility fence south of } \\
\text { EBR-602 }\end{array}$ \\
\hline
\end{tabular}


Table A-6. (continued).

\begin{tabular}{|c|c|c|c|}
\hline EMP REF ID & LOC_NAME & CON_ID & LOCATION DESCRIPTION \\
\hline 71 & SDA 2.3 & CWI & $\begin{array}{l}\text { RWMC - Northeast of Pit } 9 \text { just outside of } \\
\text { facility fence }\end{array}$ \\
\hline 72 & SDA 1.3 & CWI & RWMC - East side of the SDA \\
\hline 73 & SDA 11.3 & CWI & RWMC - Southeast side of the SDA \\
\hline 74 & SDA 9.3 & CWI & RWMC - Southwest side of the SDA \\
\hline 75 & SDA 6.3 & $\mathrm{CWI}$ & RWMC - Northwest side of the SDA \\
\hline 76 & SDA 4.2 & CWI & RWMC - Northeast side of the SDA \\
\hline 77 & SDA 4.3 & CWI & RWMC - Northeast side of the SDA \\
\hline 78 & EBP 1.3 & CWI & $\begin{array}{l}\text { Van Buren Blvd. } 0.7 \text { miles north of EBR-I } \\
\text { near cell phone tower }\end{array}$ \\
\hline 79 & EBP 1.2 & CWI & $\begin{array}{l}\text { Van Buren Blvd. } 0.7 \text { miles north of EBR-I } \\
\text { near cell phone tower }\end{array}$ \\
\hline 635 & Howe 400.4 & CWI & Howe \\
\hline 636 & ARPBKG.1 & CWI & Howe \\
\hline 39 & Idaho Falls & GSS & $\begin{array}{l}\text { Idaho Falls - North of TSA/TSB on east } \\
\text { side of Foote Dr. }\end{array}$ \\
\hline 40 & DuBois & GSS & DuBois \\
\hline 42 & Mud Lake & GSS & $\begin{array}{l}\text { Mud Lake - South of State HWY } 33 \text { on N } \\
1100 \text { East }\end{array}$ \\
\hline 44 & FAA Tower & GSS & $\begin{array}{l}\text { FAA Tower - U.S. HWY } 20 \text { west of mile } \\
\text { marker } 282\end{array}$ \\
\hline 45 & Main Gate & GSS & Main Guard Gate \\
\hline 46 & Van Buren & GSS & $\begin{array}{l}\text { Van Buren Blvd just north of U.S. } \\
\text { Highway } 20 / 26\end{array}$ \\
\hline 47 & Craters of the Moon & GSS & Craters of the Moon \\
\hline 48 & $\begin{array}{l}\text { Mountain View Middle } \\
\text { School }\end{array}$ & GSS & Blackfoot - Mountain View Middle School \\
\hline 49 & Jackson Hole & GSS & Jackson Hole \\
\hline 50 & Monteview & GSS & $\begin{array}{l}\text { Monteview - Near intersection of E } 2700 \\
\text { North \& N } 800 \text { East }\end{array}$ \\
\hline 51 & Blue Dome & GSS & Blue Dome \\
\hline 52 & EFS & GSS & $\begin{array}{l}\text { Experimental Field Station - West of } \\
\text { facility fence }\end{array}$ \\
\hline 53 & Arco & GSS & $\begin{array}{l}\text { Arco - NOAA tower } 0.5 \text { miles south of } \\
\text { U.S. HWY } 20 / 26 \text { mile marker } 249\end{array}$ \\
\hline
\end{tabular}


Table A-6. (continued).

\begin{tabular}{|l|l|l|l|}
\hline EMP_REF_ID & \multicolumn{1}{|c|}{ LOC_NAME } & CON_ID & \multicolumn{1}{c|}{ LOCATION DESCRIPTION } \\
\hline 54 & Atomic City & GSS & Atomic City at NOAA tower \\
\hline 658 & Howe & GSS & Howe \\
\hline 661 & Sugar City & GSS & Sugar City \\
\hline 698 & 2 INCH AIR - SUGAR & GSS & Sugar City \\
\hline
\end{tabular}


Table A-7. Drinking Water Monitoring Locations.

\begin{tabular}{|c|c|c|c|}
\hline EMP_REF_ID & LOC_NAME & CON_ID & LOCATION DESCRIPTION \\
\hline 96 & TAN/TSF-613 (WELL \#2) & BEA & TAN/TSF - Inside facility fence \\
\hline 97 & $\begin{array}{l}\text { TAN/TSF-610 } \\
\text { MANIFOLD }\end{array}$ & BEA & TAN/TSF - Inside facility fence \\
\hline 98 & $\begin{array}{l}\text { TAN/CTF- } 614 \\
\text { MANIFOLD }\end{array}$ & BEA & TAN/SMC - Inside facility fence east of SMC \\
\hline 99 & TAN/CTF-632 (WELL \#1) & BEA & TAN/SMC - Inside facility fence east of SMC \\
\hline 100 & TAN/CTF-639 (WELL \#2) & BEA & TAN/SMC - Inside facility fence east of SMC \\
\hline 101 & MFC-754 Manifold & BEA & MFC - Inside facility fence west of MFC-707 \\
\hline 102 & TRA-650 (WELL \#3) & BEA & $\begin{array}{l}\text { ATR Complex - Outside facility fence near } \\
\text { northeast corner }\end{array}$ \\
\hline 103 & TRA-608 MANIFOLD & BEA & $\begin{array}{l}\text { ATR Complex - Inside facility fence near } \\
\text { northeast corner }\end{array}$ \\
\hline 104 & TRA-672 (WELL \#4) & BEA & $\begin{array}{l}\text { ATR Complex - Inside facility fence near } \\
\text { northeast corner }\end{array}$ \\
\hline 105 & TRA-601 (WELL \#1) & BEA & $\begin{array}{l}\text { ATR Complex - Inside facility fence near } \\
\text { northeast corner }\end{array}$ \\
\hline 108 & B21-608 GUN RANGE & BEA & CFA Rifle Range Building B21-608 \\
\hline 109 & CFA-1603 MANIFOLD & BEA & CFA - Facility center \\
\hline 110 & CFA-642 (WELL \#2) & BEA & CFA - Facility center \\
\hline 111 & CFA-651 (WELL \#1) & BEA & CFA - Facility center \\
\hline 112 & B27-603 MAIN GATE & BEA & Main Guard Gate \\
\hline 113 & PBF-614 (WELL \#2) & BEA & CITRC - At PBF Support Area \\
\hline 114 & PBF-602 (WELL \#1) & BEA & CITRC - At PBF Support Area \\
\hline 115 & PBF-638 MANIFOLD & BEA & CITRC - At PBF Support Area \\
\hline 116 & EBR-601 WELL & BEA & EBR - At main building \\
\hline 119 & TRA-696 WELL & BEA & $\begin{array}{l}\text { ATR Complex - Inside facility fence near } \\
\text { northeast corner }\end{array}$ \\
\hline 106 & CPP-1767 Sump & CWI & North of INTEC \\
\hline 107 & CPP-614 & CWI & INTEC - Inside of facility fence \\
\hline 117 & WMF-603 & CWI & RWMC - In Operations Area \\
\hline 118 & WMF-604 & CWI & RWMC - In Operations Area \\
\hline 86 & Idaho Falls & GSS & Idaho Falls \\
\hline 87 & Howe & GSS & Howe (private well) - Near general store \\
\hline
\end{tabular}


Table A-7. (continued).

\begin{tabular}{|l|l|l|l|}
\hline EMP_REF_ID & \multicolumn{1}{|c|}{ LOC_NAME } & CON_ID & \multicolumn{1}{c|}{ LOCATION DESCRIPTION } \\
\hline 88 & May 2011 Howe & GSS & Howe - West of town center \\
\hline 89 & $\begin{array}{l}\text { Mud Lake Well \#2 } \\
\text { (Control) }\end{array}$ & GSS & $\begin{array}{l}\text { Mud Lake Well \#2 (Control) north of State } \\
\text { HWY 33 }\end{array}$ \\
\hline 90 & Rest Area & GSS & $\begin{array}{l}\text { Big Lost River Rest Area on U.S. Highway } \\
\text { 20/26 }\end{array}$ \\
\hline 91 & Atomic City & GSS & $\begin{array}{l}\text { Atomic City - North central end of town south of } \\
\text { Taber Rd. }\end{array}$ \\
\hline 93 & Minidoka & GSS & Minidoka \\
\hline 94 & Shoshone & GSS & Shoshone \\
\hline
\end{tabular}


Table A-8. Surface Water Surveillance Locations.

\begin{tabular}{|c|c|c|c|}
\hline EMP_REF_ID & LOC_NAME & CON_ID & LOCATION DESCRIPTION \\
\hline 630 & SDA Lift Station & CWI & $\begin{array}{l}\text { RWMC - Inside of the SDA on the south end of } \\
\text { ARP V }\end{array}$ \\
\hline 617 & $\begin{array}{l}\text { BLR Control (Birch } \\
\text { Creek) }\end{array}$ & GSS & State HWY 22 mile marker 41 \\
\hline 618 & BLR at EFS & GSS & $\begin{array}{l}\text { Experimental Field Station - Northeast of } \\
\text { facility fence }\end{array}$ \\
\hline 619 & BLR at NRF & GSS & Lincoln Blvd. bridge northeast of NRF \\
\hline 620 & BLR at INTEC & GSS & $\begin{array}{l}\text { BLR at INTEC - Just west of Lincoln Blvd. } \\
\text { bridge }\end{array}$ \\
\hline 621 & BLR AT Rest Area & GSS & $\begin{array}{l}\text { Big Lost River Rest Area on U.S. Highway } \\
\text { 20/26 }\end{array}$ \\
\hline 622 & Alpheus Springs & GSS & Alpheus Springs \\
\hline 623 & Bill Jones Fish Farm & GSS & Bill Jones Fish Farm \\
\hline 624 & Clear Spring & GSS & Clear Spring \\
\hline 657 & BLR Sinks & GSS & Big Lost River Sinks \\
\hline 625 & $\begin{array}{l}\text { Big Lost River near } \\
\text { Mackay }\end{array}$ & USGS & Mackay \\
\hline 626 & Little Lost River & USGS & Howe \\
\hline 627 & Mud Lake & USGS & $\begin{array}{l}\text { Terreton - Northeast of State HWY } 53 \text { mile } \\
\text { marker }\end{array}$ \\
\hline 628 & $\begin{array}{l}\text { Big Lost River near } \\
\text { Arco }\end{array}$ & USGS & $\begin{array}{l}\text { Arco - } 2 \text { miles south of U.S. HWY 20/26 mile } \\
\text { marker } 251\end{array}$ \\
\hline 629 & Birch Creek & USGS & $\begin{array}{l}\text { Blue Dome - East of State Highway } 28 \text { near } \\
\text { mile marker } 45\end{array}$ \\
\hline 631 & $\begin{array}{l}\text { Big Lost River@ } \\
\text { Experimental Field } \\
\text { Station }\end{array}$ & USGS & $\begin{array}{l}\text { Experimental Field Station - North of facility } \\
\text { fence }\end{array}$ \\
\hline 632 & BLR@ INEL Diversion & USGS & $\begin{array}{l}\text { Big Lost River Diversion near USGS gauging } \\
\text { station }\end{array}$ \\
\hline
\end{tabular}


Table A-9. Soil Surveillance Locations.

\begin{tabular}{|c|c|c|c|}
\hline EMP_REF_ID & LOC_NAME & CON_ID & LOCATION DESCRIPTION \\
\hline 263 & ARA-1 & BEA & ARA - North of ARA I \& II \\
\hline 264 & ARA-14 & BEA & ARA - South of ARA I \& II \\
\hline 266 & ARA-16 & BEA & ARA - South of ARA I \& II \\
\hline 267 & ARA-2 & BEA & ARA - North of ARA I \& II \\
\hline 268 & ARA-24 & BEA & ARA - South of ARA I \& II \\
\hline 269 & ARA-28 & BEA & ARA - South of ARA I \& II \\
\hline 270 & ARA-29 & BEA & ARA - South of ARA I \& II \\
\hline 272 & ARA-31 & BEA & ARA - North of ARA I \& II \\
\hline 273 & ARA-32 & BEA & ARA - North of ARA I \& II \\
\hline 274 & ARA-34 & BEA & ARA - North of ARA I \& II \\
\hline 275 & ARA-38 & BEA & ARA - West of ARA I \& II \\
\hline 276 & ARA-4 & BEA & ARA - North of ARA I \& II \\
\hline 278 & ARA-42 & BEA & ARA - West of ARA I \& II \\
\hline 279 & ARA-43 & BEA & ARA - West of ARA I \& II \\
\hline 280 & ARA-47 & BEA & ARA - West of ARA I \& II \\
\hline 281 & ARA-50 & BEA & ARA - West of ARA I \& II \\
\hline 282 & ARA-51 & BEA & ARA - West of ARA I \& II \\
\hline 283 & ARA-62 & BEA & ARA - North of ARA I \& II \\
\hline 284 & ARA-65 & BEA & ARA - North of ARA I \& II \\
\hline 285 & ARA-71 & BEA & ARA - East of ARA I \& II \\
\hline 286 & ARA-74 & BEA & ARA - East of ARA I \& II \\
\hline 287 & ARA-75 & BEA & ARA - East of ARA I \& II \\
\hline 288 & ARA-77 & BEA & ARA - East of ARA I \& II \\
\hline 289 & ARA-9 & BEA & ARA - East of ARA I \& II \\
\hline 290 & EBR2-1 & BEA & MFC - North of facility fence \\
\hline 291 & EBR2-10 & BEA & MFC - North of facility fence \\
\hline 292 & EBR2-11 & BEA & MFC - North of facility fence \\
\hline 293 & EBR2-12 & BEA & MFC - East of facility fence \\
\hline 294 & EBR2-13 & BEA & MFC - East of facility fence \\
\hline 295 & EBR2-15 & BEA & MFC - West of facility fence \\
\hline 296 & EBR2-16 & BEA & MFC - West of facility fence \\
\hline 297 & EBR2-17 & BEA & MFC - West of facility fence \\
\hline
\end{tabular}


Table A-9. (continued).

\begin{tabular}{|c|c|c|c|}
\hline EMP_REF_ID & LOC_NAME & CON_ID & LOCATION DESCRIPTION \\
\hline 298 & EBR2-2 & BEA & MFC - South of facility fence \\
\hline 299 & EBR2-3 & BEA & MFC - East of facility fence \\
\hline 300 & EBR2-4 & BEA & MFC - East of facility fence \\
\hline 301 & EBR2-6 & BEA & MFC - North of facility fence \\
\hline 302 & TRT-1 & BEA & MFC/TREAT - North of facility fence \\
\hline 303 & TRT-2 & BEA & MFC/TREAT - East of facility fence \\
\hline 304 & TRT-3 & BEA & MFC/TREAT - West of facility fence \\
\hline 305 & TRT-4 & BEA & MFC/TREAT - West of facility fence \\
\hline 306 & INA-16 & BEA & INTEC - East of facility fence \\
\hline 307 & INA-17 & BEA & INTEC - East of facility fence \\
\hline 308 & INA-27 & BEA & INTEC - East of facility fence \\
\hline 309 & INA-28 & BEA & INTEC - East of facility fence \\
\hline 310 & INA-4 & BEA & INTEC - East of facility fence \\
\hline 311 & INA-44 & BEA & INTEC - North of facility fence \\
\hline 312 & INA-47 & BEA & INTEC - North of facility fence \\
\hline 313 & INA55 & BEA & INTEC - North of facility fence \\
\hline 314 & INA58 & BEA & INTEC - North of facility fence \\
\hline 315 & INA-6 & BEA & INTEC - East of facility fence \\
\hline 316 & INA-66 & BEA & INTEC - North of facility fence \\
\hline 317 & INA69 & BEA & INTEC - North of facility fence \\
\hline 318 & INA-70 & BEA & INTEC - North of facility fence \\
\hline 319 & INB-101 & BEA & INTEC - South of facility fence \\
\hline 320 & INB-17 & BEA & INTEC - West of facility fence \\
\hline 321 & INB-28 & BEA & INTEC - West of facility fence \\
\hline 322 & INB-29 & BEA & INTEC - West of facility fence \\
\hline 323 & INB-4 & BEA & INTEC - West of facility fence \\
\hline 324 & INB-40 & BEA & INTEC - West of facility fence \\
\hline 325 & INB-50 & BEA & INTEC - West of facility fence \\
\hline 326 & INB-52 & BEA & INTEC - West of facility fence \\
\hline 327 & INB71 & BEA & ICDF - Inside facility fence \\
\hline 328 & INB-80 & BEA & ICDF - Inside facility fence \\
\hline 329 & INB89 & BEA & INTEC - South of facility fence \\
\hline
\end{tabular}


Table A-9. (continued).

\begin{tabular}{|c|c|c|c|}
\hline EMP_REF_ID & LOC_NAME & CON_ID & LOCATION DESCRIPTION \\
\hline 330 & INB-90 & BEA & INTEC - South of facility fence \\
\hline 331 & INB-91 & BEA & INTEC - South of facility fence \\
\hline 332 & INB-99 & BEA & INTEC - South of facility fence \\
\hline 333 & INC-15 & BEA & INTEC - West of facility fence \\
\hline 334 & INC-25 & BEA & INTEC - West of facility fence \\
\hline 335 & INC-46 & BEA & INTEC - North of facility fence \\
\hline 336 & INC-48 & BEA & INTEC - North of facility fence \\
\hline 337 & INC-56 & BEA & INTEC - North of facility fence \\
\hline 338 & INC-57 & BEA & INTEC - North of facility fence \\
\hline 339 & IND-56 & BEA & INTEC - East of facility fence \\
\hline 340 & IND-68 & BEA & INTEC - South of facility fence \\
\hline 341 & IND-89 & BEA & INTEC - South of facility fence \\
\hline 342 & IND-91 & BEA & INTEC - South of facility fence \\
\hline 343 & INT-A15 & BEA & INTEC - East of facility fence \\
\hline 344 & INT-A38 & BEA & INTEC - East of facility fence \\
\hline 345 & INT-A39 & BEA & INTEC - East of facility fence \\
\hline 346 & INT-A49 & BEA & INTEC - North of facility fence \\
\hline 347 & INT-A50 & BEA & INTEC - North of facility fence \\
\hline 348 & INT-A59 & BEA & INTEC - North of facility fence \\
\hline 349 & INT-A61 & BEA & INTEC - North of facility fence \\
\hline 350 & INT-A72 & BEA & INTEC - North of facility fence \\
\hline 351 & INT-B102 & BEA & INTEC - South of facility fence \\
\hline 352 & INT-B103 & BEA & INTEC - South of facility fence \\
\hline 353 & INT-B104 & BEA & INTEC - South of facility fence \\
\hline 354 & INT-B106 & BEA & INTEC - Southwest of facility fence \\
\hline 355 & INT-B14 & BEA & INTEC - West of facility fence \\
\hline 357 & INT-B15 & BEA & INTEC - West of facility fence \\
\hline 358 & INT-B25 & BEA & INTEC - West of facility fence \\
\hline 359 & INT-B3 & BEA & INTEC - West of facility fence \\
\hline 360 & INT-B48 & BEA & INTEC - West of facility fence \\
\hline 362 & INT-B61 & BEA & INTEC - West of facility fence \\
\hline 363 & INT-B62 & BEA & INTEC - West of facility fence \\
\hline
\end{tabular}


Table A-9. (continued).

\begin{tabular}{|c|c|c|c|}
\hline EMP_REF_ID & LOC_NAME & CON_ID & LOCATION DESCRIPTION \\
\hline 364 & INT-B73 & BEA & INTEC - Southwest of facility fence \\
\hline 365 & INT-B83 & BEA & INTEC - Southwest of facility fence \\
\hline 366 & INT-B84 & BEA & INTEC - Southwest of facility fence \\
\hline 367 & INT-B92 & BEA & INTEC - South of facility fence \\
\hline 368 & INT-B93 & BEA & INTEC - South of facility fence \\
\hline 369 & INT-B94 & BEA & INTEC - Southwest of facility fence \\
\hline 370 & INT-D58 & BEA & INTEC - East of facility fence \\
\hline 371 & LG-1 & BEA & T-Road 8 - East of road (Large Grid) \\
\hline 372 & LG-10 & BEA & T-Road 9 - North of road (Large Grid) \\
\hline 373 & LG-11 & BEA & T-Road 22 - Northwest of road (Large Grid) \\
\hline 374 & LG-12 & BEA & T-Road 22 - Southeast of road (Large Grid) \\
\hline 375 & LG-13 & BEA & T-Road 4 - East of road $\sim 2$ miles (Large Grid) \\
\hline 376 & LG-14 & BEA & T-Road 20 - North of road (Large Grid) \\
\hline 377 & LG-15 & BEA & $\begin{array}{l}\text { U.S. HWY } 20 \sim 0.8 \text { miles north of mile marker } 282 \\
\text { (Large Grid) }\end{array}$ \\
\hline 378 & LG-16 & BEA & $\begin{array}{l}\text { U.S. HWY } 20 \sim 0.5 \text { miles northwest of mile marker } 279 \\
\text { (Large Grid) }\end{array}$ \\
\hline 379 & LG-17 & BEA & East Butte - North of butte $\sim 1.4$ miles (Large Grid) \\
\hline 380 & LG-18 & BEA & East Butte - South of butte (Large Grid) \\
\hline 381 & LG-19 & BEA & Middle Butte - Northeast of butte (Large Grid) \\
\hline 382 & LG-2 & BEA & T-Road 9 - East of road (Large Grid) \\
\hline 383 & LG-20 & BEA & Atomic City - West of butte $\sim 4$ miles (Large Grid) \\
\hline 384 & LG-21 & BEA & Middle Butte - West of butte $\sim 1.5$ miles (Large Grid) \\
\hline 385 & LG-22 & BEA & Atomic City - Northwest of city $\sim 4$ miles (Large Grid) \\
\hline 387 & LG-23 & BEA & $\begin{array}{l}\text { CFA - South of facility and U.S. HWY 20/26 (Large } \\
\text { Grid) }\end{array}$ \\
\hline 388 & LG-24 & BEA & RWMC - Southeast of facility (Large Grid) \\
\hline 389 & LG-25 & BEA & RWMC - South of facility fence (Large Grid) \\
\hline 390 & LG-26 & BEA & ATR Complex - West of facility fence (Large Grid) \\
\hline 391 & LG-27 & BEA & U.S. HWY 20/26 south of mile marker 260 (Large Grid) \\
\hline 392 & LG-28 & BEA & U.S. HWY 20/26 east of mile marker 257 (Large Grid) \\
\hline 393 & LG-29 & BEA & ATR Complex - West of facility fence (Large Grid) \\
\hline 394 & LG-3 & BEA & RWMC - Northwest of facility fence (Large Grid) \\
\hline
\end{tabular}


Table A-9. (continued).

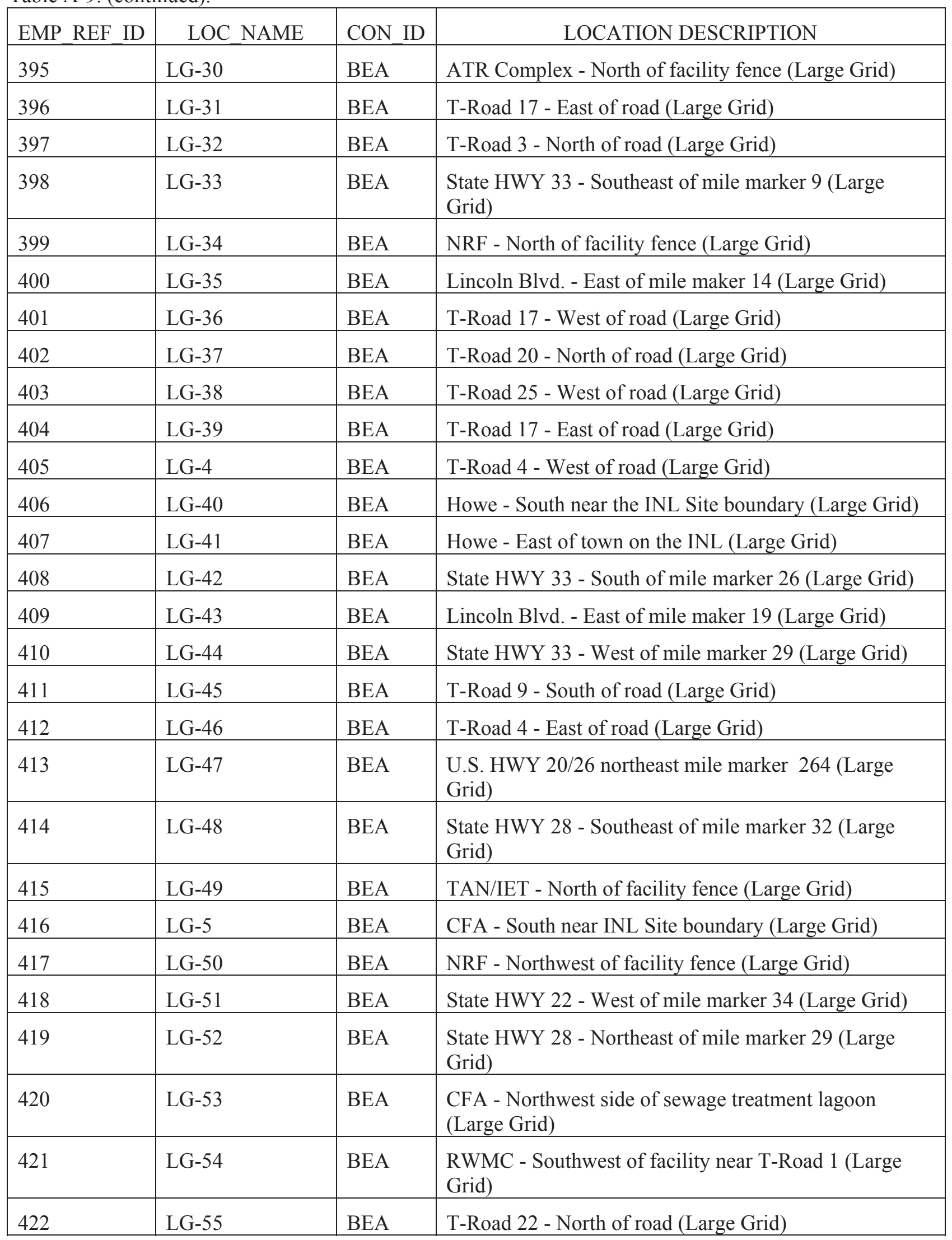


Table A-9. (continued).

\begin{tabular}{|c|c|c|c|}
\hline \\
\hline EMP_REF_ID & LOC_NAME & CON_ID & LOCATION DESCRIPTION \\
\hline 423 & LG-56 & BEA & $\begin{array}{l}\text { East of ARA near new MFC/CITRC haul road (Large } \\
\text { Grid) }\end{array}$ \\
\hline 424 & LG-57 & BEA & State HWY 22 - West of mile marker 28 (Large Grid) \\
\hline 425 & LG-58 & BEA & $\begin{array}{l}\text { Atomic City - Northwest of city } \sim 1.7 \text { miles (Large } \\
\text { Grid) }\end{array}$ \\
\hline 426 & LG-59 & BEA & NRF - North of facility fence (Large Grid) \\
\hline 427 & LG-6 & BEA & Northeast corner of site near farm land (Large Grid) \\
\hline 428 & LG-60 & BEA & Atomic City - West of butte $\sim 2.2$ miles (Large Grid) \\
\hline 429 & LG-61 & BEA & T-Road 4 - (Large Grid) \\
\hline 430 & LG-7 & BEA & State HWY 28 - West of mile marker 20 (Large Grid) \\
\hline 431 & LG-8 & BEA & State HWY 28 - West of mile marker 23 (Large Grid) \\
\hline 432 & LG-9 & BEA & State HWY 33 - North of mile marker 37 (Large Grid) \\
\hline 433 & NRF-12 & BEA & NRF - West of facility fence \\
\hline 434 & NRF-14 & BEA & NRF - South of facility fence \\
\hline 435 & NRF-6 & BEA & NRF - East of facility fence \\
\hline 436 & NRF-7 & BEA & NRF - North of facility fence \\
\hline 437 & NRF-8 & BEA & NRF - North of facility fence \\
\hline 438 & PBF-1 & BEA & CITRC - At PBF Support Area \\
\hline 439 & PBF-10 & BEA & CITRC - South of PBF Support Area on perimeter fence \\
\hline 440 & PBF-11 & BEA & CITRC - West of PBF Support Area on perimeter fence \\
\hline 441 & PBF-2 & BEA & CITRC - West of PBF Control Area on perimeter fence \\
\hline 442 & PBF-3 & BEA & CITRC - West of PBF Control Area on perimeter fence \\
\hline 443 & PBF-5 & BEA & CITRC - North of PBF Control Area on perimeter fence \\
\hline 444 & PBF-6 & BEA & CITRC - North of PBF Control Area on perimeter fence \\
\hline 445 & PBF-7 & BEA & $\begin{array}{l}\text { CITRC - North of Special Programs Facility on } \\
\text { perimeter fence }\end{array}$ \\
\hline 446 & PBF-8 & BEA & $\begin{array}{l}\text { CITRC - East of Incident Response Training and } \\
\text { Testing Center on perimeter fence }\end{array}$ \\
\hline 447 & PBF-9 & BEA & CITRC - South near perimeter fence along Wilson Blvd. \\
\hline 448 & WERF800A & BEA & $\begin{array}{l}\text { CITRC - East of Incident Response Training and } \\
\text { Testing Center on perimeter fence }\end{array}$ \\
\hline 449 & WERF800B & BEA & $\begin{array}{l}\text { CITRC - East of Incident Response Training and } \\
\text { Testing Center on perimeter fence }\end{array}$ \\
\hline
\end{tabular}


Table A-9. (continued).

\begin{tabular}{|c|c|c|c|}
\hline EMP_REF_ID & LOC_NAME & CON_ID & LOCATION DESCRIPTION \\
\hline 450 & WERF800C & BEA & $\begin{array}{l}\text { CITRC - East of Incident Response Training and } \\
\text { Testing Center on perimeter fence }\end{array}$ \\
\hline 451 & WERF800D & BEA & $\begin{array}{l}\text { CITRC - East of Incident Response Training and } \\
\text { Testing Center on perimeter fence }\end{array}$ \\
\hline 452 & WERF800E & BEA & $\begin{array}{l}\text { CITRC - East of Incident Response Training and } \\
\text { Testing Center on perimeter fence }\end{array}$ \\
\hline 453 & RW10-1 & BEA & EBR-I - West of facility fence \\
\hline 454 & RW2-1 & BEA & RWMC - North of facility fence \\
\hline 455 & RW2-4 & BEA & RWMC - North of facility fence \\
\hline 456 & RW2-6 & BEA & RWMC - North of facility fence \\
\hline 457 & RW2-8 & BEA & RWMC - North of facility fence \\
\hline 458 & RW3-4 & BEA & RWMC - North of facility fence \\
\hline 459 & RW3-6 & BEA & RWMC - North of facility fence \\
\hline 460 & RW3-8 & BEA & RWMC - North of facility fence \\
\hline 461 & RW4-1 & BEA & RWMC - North of facility fence \\
\hline 462 & RW4-5 & BEA & RWMC - North of facility fence \\
\hline 463 & RW5-12 & BEA & RWMC - North of facility fence \\
\hline 464 & RW5-4 & BEA & RWMC - North of facility fence \\
\hline 465 & RW5-7 & BEA & RWMC - North of facility fence \\
\hline 466 & RW6-1 & BEA & RWMC - South of facility fence \\
\hline 467 & RW6-3 & BEA & RWMC - South of facility fence \\
\hline 468 & RW6-7 & BEA & RWMC - West of facility fence \\
\hline 469 & RW7-2 & BEA & RWMC - South of facility fence \\
\hline 470 & RW8-1 & BEA & RWMC - South of facility fence \\
\hline 471 & RW8-5 & BEA & RWMC - West of facility fence \\
\hline 472 & RW9-1 & BEA & INTEC - Southwest of facility fence \\
\hline 473 & RTC8-2 & BEA & ATR Complex - South of facility fence \\
\hline 474 & TRA.0.3 & BEA & ATR Complex - East of facility fence \\
\hline 475 & TRA.-1.1 & BEA & ATR Complex - East of facility fence \\
\hline 476 & TRA.-1.2 & BEA & ATR Complex - East of facility fence \\
\hline 477 & TRA.1.3 & BEA & ATR Complex - East of facility fence \\
\hline 478 & TRA.-1.3 & BEA & ATR Complex - East of facility fence \\
\hline 479 & TRA.1.4 & BEA & ATR Complex - East of facility fence \\
\hline
\end{tabular}


Table A-9. (continued).

\begin{tabular}{|c|c|c|c|}
\hline EMP REF ID & LOC NAME & CON ID & LOCATION DESCRIPTION \\
\hline 480 & TRA.-2.2 & BEA & ATR Complex - East of facility fence \\
\hline 481 & TRA.2.3 & BEA & ATR Complex - East of facility fence \\
\hline 482 & TRA.-2.3 & BEA & ATR Complex - East of facility fence \\
\hline 483 & TRA-6.4 & BEA & ATR Complex - South of facility fence \\
\hline 484 & TRA6-2 & BEA & ATR Complex - South of facility fence \\
\hline 485 & TRA-A 1.2 & BEA & ATR Complex - East of facility fence \\
\hline 486 & TRA-A1.3 & BEA & ATR Complex - North of facility fence \\
\hline 487 & TRA-A2.2 & BEA & ATR Complex - East of facility fence \\
\hline 488 & TRA-A2.3 & BEA & ATR Complex - North of facility fence \\
\hline 490 & TRA-A2.4 & BEA & ATR Complex - North of facility fence \\
\hline 491 & TRA-A3.2 & BEA & ATR Complex - North of facility fence \\
\hline 492 & TRA-A3.4 & BEA & ATR Complex - North of facility fence \\
\hline 493 & TRA-A3.5 & BEA & ATR Complex - North of facility fence \\
\hline 494 & TRA-A 4.5 & BEA & ATR Complex - North of facility fence \\
\hline 495 & WRTF-5 & BEA & TAN/WRRTF - northeast perimeter fence \\
\hline 496 & WRTF-6 & BEA & TAN/WRRTF - southeast perimeter fence \\
\hline 497 & WRTF-7 & BEA & TAN/WRRTF - southwest perimeter fence \\
\hline 498 & WRTF-8 & BEA & TAN/WRRTF - northwest perimeter fence \\
\hline 499 & L2-76 & BEA & TAN/SMC - North of facility fence (Large Grid) \\
\hline 500 & L3-76 & BEA & TAN/SMC - South of facility fence (Large Grid) \\
\hline 501 & L4-76 & BEA & TAN/SMC - South of facility fence (Large Grid) \\
\hline 502 & L5-76 & BEA & TAN/SMC - South of facility fence (Large Grid) \\
\hline 503 & TSF7 & BEA & TAN/TSF - South facility fence \\
\hline 504 & TAN-1 & BEA & TAN/TSF - South facility fence \\
\hline 505 & TAN-6 & BEA & TAN/TSF - South facility fence \\
\hline 506 & TAN-8 & BEA & TAN/TSF - South facility fence \\
\hline 507 & TAN-9 & BEA & TAN/TSF - South facility fence \\
\hline 508 & IET-6 & BEA & TAN/IET - East of facility fence \\
\hline 509 & IET-7 & BEA & TAN/IET - East of facility fence \\
\hline 510 & IET-8 & BEA & TAN/IET - North of facility fence (Large Grid) \\
\hline 511 & IET-9 & BEA & TAN/IET - North of facility fence (Large Grid) \\
\hline 512 & $1-1$ & CWI & RWMC/TSA - AMWTP facility area \\
\hline
\end{tabular}


Table A-9. (continued).

\begin{tabular}{|c|c|c|c|}
\hline \\
\hline EMP_REF_ID & LOC_NAME & CON_ID & LOCATION DESCRIPTION \\
\hline 513 & $1-2$ & CWI & RWMC/SDA - Inside facility fence \\
\hline 514 & $2-1$ & CWI & RWMC/SDA - Inside facility fence \\
\hline 515 & $2-3$ & CWI & RWMC/SDA - Inside facility fence \\
\hline 516 & $2-4$ & CWI & RWMC/SDA - Inside facility fence \\
\hline 517 & $2-5$ & CWI & RWMC/SDA - Inside facility fence \\
\hline 518 & $3-1$ & CWI & RWMC/SDA - Inside facility fence \\
\hline 519 & $3-2$ & CWI & RWMC/SDA - Inside facility fence \\
\hline 520 & $3-3$ & CWI & RWMC/SDA - Inside facility fence \\
\hline 521 & $5-4$ & CWI & RWMC/TSA - AMWTP facility area \\
\hline 522 & $3-5$ & CWI & RWMC/SDA - Inside facility fence \\
\hline 523 & $\mathrm{~T}-12$ & CWI & U.S. HWY 20/26 west of mile marker 266 on T-Road 12 \\
\hline 524 & $\mathrm{~T}-13$ & CWI & Spreading Area B (north end) \\
\hline 525 & Atomic City & GSS & Near Atomic City on T-4 0.7 miles east of U.S. 26 \\
\hline 526 & Butte City & GSS & Butte City - 1.3 miles south of mile post 252 \\
\hline 527 & $\begin{array}{l}\text { Frenchman's } \\
\text { Cabin }\end{array}$ & GSS & Frenchman's Cabin \\
\hline 528 & FAA Tower & GSS & FAA Tower - US HWY 20 west of mile marker 282 \\
\hline 529 & Howe & GSS & $\begin{array}{l}\text { Howe - just north of mile marker } 10.3 \text { on State HWY } 33 \\
\text { east of Howe }\end{array}$ \\
\hline 530 & Reno Ranch & GSS & $\begin{array}{l}\text { Reno Ranch - } 0.3 \text { miles north of mile marker } 40 \text { on State } \\
\text { HWY } 22\end{array}$ \\
\hline 531 & Monteview & GSS & Monteview \\
\hline 532 & Mudlake \#1 & GSS & $\begin{array}{l}\text { Mud Lake - } 0.3 \text { miles north of mile marker } 16 \text { on State } \\
\text { HWY } 28\end{array}$ \\
\hline 533 & Mudlake \#2 & GSS & $\begin{array}{l}\text { Mud Lake - } 4.2 \text { miles south of mile marker } 44 \text { on State } \\
\text { HWY } 33\end{array}$ \\
\hline 534 & Carey & GSS & Carey \\
\hline 535 & St. Anthony & GSS & St. Anthony \\
\hline 536 & Crystal Ice Caves & GSS & Crystal Ice Caves \\
\hline 537 & Blackfoot & GSS & Blackfoot \\
\hline
\end{tabular}


Table A-10. Biota Surveillance Locations.

\begin{tabular}{|l|l|l|l|}
\hline EMP_REF_ID & \multicolumn{1}{|c|}{ LOC_NAME } & CON_ID & \multicolumn{1}{|c|}{ LOCATION DESCRIPTION } \\
\hline 683 & Area 1 & CWI & RWMC/SDA - Inside facility fence \\
\hline 684 & Area 1 & CWI & RWMC/SDA - Inside facility fence \\
\hline 685 & Area 1 & CWI & RWMC/SDA - Inside facility fence \\
\hline 686 & Area 3 & CWI & RWMC/SDA - Inside facility fence \\
\hline 688 & Area 3 & CWI & RWMC/SDA - Inside facility fence \\
\hline 689 & Area 2 & CWI & RWMC/SDA - Pad A \\
\hline 691 & Area 2 & CWI & RWMC/SDA - Pad A \\
\hline 692 & Frea 2 & CWI & RWMC/SDA - Pad A \\
\hline 693 & Frenchmans Cabin & CWI & $\begin{array}{l}\text { Big Southern Butte - North end of the runway at } \\
\text { Frenchman's Cabin }\end{array}$ \\
\hline 694 & Frenchmans Cabin & CWI & $\begin{array}{l}\text { Big Southern Butte - North end of the runway at } \\
\text { Frenchman's Cabin }\end{array}$ \\
\hline 695 & Frenchmans Cabin & CWI & $\begin{array}{l}\text { Big Southern Butte - North end of the runway at } \\
\text { Frenchman's Cabin }\end{array}$ \\
\hline 696 & Frenchmans Cabin & CWI & $\begin{array}{l}\text { Big Southern Butte - North end of the runway at } \\
\text { Frenchman's Cabin }\end{array}$ \\
\hline
\end{tabular}


Table A-11. Agricultural Products Surveillance Locations.

\begin{tabular}{|c|c|c|c|c|}
\hline EMP_REF_ID & LOC_NAME & MEDIA & CON_ID & LOCATION DESCRIPTION \\
\hline 664 & Terreton & Alfalfa & GSS & $\begin{array}{l}\text { Mud Lake - Southwest Corner of N } 1200 \\
\text { East \& State } 33\end{array}$ \\
\hline 4 & Monteview & Lettuce & GSS & $\begin{array}{l}\text { Monteview - Near intersection of E } 2700 \\
\text { North \& N } 800 \text { East }\end{array}$ \\
\hline 5 & Howe & Lettuce & GSS & State HWY 33 mile marker 22 \\
\hline 8 & FAA Tower & Lettuce & GSS & $\begin{array}{l}\text { FAA Tower - U.S. HWY } 20 \text { west of mile } \\
\text { marker } 282\end{array}$ \\
\hline 9 & EFS & Lettuce & GSS & $\begin{array}{l}\text { Experimental Field Station - West of } \\
\text { facility fence }\end{array}$ \\
\hline 11 & Arco & Lettuce & GSS & $\begin{array}{l}\text { Arco - NOAA tower } 0.5 \text { miles south of } \\
\text { U.S. HWY } 20 / 26 \text { mile marker } 249\end{array}$ \\
\hline 14 & Atomic City & Lettuce & GSS & Atomic City at NOAA tower \\
\hline 17 & Blackfoot & Lettuce & GSS & Blackfoot \\
\hline 18 & Carey & Lettuce & GSS & Carey \\
\hline 1 & Idaho Falls (Reed's Dairy) & Milk & GSS & Idaho Falls - Reed's Dairy \\
\hline 16 & Astle Dairy & Milk & GSS & Astle Dairy \\
\hline 19 & Fort Hall & Milk & GSS & Fort Hall \\
\hline 21 & Minidoka & Milk & GSS & Minidoka \\
\hline 31 & Terreton & Milk & GSS & Terreton \\
\hline 665 & Terreton & Milk & GSS & $\begin{array}{l}\text { Mud Lake }-0.3 \text { miles East of N } 1200 \text { East } \\
\text { on E } 1700 \text { North }\end{array}$ \\
\hline 699 & Howe & Milk & GSS & Callister Dairy north of Howe \\
\hline 700 & Blackfoot & Milk & GSS & Groneman Dairy in Blackfoot \\
\hline 3 & Idaho Falls & Potato & GSS & Idaho Falls \\
\hline 6 & Mud Lake & Potato & GSS & $\begin{array}{l}\text { Mud Lake - south of State HWY } 33 \text { on N } \\
1100 \text { East }\end{array}$ \\
\hline 10 & Butte City & Potato & GSS & $\begin{array}{l}\text { Butte City - Southwest of U.S. HWY } \\
20 / 26 \text { mile marker } 253\end{array}$ \\
\hline 13 & Arco & Potato & GSS & South of Arco on U.S. 93 \\
\hline 20 & Groveland & Potato & GSS & Groveland \\
\hline 23 & Monteview & Potato & GSS & Monteview - E 2700 North \\
\hline 26 & Rupert & Potato & GSS & Rupert \\
\hline 28 & Shelley & Potato & GSS & Shelley \\
\hline 30 & Terreton & Potato & GSS & Terreton \\
\hline
\end{tabular}


Table A-11. (continued).

\begin{tabular}{|l|l|l|l|l|}
\hline EMP_REF_ID & \multicolumn{1}{|c|}{ LOC_NAME } & MEDIA & CON_ID & \multicolumn{1}{|c|}{ LOCATION DESCRIPTION } \\
\hline 2 & Idaho Falls & Wheat & GSS & Idaho Falls \\
\hline 7 & Terreton & Wheat & GSS & $\begin{array}{l}\text { Terreton - State HWY 33 east of mile } \\
\text { marker 47 }\end{array}$ \\
\hline 12 & Arco & Wheat & GSS & $\begin{array}{l}\text { Arco - West of U.S. HWY 20/26 mile } \\
\text { marker 249 }\end{array}$ \\
\hline 15 & American Falls & Wheat & GSS & American Falls \\
\hline 22 & Monteview & Wheat & GSS & Monteview \\
\hline 24 & Moreland & Wheat & GSS & Moreland \\
\hline 25 & Rupert & Wheat & GSS & Rupert \\
\hline 27 & Rupert & Wheat & GSS & Rupert \\
\hline 29 & Taber & Wheat & GSS & Taber \\
\hline
\end{tabular}


Table A-12. External Radiation Surveillance Locations.

\begin{tabular}{|c|c|c|c|}
\hline EMP_REF_ID & LOC_NAME & CON_ID & LOCATION DESCRIPTION \\
\hline 152 & Hwy28 N2300 O-2 & BEA & $\begin{array}{l}\text { State Highway } 28-0.3 \text { miles north of } \\
\text { mile marker } 27\end{array}$ \\
\hline 153 & Hwy22 T28 O-1 & BEA & $\begin{array}{l}\text { State Highway } 22-0.2 \text { miles north of } \\
\text { mile post } 33\end{array}$ \\
\hline 154 & IDAHO FALLS O-10 & BEA & $\begin{array}{l}\text { Idaho Falls - North of TSA/TSB on east } \\
\text { side of Foote Dr. }\end{array}$ \\
\hline 155 & Idaho Falls IF-627 O-30 & BEA & $\begin{array}{l}\text { Idaho Falls - Located at the INL Research } \\
\text { Center (IRC) facility near Building IF- } \\
627\end{array}$ \\
\hline 156 & Idaho Falls IF-675E O-35 & BEA & $\begin{array}{l}\text { Idaho Falls - PINS Laboratory located } \\
\text { east of Hitt Rd. on E 14th N }\end{array}$ \\
\hline 157 & Idaho Falls IF-675D O-33 & BEA & $\begin{array}{l}\text { Idaho Falls - PINS Laboratory located } \\
\text { east of Hitt Rd. on E 14th N }\end{array}$ \\
\hline 158 & Idaho Falls IF-675S O-34 & BEA & $\begin{array}{l}\text { Idaho Falls - PINS Laboratory located } \\
\text { east of Hitt Rd. on E 14th N }\end{array}$ \\
\hline 159 & Idaho Falls IF-675W O-35 & BEA & $\begin{array}{l}\text { Idaho Falls - PINS Laboratory located } \\
\text { east of Hitt Rd. on E 14th N }\end{array}$ \\
\hline 160 & ATOMIC CITY O-2 & BEA & Atomic City at NOAA tower \\
\hline 161 & TAN LOFT O-7 & BEA & TAN - East of SMC facility fence \\
\hline 162 & TAN LOFT O-6 & BEA & TAN - South of SMC facility fence \\
\hline 163 & Hwy33 T17 O-3 & BEA & State HWY 33 - mile marker 36 \\
\hline 164 & LINCOLNBVLD O-25 & BEA & $\begin{array}{l}\text { TAN - South of TSF facility on State } \\
\text { Highway } 33 \text { (Lincoln Blvd.) }\end{array}$ \\
\hline 165 & NRF O-20 & BEA & NRF - South of facility \\
\hline 166 & NRF O-19 & BEA & NRF - South of facility \\
\hline 167 & NRF O-16 & BEA & NRF - North of facility \\
\hline 168 & NRF O-5 & BEA & NRF - North of facility \\
\hline 169 & NRF O-4 & BEA & NRF - North of facility \\
\hline 170 & NRF O-12 & BEA & NRF - East of facility \\
\hline 171 & LINCOLNBVLD O-9 & BEA & $\begin{array}{l}\text { Lincoln Blvd. mile marker } 9 \text { - east side of } \\
\text { road }\end{array}$ \\
\hline 172 & LINCOLNBVLD O-5 & BEA & $\begin{array}{l}\text { Lincoln Blvd. mile marker } 5 \text { - east side of } \\
\text { road }\end{array}$ \\
\hline 173 & TRA O-13 & BEA & ATR - West of facility \\
\hline 174 & TRA O-11 & BEA & ATR - West of facility \\
\hline 175 & TRA O-10 & BEA & ATR Complex - North of facility \\
\hline
\end{tabular}


Table A-12. (continued).

\begin{tabular}{|c|c|c|c|}
\hline EMP_REF_ID & LOC_NAME & CON_ID & LOCATION DESCRIPTION \\
\hline 176 & TRA O-8 & BEA & ATR - North of facility \\
\hline 177 & TRA O-6 & BEA & ATR - Northeast of facility \\
\hline 178 & TRA O-4 & BEA & ATR - East of facility \\
\hline 179 & TRA O-2 & BEA & ATR -South of facility \\
\hline 180 & ICPP O-19 & BEA & INTEC - West of facility \\
\hline 181 & ICPP TREEFARM O-3 & BEA & INTEC - West of facility \\
\hline 182 & ICPP O-21 & BEA & INTEC - Southwest of facility \\
\hline 183 & ICPP O-23 & BEA & INTEC - Southeast of facility \\
\hline 184 & ICPP O-25 & BEA & INTEC - Southeast of facility \\
\hline 185 & ICPP O-26 & BEA & INTEC - East of facility \\
\hline 186 & ICPP O-15 & BEA & INTEC - Northeast of facility \\
\hline 187 & ICPP O-9 & BEA & INTEC - Northeast of facility \\
\hline 188 & ICPP O-17 & BEA & INTEC - Northwest of facility \\
\hline 189 & LINCOLNBVLD O-3 & BEA & $\begin{array}{l}\text { Lincoln Blvd. south of ICDF - East side } \\
\text { of road }\end{array}$ \\
\hline 190 & CFA O-1 & BEA & CFA - West of Building 690 \\
\hline 191 & LINCOLNBLVD O-1 & BEA & $\begin{array}{l}\text { CFA - East of Lincoln BLVD. near Main } \\
\text { St. intersection }\end{array}$ \\
\hline 192 & PBF SPERT O-1 & BEA & $\begin{array}{l}\text { CITRC - North of Jefferson Rd. and } \\
\text { PBF- } 632 \text { at the former PBF Control Area }\end{array}$ \\
\hline 193 & ARA I\&II O-1 & BEA & ARA - ARA I \& II facility location \\
\hline 194 & Hwy20 Mile O-276 & BEA & $\begin{array}{l}\text { US HWY } 20 \text { and the intersection of } \\
\text { Taylor Blvd. on the east side of the road. }\end{array}$ \\
\hline 195 & ANL W EBR II O-13 & BEA & MFC - Southeast of perimeter fence \\
\hline 196 & ANL W EBR II O-12 & BEA & $\begin{array}{l}\text { MFC - West of perimeter fence near } \\
\text { guard gate }\end{array}$ \\
\hline 197 & ANL W EBR II O-7 & BEA & MFC - West of perimeter fence \\
\hline 198 & ANL W EBR II O-18 & BEA & MFC - West of perimeter fence \\
\hline 199 & ANL W EBR II O-17 & BEA & MFC - North of perimeter fence \\
\hline 200 & ANL W EBR II O-15 & BEA & MFC - Northeast of perimeter fence \\
\hline 201 & ANL W TREAT O-9 & BEA & MFC - North of MFC-721 \\
\hline 202 & EBR I O-1 & BEA & EBR-I - Parking lot \\
\hline 203 & RWMC O-46 & BEA & $\begin{array}{l}\text { RWMC - North of Operation Area } \\
\text { facility fence }\end{array}$ \\
\hline
\end{tabular}


Table A-12. (continued).

\begin{tabular}{|c|c|c|c|}
\hline EMP_REF ID & LOC_NAME & CON_ID & LOCATION DESCRIPTION \\
\hline 204 & RWMC O-9A & BEA & $\begin{array}{l}\text { RWMC - North of SDA facility fence } \\
\text { near north gate }\end{array}$ \\
\hline 205 & RWMC O-13A & BEA & RWMC - North of SDA facility fence \\
\hline 206 & RWMC O-17A & BEA & RWMC - West of facility fence \\
\hline 207 & RWMC O-21A & BEA & RWMC - South of SDA facility fence \\
\hline 208 & RWMC O-25A & BEA & RWMC - South of SDA facility fence \\
\hline 209 & RWMC O-29A & BEA & RWMC - South of SDA facility fence \\
\hline 210 & RWMC O-43 & BEA & RWMC - South of TSA facility fence \\
\hline 211 & RWMC O-41 & BEA & RWMC - East of TSA facility fence \\
\hline 212 & RWMC O-39 & BEA & $\begin{array}{l}\text { RWMC - East of facility fence near main } \\
\text { gate }\end{array}$ \\
\hline 213 & REXBURG O-12 & BEA & $\begin{array}{l}\text { Rexburg - East of Yellowstone Highway } \\
\text { on W 7th St. S }\end{array}$ \\
\hline 633 & ARCO O-1 & BEA & $\begin{array}{l}\text { Arco - NOAA tower } 0.5 \text { miles south of } \\
\text { U.S. HWY } 20 / 26 \text { mile marker } 249\end{array}$ \\
\hline 637 & HOWE O-3 & BEA & Howe \\
\hline 638 & 001 & BEA & Howe \\
\hline 640 & CRATERS of Moon O-7 & BEA & Craters of the Moon \\
\hline 642 & BLACKFOOT O-9 & BEA & $\begin{array}{l}\text { Blackfoot - Mountain View Middle } \\
\text { School }\end{array}$ \\
\hline 647 & ABERDEEN O-8 & BEA & Aberdeen \\
\hline 648 & MINIDOKA O-11 & BEA & Minidoka \\
\hline 649 & RENO RANCH O-6 & BEA & $\begin{array}{l}\text { Reno Ranch - State HWY } 22 \text { mile marker } \\
41\end{array}$ \\
\hline 650 & ROBERTS O-13 & BEA & Roberts \\
\hline 651 & MONTEVIEW O-4 & BEA & $\begin{array}{l}\text { Monteview - Near intersection of E } 2700 \\
\text { North \& N } 800 \text { East }\end{array}$ \\
\hline 652 & MUD LAKE O-5 & BEA & $\begin{array}{l}\text { Mud Lake - South of State HWY } 33 \text { on N } \\
1100 \text { East }\end{array}$ \\
\hline 668 & IF-603W O-4 & $\mathrm{BEA}$ & $\begin{array}{l}\text { Idaho Falls - Located at the INL Research } \\
\text { Center (IRC) facility, west of Building } \\
\text { IF-603 }\end{array}$ \\
\hline 669 & IF-603N O-1 & BEA & $\begin{array}{l}\text { Idaho Falls - Located at the INL Research } \\
\text { Center (IRC) facility, north of Building } \\
\text { IF-603 }\end{array}$ \\
\hline
\end{tabular}


Table A-12. (continued).

\begin{tabular}{|c|c|c|c|}
\hline EMP_REF_ID & LOC_NAME & CON_ID & LOCATION DESCRIPTION \\
\hline 670 & IF-603E O-2 & BEA & $\begin{array}{l}\text { Idaho Falls - Located at the INL Research } \\
\text { Center (IRC) facility, east of Building IF- } \\
603\end{array}$ \\
\hline 671 & IF-603S O-3 & BEA & $\begin{array}{l}\text { Idaho Falls - Located at the INL Research } \\
\text { Center (IRC) facility, south of Building } \\
\text { IF-603 }\end{array}$ \\
\hline 672 & IF-638N O-1 & BEA & $\begin{array}{l}\text { Idaho Falls - Located at the INL Research } \\
\text { Center (IRC) facility, north of Building } \\
\text { IF-638 }\end{array}$ \\
\hline 673 & IF-638W O-4 & BEA & $\begin{array}{l}\text { Idaho Falls - Located at the INL Research } \\
\text { Center (IRC) facility, west of Building } \\
\text { IF-638 }\end{array}$ \\
\hline 674 & IF-638S O-3 & BEA & $\begin{array}{l}\text { Idaho Falls - Located at the INL Research } \\
\text { Center (IRC) facility, south of Building } \\
\text { IF-638 }\end{array}$ \\
\hline 675 & IF-638E O-2 & BEA & $\begin{array}{l}\text { Idaho Falls - Located at the INL Research } \\
\text { Center (IRC) facility, east of Building IF- } \\
638\end{array}$ \\
\hline 680 & VanB O-1 & BEA & $\begin{array}{l}\text { Van Buren Blvd just north of U.S. } \\
\text { Highway } 20 / 26\end{array}$ \\
\hline 682 & EFS O-1 & BEA & $\begin{array}{l}\text { Experimental Field Station - West of } \\
\text { facility fence }\end{array}$ \\
\hline 136 & Reno Ranch & GSS & $\begin{array}{l}\text { Reno Ranch - State HWY } 22 \text { mile marker } \\
41\end{array}$ \\
\hline 137 & Blue Dome & GSS & Blue Dome \\
\hline 138 & Craters of Moon & GSS & Craters of the Moon \\
\hline 139 & Atomic City & GSS & US HWY 26 - South of mile marker 278 \\
\hline 140 & Blackfoot & GSS & Blackfoot \\
\hline 141 & Aberdeen & GSS & Aberdeen \\
\hline 142 & Minidoka & GSS & Minidoka \\
\hline 143 & Roberts & GSS & Roberts \\
\hline 144 & Idaho Falls & GSS & $\begin{array}{l}\text { Idaho Falls - North of TSA/TSB on east } \\
\text { side of Foote Dr. }\end{array}$ \\
\hline 145 & Monteview & GSS & $\begin{array}{l}\text { Monteview - Near intersection of E } 2700 \\
\text { North \& N } 800 \text { East }\end{array}$ \\
\hline 146 & DuBois & GSS & DuBois \\
\hline 147 & Howe & GSS & Howe \\
\hline
\end{tabular}


Table A-12. (continued).

\begin{tabular}{|l|l|l|l|}
\hline EMP_REF_ID & \multicolumn{1}{|c|}{ LOC_NAME } & CON_ID & \multicolumn{1}{c|}{ LOCATION DESCRIPTION } \\
\hline 149 & Arco & GSS & $\begin{array}{l}\text { Arco - NOAA tower 0.5 miles south of } \\
\text { U.S. HWY 20/26 mile marker 249 }\end{array}$ \\
\hline 150 & Mountain View Middle School & GSS & $\begin{array}{l}\text { Blackfoot - Mountain View Middle } \\
\text { School }\end{array}$ \\
\hline 151 & Jackson Hole & GSS & Jackson Hole \\
\hline 659 & Rexburg & GSS & $\begin{array}{l}\text { Rexburg - Behind Madison Middle } \\
\text { School }\end{array}$ \\
\hline 662 & Sugar City & GSS & Sugar City \\
\hline 681 & Main Gate O-1 & GSS & Main Guard Gate \\
\hline
\end{tabular}


Table A-13. Flora and Fauna Surveillance Locations.

\begin{tabular}{|l|l|l|l|}
\hline EMP_REF_ID & \multicolumn{1}{|c|}{ LOC_NAME } & CON_ID & \multicolumn{1}{|c|}{ LOCATION DESCRIPTION } \\
\hline 80 & Industrial Waste Pond (IWP) & GSS & MFC - Industrial Waste Pond \\
\hline 81 & Sanitary Sewage Lagoons & GSS & $\begin{array}{l}\text { MFC -SW Sanitary Sewage Lagoon Pond } \\
\text { (MFC-779) }\end{array}$ \\
\hline 83 & Sewage Lagoons & GSS & $\begin{array}{l}\text { ATR Complex - Main Sewage Lagoon } \\
\text { TRA-736 }\end{array}$ \\
\hline 84 & Sewage Treatment Lagoons & GSS & $\begin{array}{l}\text { INTEC - Cell 2 at Sewage Treatment } \\
\text { Lagoons }\end{array}$ \\
\hline
\end{tabular}


Table A-14. Long-Term Vegetation (GSS).

\begin{tabular}{|c|c|c|c|}
\hline PLOT & MEDIA & PLOT & MEDIA \\
\hline 1 & Long-term vegetation plot & 48 & Long-term vegetation plot \\
\hline 2 & Long-term vegetation plot & 49 & Long-term vegetation plot \\
\hline 3 & Long-term vegetation plot & 50 & Long-term vegetation plot \\
\hline 4 & Long-term vegetation plot & 51 & Long-term vegetation plot \\
\hline 5 & Long-term vegetation plot & 52 & Long-term vegetation plot \\
\hline 6 & Long-term vegetation plot & 53 & Long-term vegetation plot \\
\hline 7 & Long-term vegetation plot & 54 & Long-term vegetation plot \\
\hline 8 & Long-term vegetation plot & 55 & Long-term vegetation plot \\
\hline 9 & Long-term vegetation plot & 56 & Long-term vegetation plot \\
\hline 10 & Long-term vegetation plot & 57 & Long-term vegetation plot \\
\hline 11 & Long-term vegetation plot & 66 & Long-term vegetation plot \\
\hline 13 & Long-term vegetation plot & 67 & Long-term vegetation plot \\
\hline 14 & Long-term vegetation plot & 68 & Long-term vegetation plot \\
\hline 15 & Long-term vegetation plot & 69 & Long-term vegetation plot \\
\hline 17 & Long-term vegetation plot & 70 & Long-term vegetation plot \\
\hline 18 & Long-term vegetation plot & 71 & Long-term vegetation plot \\
\hline 19 & Long-term vegetation plot & 72 & Long-term vegetation plot \\
\hline 20 & Long-term vegetation plot & 73 & Long-term vegetation plot \\
\hline 21 & Long-term vegetation plot & 74 & Long-term vegetation plot \\
\hline 22 & Long-term vegetation plot & 75 & Long-term vegetation plot \\
\hline 23 & Long-term vegetation plot & 76 & Long-term vegetation plot \\
\hline 24 & Long-term vegetation plot & 77 & Long-term vegetation plot \\
\hline 25 & Long-term vegetation plot & 78 & Long-term vegetation plot \\
\hline 26 & Long-term vegetation plot & 79 & Long-term vegetation plot \\
\hline 27 & Long-term vegetation plot & 80 & Long-term vegetation plot \\
\hline 28 & Long-term vegetation plot & 81 & Long-term vegetation plot \\
\hline 29 & Long-term vegetation plot & 82 & Long-term vegetation plot \\
\hline 30 & Long-term vegetation plot & 83 & Long-term vegetation plot \\
\hline 31 & Long-term vegetation plot & 84 & Long-term vegetation plot \\
\hline 32 & Long-term vegetation plot & 85 & Long-term vegetation plot \\
\hline 33 & Long-term vegetation plot & 86 & Long-term vegetation plot \\
\hline
\end{tabular}


Table A-14. (continued).

\begin{tabular}{|l|l|l|l|}
\hline PLOT & \multicolumn{1}{|c|}{ MEDIA } & \multicolumn{1}{|c|}{ PLOT } & \multicolumn{1}{c|}{ MEDIA } \\
\hline 34 & Long-term vegetation plot & 87 & Long-term vegetation plot \\
\hline 35 & Long-term vegetation plot & 88 & Long-term vegetation plot \\
\hline 36 & Long-term vegetation plot & 89 & Long-term vegetation plot \\
\hline 37 & Long-term vegetation plot & 90 & Long-term vegetation plot \\
\hline 38 & Long-term vegetation plot & 91 & Long-term vegetation plot \\
\hline 39 & Long-term vegetation plot & 92 & Long-term vegetation plot \\
\hline 40 & Long-term vegetation plot & 93 & Long-term vegetation plot \\
\hline 42 & Long-term vegetation plot & 94 & Long-term vegetation plot \\
\hline 43 & Long-term vegetation plot & 95 & Long-term vegetation plot \\
\hline 44 & Long-term vegetation plot & 96 & Long-term vegetation plot \\
\hline 45 & Long-term vegetation plot & 98 & Long-term vegetation plot \\
\hline 46 & Long-term vegetation plot & 99 & Long-term vegetation plot \\
\hline 47 & Long-term vegetation plot & & \\
\hline
\end{tabular}


Table A-15. Breeding Bird Routes (GSS).

\begin{tabular}{|c|c|c|c|}
\hline ID & ROUTE_ID & ROUTE_NAME & ROUTE_TYPE \\
\hline 1 & $\mathrm{a}$ & TWIN BUTTES & USGS \\
\hline 2 & $\mathrm{a}$ & TWIN BUTTES & USGS \\
\hline 3 & $\mathrm{a}$ & TWIN BUTTES & USGS \\
\hline 4 & $\mathrm{a}$ & TWIN BUTTES & USGS \\
\hline 5 & $\mathrm{a}$ & TWIN BUTTES & USGS \\
\hline 6 & $\mathrm{a}$ & TWIN BUTTES & USGS \\
\hline 7 & $\mathrm{a}$ & TWIN BUTTES & USGS \\
\hline 8 & $\mathrm{a}$ & TWIN BUTTES & USGS \\
\hline 9 & $\mathrm{a}$ & TWIN BUTTES & USGS \\
\hline 10 & $\mathrm{a}$ & TWIN BUTTES & USGS \\
\hline 11 & $\mathrm{a}$ & TWIN BUTTES & USGS \\
\hline 12 & $\mathrm{a}$ & TWIN BUTTES & USGS \\
\hline 13 & $\mathrm{a}$ & TWIN BUTTES & USGS \\
\hline 14 & $\mathrm{a}$ & TWIN BUTTES & USGS \\
\hline 15 & $\mathrm{a}$ & TWIN BUTTES & USGS \\
\hline 16 & $\mathrm{a}$ & TWIN BUTTES & USGS \\
\hline 17 & $\mathrm{a}$ & TWIN BUTTES & USGS \\
\hline 18 & $\mathrm{a}$ & TWIN BUTTES & USGS \\
\hline 19 & $\mathrm{a}$ & TWIN BUTTES & USGS \\
\hline 20 & $\mathrm{a}$ & TWIN BUTTES & USGS \\
\hline 21 & $\mathrm{a}$ & TWIN BUTTES & USGS \\
\hline 22 & $\mathrm{a}$ & TWIN BUTTES & USGS \\
\hline 23 & $\mathrm{a}$ & TWIN BUTTES & USGS \\
\hline 24 & $\mathrm{a}$ & TWIN BUTTES & USGS \\
\hline 25 & $\mathrm{a}$ & TWIN BUTTES & USGS \\
\hline 26 & $\mathrm{a}$ & TWIN BUTTES & USGS \\
\hline 27 & $\mathrm{a}$ & TWIN BUTTES & USGS \\
\hline 28 & $\mathrm{a}$ & TWIN BUTTES & USGS \\
\hline 29 & $\mathrm{a}$ & TWIN BUTTES & USGS \\
\hline 30 & $\mathrm{a}$ & TWIN BUTTES & USGS \\
\hline 31 & $\mathrm{a}$ & TWIN BUTTES & USGS \\
\hline
\end{tabular}


Table A-15. (continued).

\begin{tabular}{|c|c|c|c|}
\hline \\
\hline ID & ROUTE_ID & ROUTE_NAME & ROUTE_TYPE \\
\hline 32 & $\mathrm{a}$ & TWIN BUTTES & USGS \\
\hline 33 & $\mathrm{a}$ & TWIN BUTTES & USGS \\
\hline 34 & $\mathrm{a}$ & TWIN BUTTES & USGS \\
\hline 35 & $\mathrm{a}$ & TWIN BUTTES & USGS \\
\hline 36 & $\mathrm{a}$ & TWIN BUTTES & USGS \\
\hline 37 & $\mathrm{a}$ & TWIN BUTTES & USGS \\
\hline 38 & $\mathrm{a}$ & TWIN BUTTES & USGS \\
\hline 39 & $\mathrm{a}$ & TWIN BUTTES & USGS \\
\hline 40 & $\mathrm{a}$ & TWIN BUTTES & USGS \\
\hline 41 & $\mathrm{a}$ & TWIN BUTTES & USGS \\
\hline 42 & $\mathrm{a}$ & TWIN BUTTES & USGS \\
\hline 43 & $\mathrm{a}$ & TWIN BUTTES & USGS \\
\hline 44 & $\mathrm{a}$ & TWIN BUTTES & USGS \\
\hline 45 & $\mathrm{a}$ & TWIN BUTTES & USGS \\
\hline 46 & $\mathrm{a}$ & TWIN BUTTES & USGS \\
\hline 47 & $\mathrm{a}$ & TWIN BUTTES & USGS \\
\hline 48 & $\mathrm{a}$ & TWIN BUTTES & USGS \\
\hline 49 & $\mathrm{a}$ & TWIN BUTTES & USGS \\
\hline 50 & $\mathrm{a}$ & TWIN BUTTES & USGS \\
\hline 1 & $\mathrm{~b}$ & LOST RIVER & USGS \\
\hline 2 & $\mathrm{~b}$ & LOST RIVER & USGS \\
\hline 3 & $\mathrm{~b}$ & LOST RIVER & USGS \\
\hline 4 & $\mathrm{~b}$ & LOST RIVER & USGS \\
\hline 5 & $\mathrm{~b}$ & LOST RIVER & USGS \\
\hline 6 & $\mathrm{~b}$ & LOST RIVER & USGS \\
\hline 7 & $\mathrm{~b}$ & LOST RIVER & USGS \\
\hline 8 & $\mathrm{~b}$ & LOST RIVER & USGS \\
\hline 9 & $\mathrm{~b}$ & LOST RIVER & USGS \\
\hline 10 & $\mathrm{~b}$ & LOST RIVER & USGS \\
\hline 11 & $\mathrm{~b}$ & LOST RIVER & USGS \\
\hline 12 & $\mathrm{~b}$ & LOST RIVER & USGS \\
\hline 13 & $\mathrm{~b}$ & LOST RIVER & USGS \\
\hline
\end{tabular}


Table A-15. (continued).

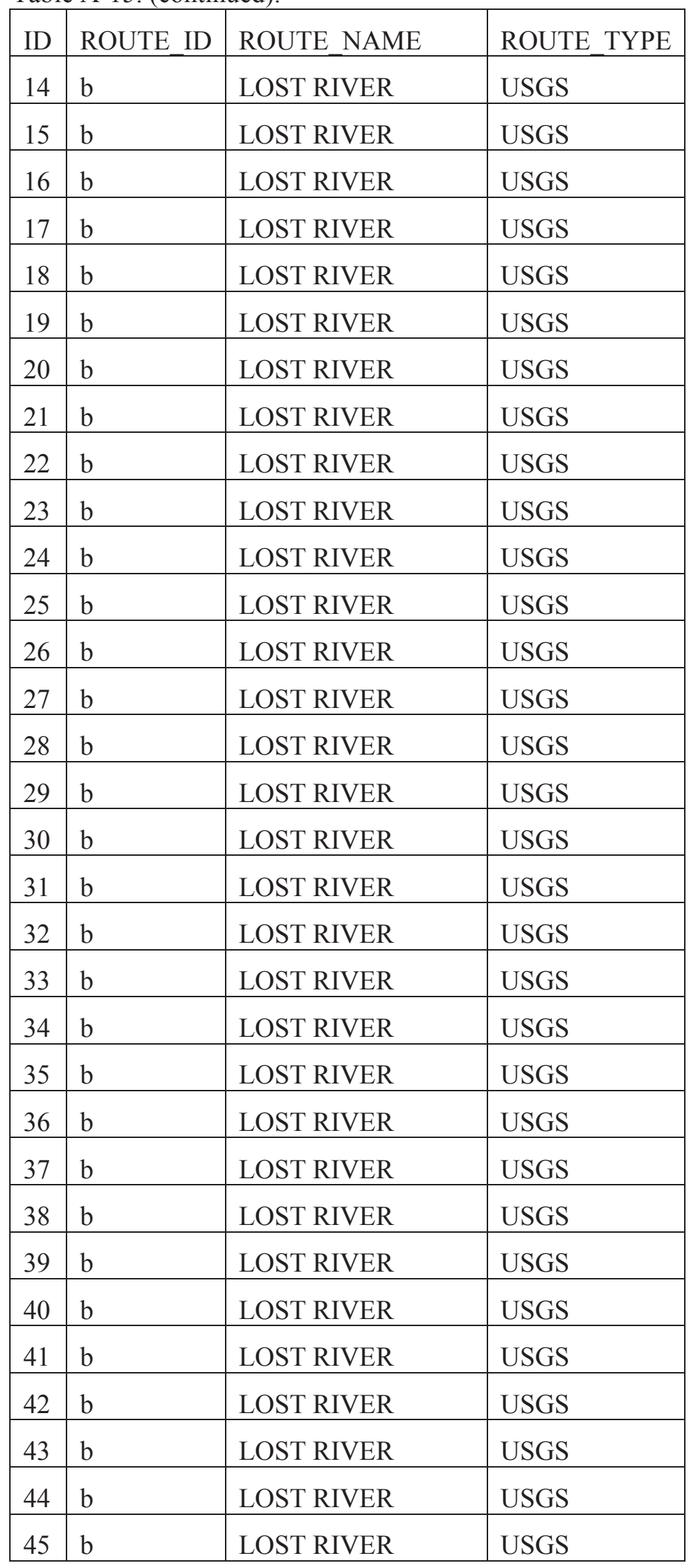


Table A-15. (continued).

\begin{tabular}{|c|c|c|c|}
\hline ID & ROUTE_ID & ROUTE_NAME & ROUTE_TYPE \\
\hline 46 & $\mathrm{~b}$ & LOST RIVER & USGS \\
\hline 47 & $\mathrm{~b}$ & LOST RIVER & USGS \\
\hline 48 & $\mathrm{~b}$ & LOST RIVER & USGS \\
\hline 49 & $\mathrm{~b}$ & LOST RIVER & USGS \\
\hline 50 & $\mathrm{~b}$ & LOST RIVER & USGS \\
\hline 1 & $\mathrm{c}$ & KYLE CANYON & USGS \\
\hline 2 & $\mathrm{c}$ & KYLE CANYON & USGS \\
\hline 3 & $\mathrm{c}$ & KYLE CANYON & USGS \\
\hline 4 & $\mathrm{c}$ & KYLE CANYON & USGS \\
\hline 5 & $\mathrm{c}$ & KYLE CANYON & USGS \\
\hline 6 & $\mathrm{c}$ & KYLE CANYON & USGS \\
\hline 7 & $\mathrm{c}$ & KYLE CANYON & USGS \\
\hline 8 & $\mathrm{c}$ & KYLE CANYON & USGS \\
\hline 9 & $\mathrm{c}$ & KYLE CANYON & USGS \\
\hline 10 & $\mathrm{c}$ & KYLE CANYON & USGS \\
\hline 11 & $\mathrm{c}$ & KYLE CANYON & USGS \\
\hline 12 & $\mathrm{c}$ & KYLE CANYON & USGS \\
\hline 13 & $\mathrm{c}$ & KYLE CANYON & USGS \\
\hline 14 & $\mathrm{c}$ & KYLE CANYON & USGS \\
\hline 15 & $\mathrm{c}$ & KYLE CANYON & USGS \\
\hline 16 & $\mathrm{c}$ & KYLE CANYON & USGS \\
\hline 17 & $\mathrm{c}$ & KYLE CANYON & USGS \\
\hline 18 & $\mathrm{c}$ & KYLE CANYON & USGS \\
\hline 19 & $\mathrm{c}$ & KYLE CANYON & USGS \\
\hline 20 & $\mathrm{c}$ & KYLE CANYON & USGS \\
\hline 21 & $\mathrm{c}$ & KYLE CANYON & USGS \\
\hline 22 & $\mathrm{c}$ & KYLE CANYON & USGS \\
\hline 23 & $\mathrm{c}$ & KYLE CANYON & USGS \\
\hline 24 & $\mathrm{c}$ & KYLE CANYON & USGS \\
\hline 25 & $\mathrm{c}$ & KYLE CANYON & USGS \\
\hline 26 & $\mathrm{c}$ & KYLE CANYON & USGS \\
\hline 27 & $\mathrm{c}$ & KYLE CANYON & USGS \\
\hline
\end{tabular}


Table A-15. (continued).

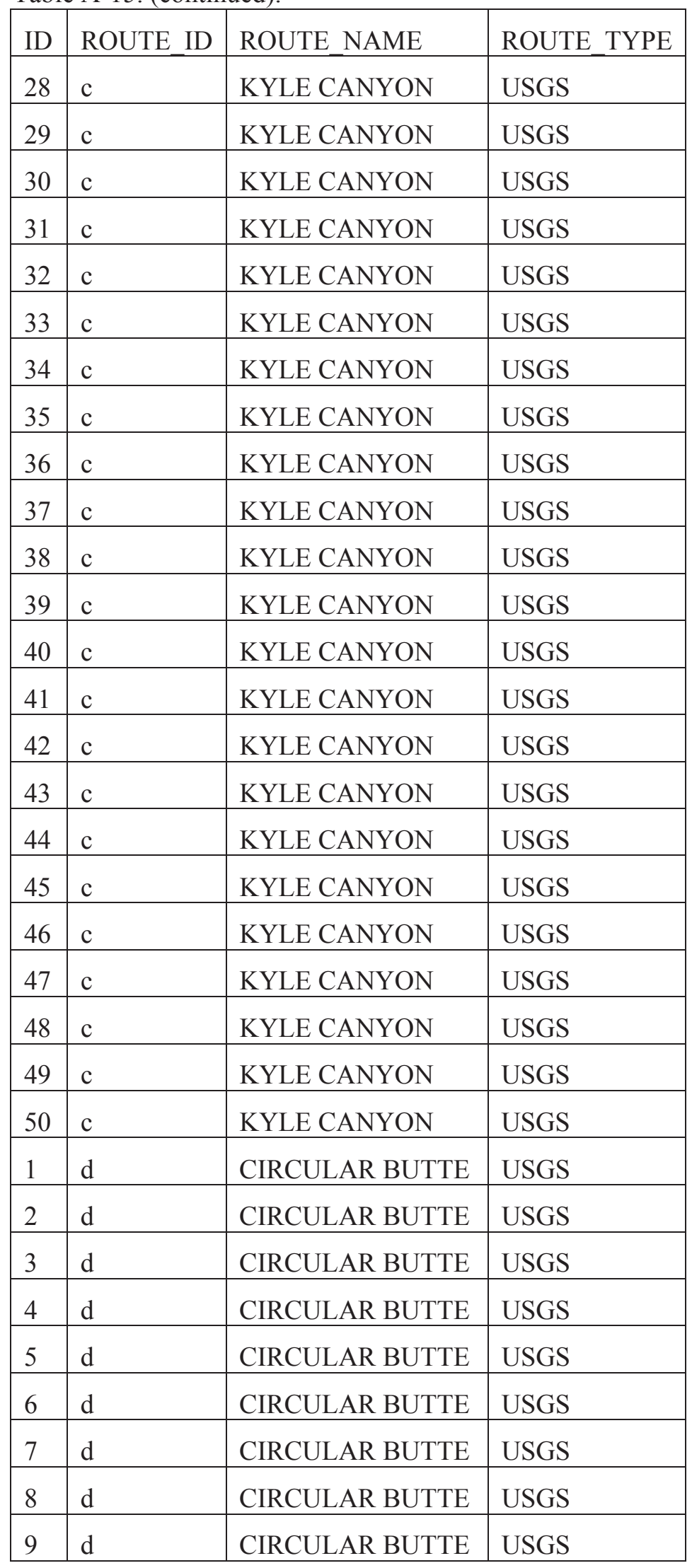


Table A-15. (continued).

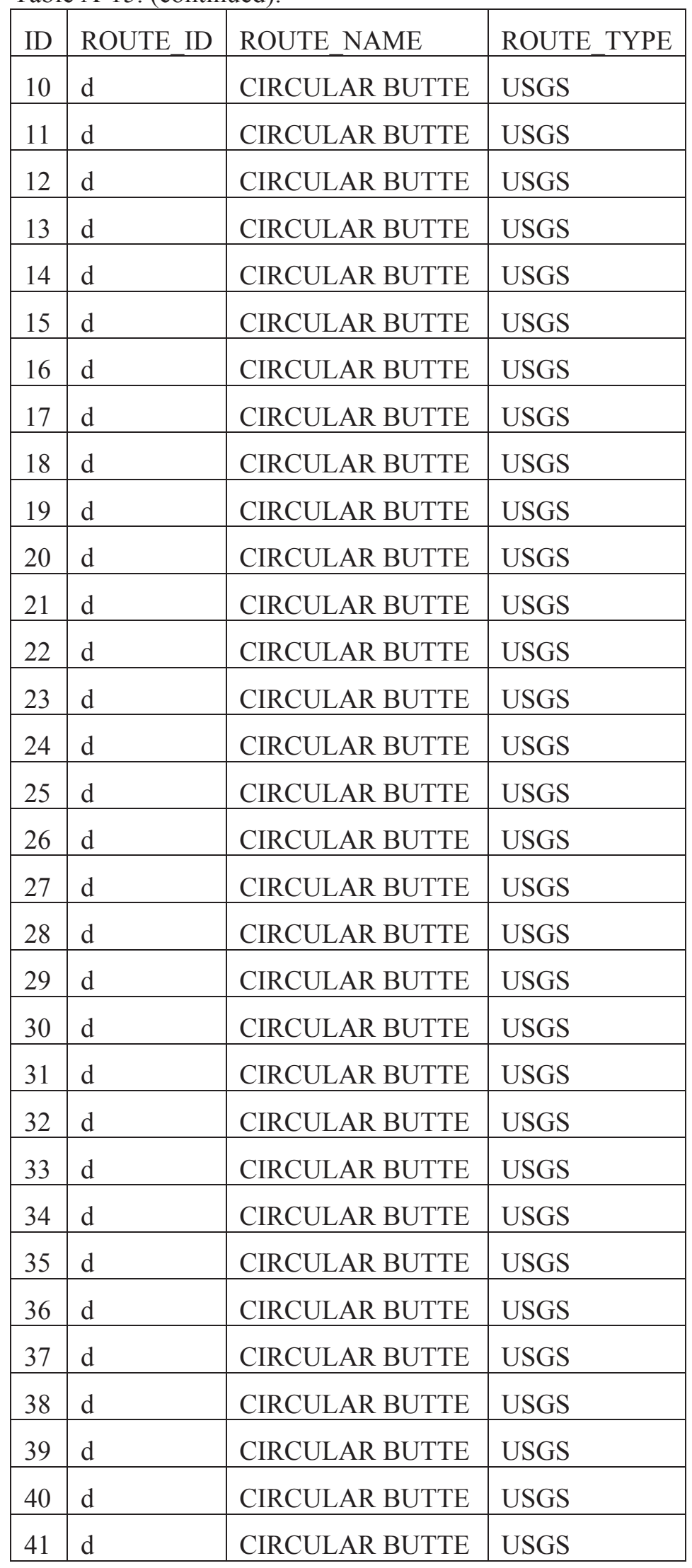


Table A-15. (continued).

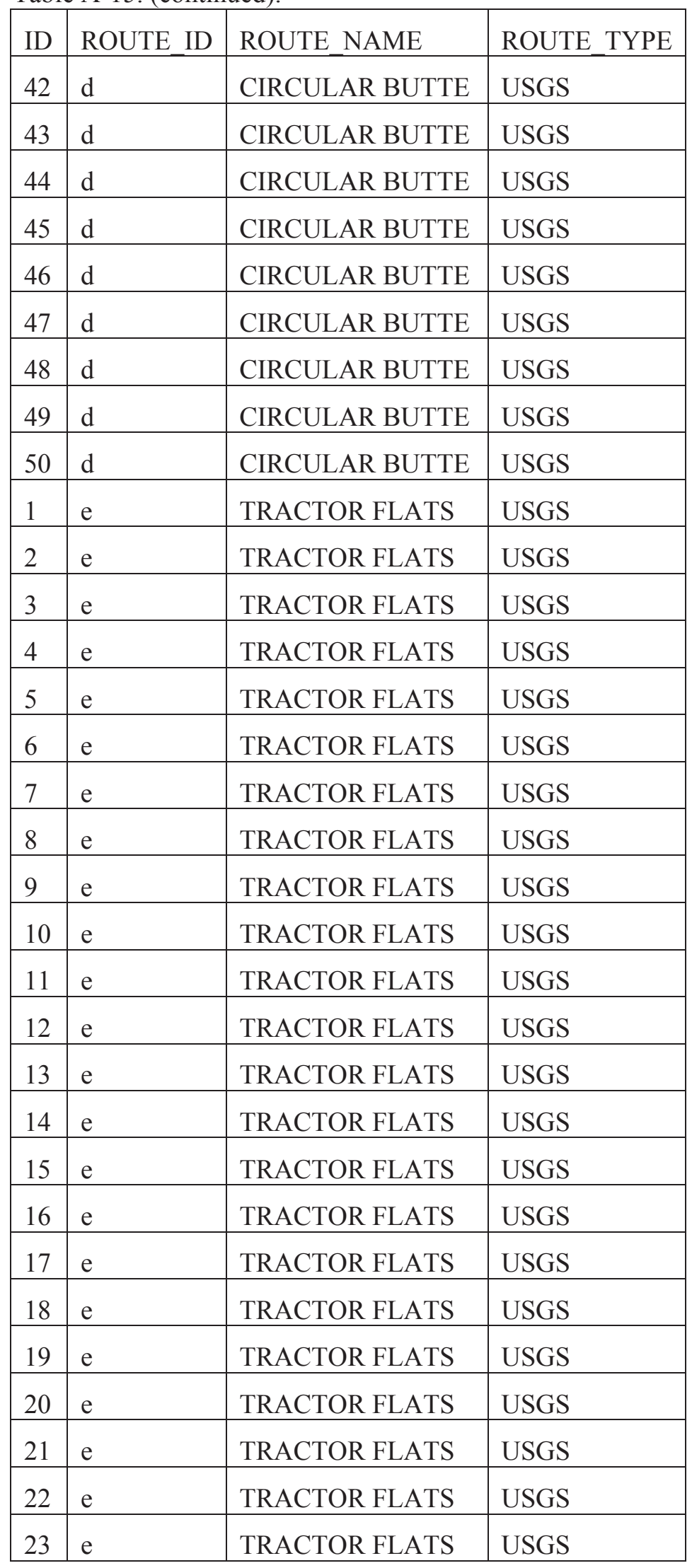


Table A-15. (continued).

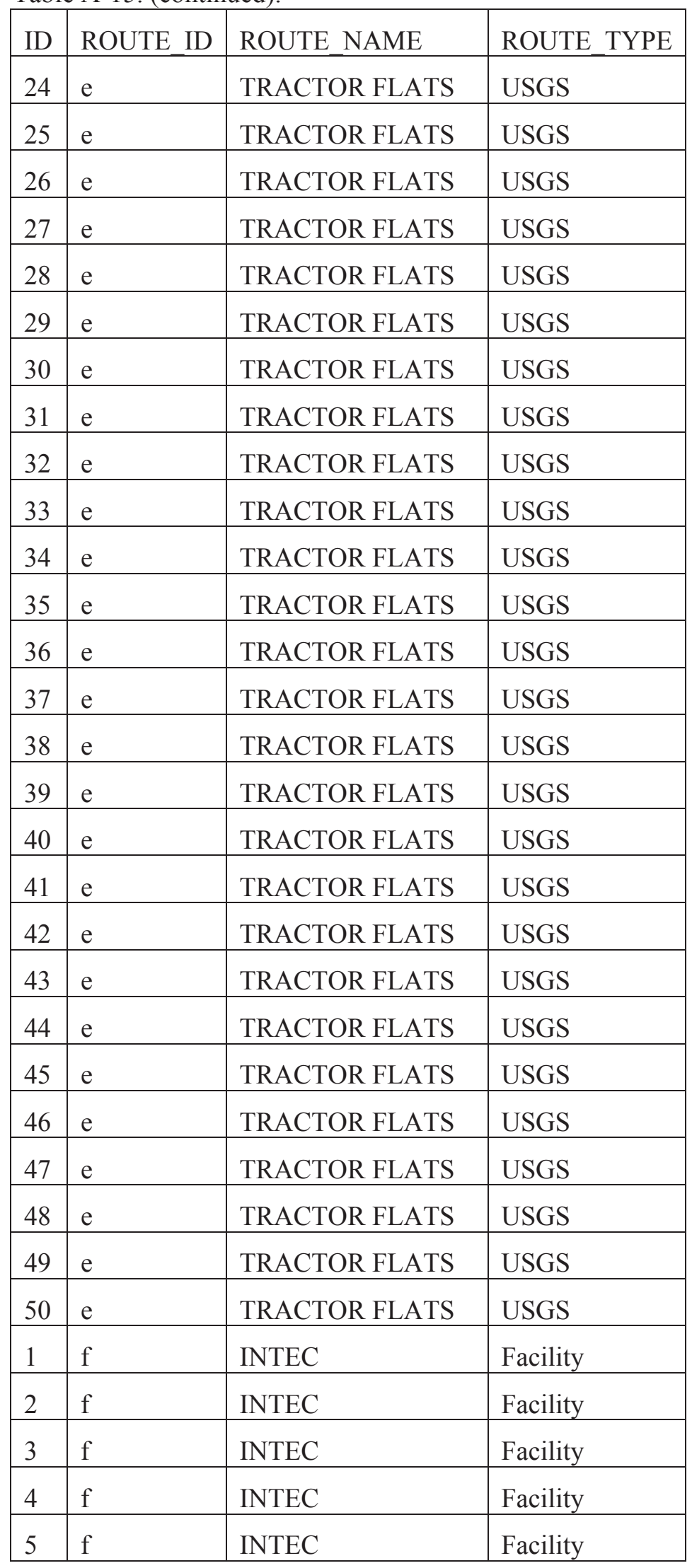


Table A-15. (continued).

\begin{tabular}{|c|c|c|c|}
\hline & & & \\
\hline ID & ROUTE_ID & ROUTE_NAME & ROUTE_TYPE \\
\hline 6 & $\mathrm{f}$ & INTEC & Facility \\
\hline 7 & $\mathrm{f}$ & INTEC & Facility \\
\hline 8 & $\mathrm{f}$ & INTEC & Facility \\
\hline 9 & $\mathrm{f}$ & INTEC & Facility \\
\hline 10 & $\mathrm{f}$ & INTEC & Facility \\
\hline 11 & $\mathrm{f}$ & INTEC & Facility \\
\hline 12 & $\mathrm{f}$ & INTEC & Facility \\
\hline 13 & $\mathrm{f}$ & INTEC & Facility \\
\hline 14 & $\mathrm{f}$ & INTEC & Facility \\
\hline 15 & $\mathrm{f}$ & INTEC & Facility \\
\hline 16 & $\mathrm{f}$ & INTEC & Facility \\
\hline 17 & $\mathrm{f}$ & INTEC & Facility \\
\hline 18 & $\mathrm{f}$ & INTEC & Facility \\
\hline 19 & $\mathrm{f}$ & INTEC & Facility \\
\hline 20 & $\mathrm{f}$ & INTEC & Facility \\
\hline 21 & $\mathrm{f}$ & INTEC & Facility \\
\hline 22 & $\mathrm{f}$ & INTEC & Facility \\
\hline 23 & $\mathrm{f}$ & INTEC & Facility \\
\hline 24 & $\mathrm{f}$ & INTEC & Facility \\
\hline 25 & $\mathrm{f}$ & INTEC & Facility \\
\hline 1 & $\mathrm{~g}$ & ATRC & Facility \\
\hline 2 & $\mathrm{~g}$ & ATRC & Facility \\
\hline 3 & $\mathrm{~g}$ & ATRC & Facility \\
\hline 4 & $\mathrm{~g}$ & ATRC & Facility \\
\hline 5 & $\mathrm{~g}$ & ATRC & Facility \\
\hline 6 & $\mathrm{~g}$ & ATRC & Facility \\
\hline 7 & $\mathrm{~g}$ & ATRC & Facility \\
\hline 8 & $\mathrm{~g}$ & ATRC & Facility \\
\hline 9 & $\mathrm{~g}$ & ATRC & Facility \\
\hline 10 & $\mathrm{~g}$ & ATRC & Facility \\
\hline 11 & $\mathrm{~g}$ & ATRC & Facility \\
\hline 12 & $\mathrm{~g}$ & ATRC & Facility \\
\hline
\end{tabular}


Table A-15. (continued).

\begin{tabular}{|c|c|c|c|}
\hline & & & \\
\hline ID & ROUTE_ID & ROUTE_NAME & ROUTE_TYPE \\
\hline 13 & $\mathrm{~g}$ & ATRC & Facility \\
\hline 14 & $\mathrm{~g}$ & ATRC & Facility \\
\hline 15 & $\mathrm{~g}$ & ATRC & Facility \\
\hline 16 & $\mathrm{~g}$ & ATRC & Facility \\
\hline 17 & $\mathrm{~g}$ & ATRC & Facility \\
\hline 18 & $\mathrm{~g}$ & ATRC & Facility \\
\hline 19 & $\mathrm{~g}$ & ATRC & Facility \\
\hline 20 & $\mathrm{~g}$ & ATRC & Facility \\
\hline 21 & $\mathrm{~g}$ & ATRC & Facility \\
\hline 22 & $\mathrm{~g}$ & ATRC & Facility \\
\hline 23 & $\mathrm{~g}$ & ATRC & Facility \\
\hline 24 & $\mathrm{~g}$ & ATRC & Facility \\
\hline 25 & $\mathrm{~g}$ & ATRC & Facility \\
\hline 26 & $\mathrm{~g}$ & ATRC & Facility \\
\hline 27 & $\mathrm{~g}$ & ATRC & Facility \\
\hline 28 & $\mathrm{~g}$ & ATRC & Facility \\
\hline 29 & $\mathrm{~g}$ & ATRC & Facility \\
\hline 30 & $\mathrm{~g}$ & ATRC & Facility \\
\hline 31 & $\mathrm{~g}$ & ATRC & Facility \\
\hline 32 & $\mathrm{~g}$ & ATRC & Facility \\
\hline 1 & $\mathrm{~h}$ & CFA & Facility \\
\hline 2 & $\mathrm{~h}$ & CFA & Facility \\
\hline 3 & $\mathrm{~h}$ & CFA & Facility \\
\hline 4 & $\mathrm{~h}$ & CFA & Facility \\
\hline 5 & $\mathrm{~h}$ & CFA & Facility \\
\hline 6 & $\mathrm{~h}$ & CFA & Facility \\
\hline 7 & $\mathrm{~h}$ & CFA & Facility \\
\hline 8 & $\mathrm{~h}$ & CFA & Facility \\
\hline 9 & $\mathrm{~h}$ & CFA & Facility \\
\hline 10 & $\mathrm{~h}$ & CFA & Facility \\
\hline 11 & $\mathrm{~h}$ & CFA & Facility \\
\hline 12 & $\mathrm{~h}$ & CFA & Facility \\
\hline
\end{tabular}


Table A-15. (continued).

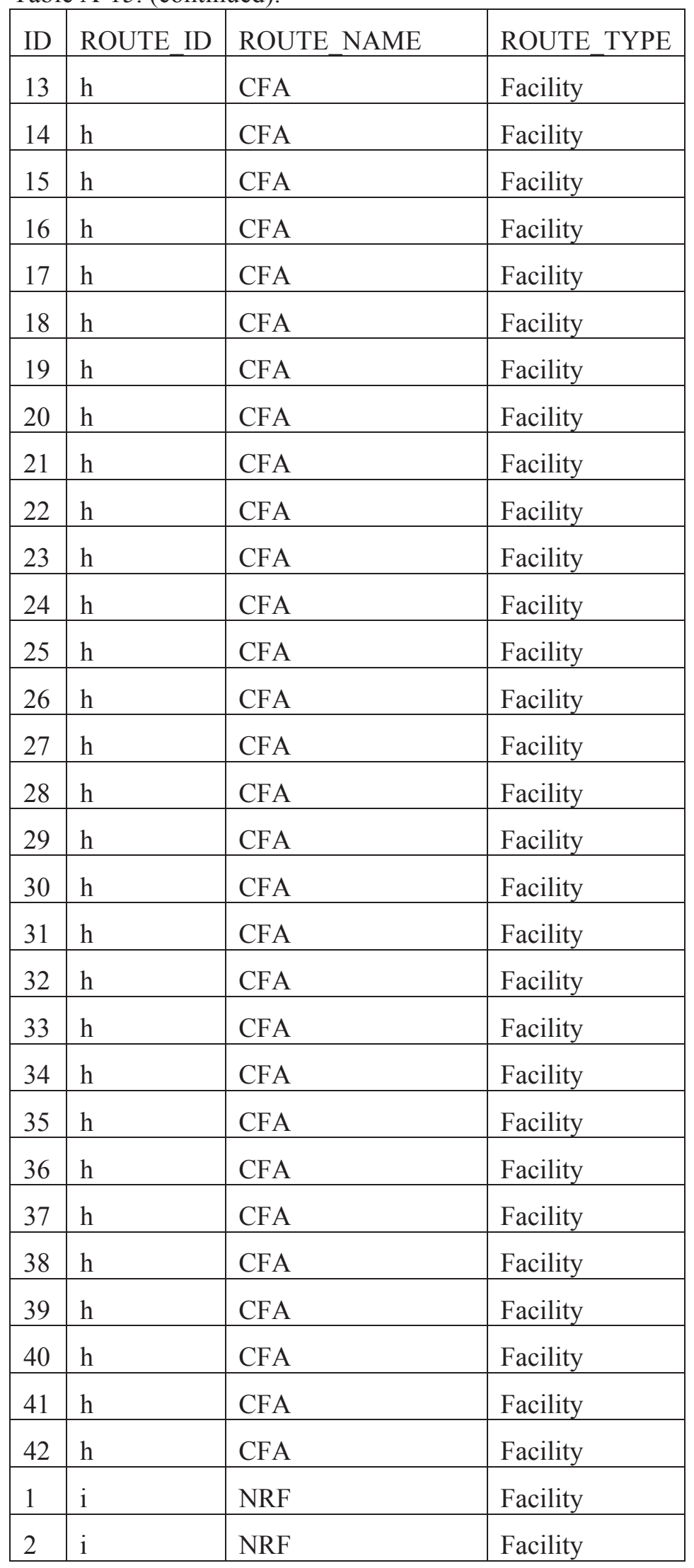


Table A-15. (continued).

\begin{tabular}{|c|c|c|c|}
\hline & & & \\
\hline ID & ROUTE_ID & ROUTE_NAME & ROUTE_TYPE \\
\hline 3 & $\mathrm{i}$ & NRF & Facility \\
\hline 4 & $\mathrm{i}$ & NRF & Facility \\
\hline 5 & $\mathrm{i}$ & $\mathrm{NRF}$ & Facility \\
\hline 6 & $\mathrm{i}$ & NRF & Facility \\
\hline 7 & $\mathrm{i}$ & NRF & Facility \\
\hline 8 & $\mathrm{i}$ & NRF & Facility \\
\hline 9 & $\mathrm{i}$ & NRF & Facility \\
\hline 10 & $\mathrm{i}$ & $\mathrm{NRF}$ & Facility \\
\hline 11 & $\mathrm{i}$ & NRF & Facility \\
\hline 12 & $\mathrm{i}$ & $\mathrm{NRF}$ & Facility \\
\hline 13 & $\mathrm{i}$ & $\mathrm{NRF}$ & Facility \\
\hline 14 & $\mathrm{i}$ & $\mathrm{NRF}$ & Facility \\
\hline 15 & $\mathrm{i}$ & NRF & Facility \\
\hline 16 & $\mathrm{i}$ & $\mathrm{NRF}$ & Facility \\
\hline 17 & $\mathrm{i}$ & $\mathrm{NRF}$ & Facility \\
\hline 18 & $\mathrm{i}$ & $\mathrm{NRF}$ & Facility \\
\hline 19 & $\mathrm{i}$ & $\mathrm{NRF}$ & Facility \\
\hline 20 & $\mathrm{i}$ & NRF & Facility \\
\hline 1 & $\mathrm{j}$ & TAN & Facility \\
\hline 2 & $\mathrm{j}$ & TAN & Facility \\
\hline 3 & $\mathrm{j}$ & TAN & Facility \\
\hline 4 & $\mathrm{j}$ & TAN & Facility \\
\hline 5 & $\mathrm{j}$ & TAN & Facility \\
\hline 6 & $\mathrm{j}$ & TAN & Facility \\
\hline 7 & $\mathrm{j}$ & TAN & Facility \\
\hline 8 & $\mathrm{j}$ & TAN & Facility \\
\hline 9 & $\mathrm{j}$ & TAN & Facility \\
\hline 10 & $\mathrm{j}$ & TAN & Facility \\
\hline 11 & $\mathrm{j}$ & TAN & Facility \\
\hline 12 & $\mathrm{j}$ & TAN & Facility \\
\hline 13 & $\mathrm{j}$ & TAN & Facility \\
\hline 14 & $\mathrm{j}$ & TAN & Facility \\
\hline
\end{tabular}


Table A-15. (continued).

\begin{tabular}{|c|c|c|c|}
\hline & & & \\
\hline ID & ROUTE_ID & ROUTE_NAME & ROUTE_TYPE \\
\hline 15 & $\mathrm{j}$ & TAN & Facility \\
\hline 16 & $\mathrm{j}$ & TAN & Facility \\
\hline 17 & $\mathrm{j}$ & TAN & Facility \\
\hline 18 & $\mathrm{j}$ & TAN & Facility \\
\hline 19 & $\mathrm{j}$ & TAN & Facility \\
\hline 20 & $\mathrm{j}$ & TAN & Facility \\
\hline 21 & $\mathrm{j}$ & TAN & Facility \\
\hline 22 & $\mathrm{j}$ & TAN & Facility \\
\hline 23 & $\mathrm{j}$ & TAN & Facility \\
\hline 24 & $\mathrm{j}$ & TAN & Facility \\
\hline 25 & $\mathrm{j}$ & TAN & Facility \\
\hline 26 & $\mathrm{j}$ & TAN & Facility \\
\hline 27 & $\mathrm{j}$ & TAN & Facility \\
\hline 28 & $\mathrm{j}$ & TAN & Facility \\
\hline 29 & $\mathrm{j}$ & TAN & Facility \\
\hline 30 & $\mathrm{j}$ & TAN & Facility \\
\hline 31 & $\mathrm{j}$ & TAN & Facility \\
\hline 32 & $\mathrm{j}$ & TAN & Facility \\
\hline 33 & $\mathrm{j}$ & TAN & Facility \\
\hline 34 & $\mathrm{j}$ & TAN & Facility \\
\hline 35 & $\mathrm{j}$ & TAN & Facility \\
\hline 36 & $\mathrm{j}$ & TAN & Facility \\
\hline 37 & $\mathrm{j}$ & TAN & Facility \\
\hline 38 & $\mathrm{j}$ & TAN & Facility \\
\hline 39 & $\mathrm{j}$ & TAN & Facility \\
\hline 40 & $\mathrm{j}$ & TAN & Facility \\
\hline 41 & $\mathrm{j}$ & TAN & Facility \\
\hline 42 & $\mathrm{j}$ & TAN & Facility \\
\hline 43 & $\mathrm{j}$ & TAN & Facility \\
\hline 44 & $\mathrm{j}$ & TAN & Facility \\
\hline 45 & $\mathrm{j}$ & TAN & Facility \\
\hline 46 & $\mathrm{j}$ & TAN & Facility \\
\hline
\end{tabular}


Table A-15. (continued).

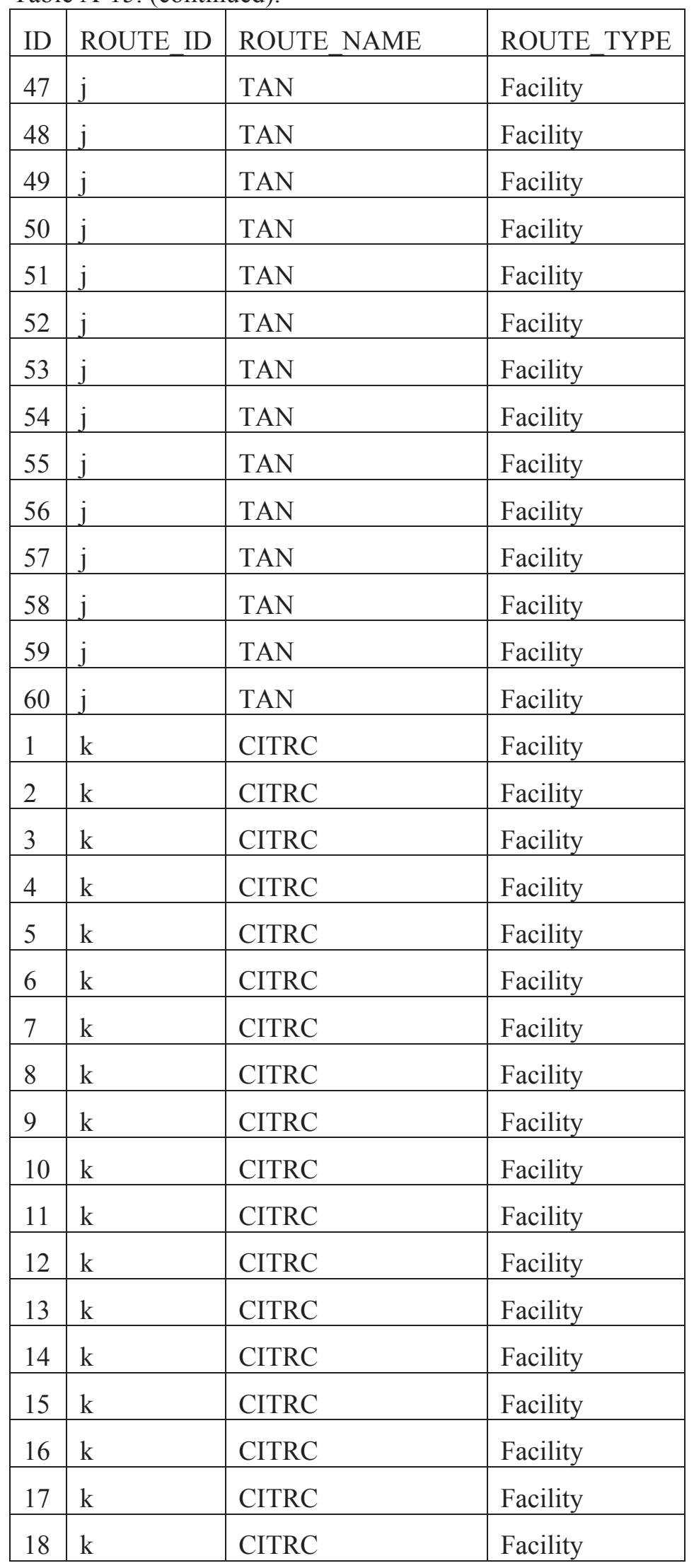


Table A-15. (continued).

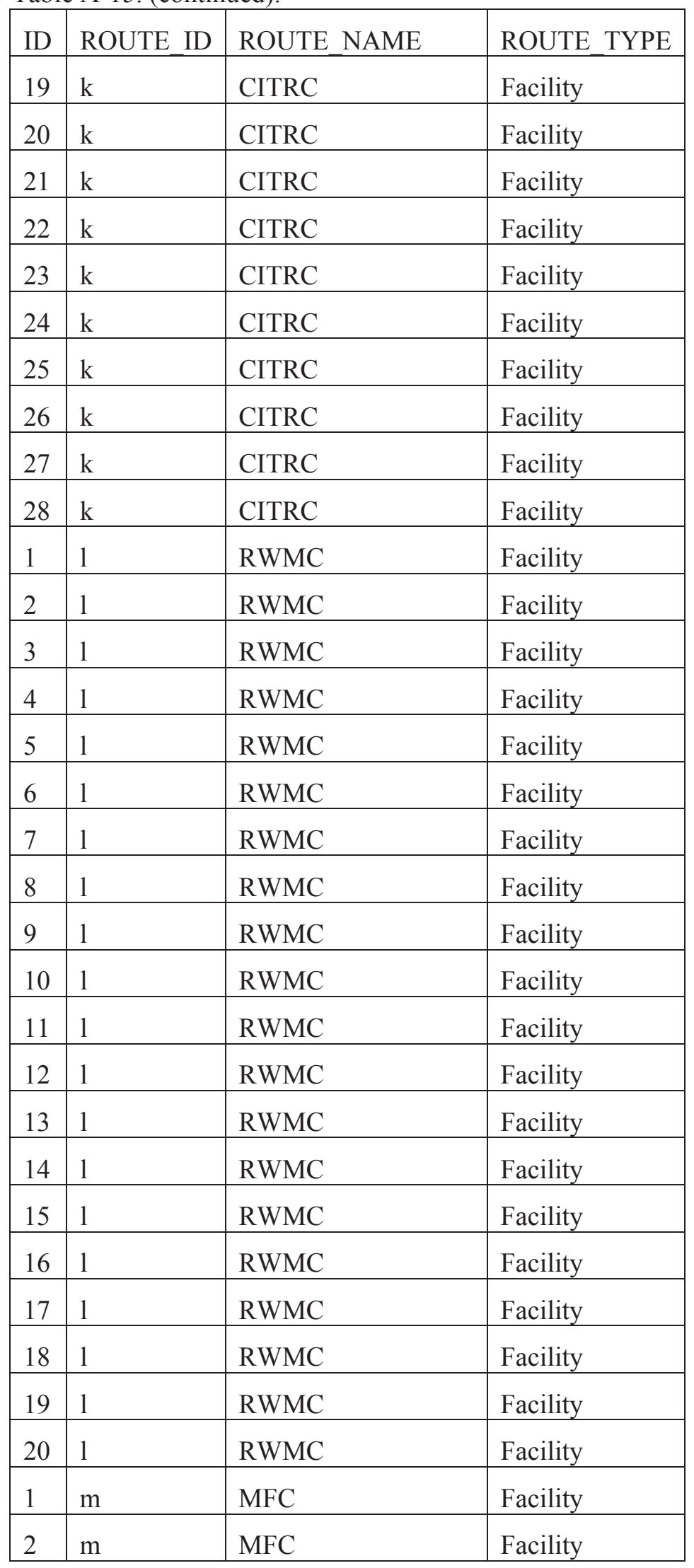


Table A-15. (continued).

\begin{tabular}{|l|l|l|l|}
\hline ID & ROUTE_ID & ROUTE_NAME & ROUTE_TYPE \\
\hline 3 & $\mathrm{~m}$ & MFC & Facility \\
\hline 4 & $\mathrm{~m}$ & MFC & Facility \\
\hline 5 & $\mathrm{~m}$ & MFC & Facility \\
\hline 6 & $\mathrm{~m}$ & MFC & Facility \\
\hline 7 & $\mathrm{~m}$ & MFC & Facility \\
\hline 8 & $\mathrm{~m}$ & MFC & Facility \\
\hline 9 & $\mathrm{~m}$ & MFC & Facility \\
\hline 10 & $\mathrm{~m}$ & MFC & Facility \\
\hline 11 & $\mathrm{~m}$ & MFC & Facility \\
\hline 12 & $\mathrm{~m}$ & MFC & Facility \\
\hline 13 & $\mathrm{~m}$ & MFC & Facility \\
\hline 14 & $\mathrm{~m}$ & MFC & Facility \\
\hline 15 & $\mathrm{~m}$ & MFC & Facility \\
\hline 16 & $\mathrm{~m}$ & MFC & Facility \\
\hline 17 & $\mathrm{~m}$ & MFC & Facility \\
\hline 18 & $\mathrm{~m}$ & MFC & Facility \\
\hline
\end{tabular}


Table A-16. Precipitation Surveillance Locations.

\begin{tabular}{|l|l|l|l|}
\hline EMP_REF_ID & LOC_NAME & CON_ID & LOCATION DESCRIPTION \\
\hline 262 & EFS & GSS & Experimental Field Station - West of facility fence \\
\hline 653 & CFA & GSS & CFA north of Building 690 \\
\hline 676 & Idaho Falls & GSS & Idaho Falls - North of TSA/TSB on east side of Foote Rd. \\
\hline
\end{tabular}


Table A-17. Meteorological Monitoring Locations.

\begin{tabular}{|c|c|c|c|}
\hline EMP_REF_ID & LOC_NAME & CON_ID & LOCATION DESCRIPTION \\
\hline 225 & 690 & NOAA & CFA north of Building 690 \\
\hline 226 & $\mathrm{ABE}$ & NOAA & Aberdeen \\
\hline 227 & $\mathrm{ARC}$ & NOAA & $\begin{array}{l}\text { Arco - NOAA tower } 0.5 \text { miles south of U.S. HWY } 20 / 26 \\
\text { mile marker } 249\end{array}$ \\
\hline 228 & BAS & NOAA & Base of Howe Peak NOAA tower northwest of NRF \\
\hline 229 & BIG & NOAA & Southwest of Big Southern Butte $\sim 10$ miles (Coxs Well) \\
\hline 230 & BLK & NOAA & Blackfoot - Mountain View Middle School \\
\hline 231 & $\mathrm{BLU}$ & NOAA & Blue Dome \\
\hline 232 & CRA & NOAA & Craters of the Moon \\
\hline 233 & DEA & NOAA & Dead Man Canyon NOAA tower on T-Road 11 \\
\hline 234 & DUB & NOAA & Dubois \\
\hline 235 & EBR & NOAA & MFC - West side of MFC facility fence \\
\hline 236 & FOR & NOAA & Fort Hall \\
\hline 237 & GRI & NOAA & INTEC/Grid3 NOAA tower \\
\hline 238 & HAM & NOAA & Hamer \\
\hline 239 & HOW & NOAA & Howe \\
\hline 240 & IDA & NOAA & Idaho Falls south of John's Hole Bridge \\
\hline 241 & KET & NOAA & Kettle Butte \\
\hline 242 & LOF & NOAA & TAN/SMC - North of SMC facility fence at NOAA tower \\
\hline 243 & LOS & NOAA & Big Lost River Rest Area on U.S. Highway 20/26 \\
\hline 244 & MIN & NOAA & Minidoka \\
\hline 245 & MON & NOAA & $\begin{array}{l}\text { Monteview - Near intersection of E } 2700 \text { North \& N } 800 \\
\text { East }\end{array}$ \\
\hline 246 & NRF & NOAA & East of NRF \\
\hline 247 & PBF & NOAA & CITRC at PBF Support Area \\
\hline 248 & PRO & NOAA & 0.5 miles northeast of INTEC/Grid 3 NOAA tower \\
\hline 249 & RIC & NOAA & Richfield \\
\hline 250 & $\mathrm{ROB}$ & NOAA & Roberts - at NOAA tower \\
\hline 251 & ROV & NOAA & Rover NOAA tower on T-Road 4 \\
\hline 252 & RWM & NOAA & North of RWMC \\
\hline 254 & SAN & NOAA & $\begin{array}{l}\text { Sand Dunes NOAA tower - South of Lincoln Blvd. guard } \\
\text { gate \#4 }\end{array}$ \\
\hline 255 & SUG & NOAA & Sugar City \\
\hline
\end{tabular}


Table A-17. (continued).

\begin{tabular}{|l|l|l|l|}
\hline EMP_REF_ID & LOC_NAME & CON_ID & \multicolumn{1}{c|}{ LOCATION DESCRIPTION } \\
\hline 256 & SUM & NOAA & Big Southern Summit \\
\hline 257 & TAB & NOAA & Taber \\
\hline 258 & TER & NOAA & Terreton - State HWY 33 east of mile marker 47 \\
\hline 259 & TRA & NOAA & ATR Complex - West of facility fence \\
\hline 654 & ATO & NOAA & Atomic City at NOAA tower \\
\hline
\end{tabular}


Table A-18. Event Monitoring Locations.

\begin{tabular}{|l|l|l|l|}
\hline EMP_REF_ID & LOC_NAME & CON_ID & \multicolumn{1}{c|}{ LOCATION DESCRIPTION } \\
\hline 120 & 690 & BEA & CFA north of Building 690 \\
\hline 121 & EBR & BEA & MFC - West side of MFC facility fence \\
\hline 122 & LOF & BEA & $\begin{array}{l}\text { TAN/SMC - North of SMC facility fence at } \\
\text { NOAA tower }\end{array}$ \\
\hline 123 & NRF & BEA & East of NRF \\
\hline 124 & PBF & BEA & CITRC at PBF Support Area \\
\hline 125 & RWM & BEA & North of RWMC \\
\hline 126 & GRI & BEA & ATR Complex - West of facility fence \\
\hline 127 & ARC & BEA & $\begin{array}{l}\text { Arco - NOAA tower 0.5 miles south of U.S. HWY } \\
\text { 20/26 mile marker 249 }\end{array}$ \\
\hline 128 & ATO & BEA & Atomic City at NOAA tower \\
\hline 129 & BLU & BEA & Blue Dome \\
\hline 130 & HOW & BEA & Howe \\
\hline 131 & KET & BEA & Kettle Butte \\
\hline 132 & MON & BEA & $\begin{array}{l}\text { Monteview - Near intersection of E 2700 North \& } \\
\text { N 800 East }\end{array}$ \\
\hline 133 & TER & BEA & Terreton - State HWY 33 east of mile marker 47 \\
\hline 134 & IDA & BEA & Idaho Falls south of John's Hole Bridge \\
\hline 135 & RXB & BEA & Rexburg - Behind Madison Middle School \\
\hline
\end{tabular}

